\title{
Pathogenic Pathways and Therapeutic Approaches Targeting Inflammation in Diabetic Nephropathy
}

\author{
Sandra Rayego-Mateos ${ }^{1, *}$, José Luis Morgado-Pascual ${ }^{2}$, Lucas Opazo-Ríos 2,3(1), \\ Melania Guerrero-Hue ${ }^{1}$, Cristina García-Caballero ${ }^{1}$, Cristina Vázquez-Carballo ${ }^{2}$, \\ Sebastián Mas 2,3, Ana Belén Sanz ${ }^{2}$, Carmen Herencia ${ }^{2}$, Sergio Mezzano ${ }^{4}$, \\ Carmen Gómez-Guerrero $2,3\left(\mathbb{1}\right.$, Juan Antonio Moreno ${ }^{1,5,6, *,+}+\mathbb{C}$ and Jesús Egido $2,3,+$ \\ 1 Maimonides Biomedical Research Institute of Cordoba (IMIBIC), University of Cordoba, 14004 Cordoba, \\ Spain; mel10anie@gmail.com (M.G.-H.); crisgcomplutense@gmail.com (C.G.-C.) \\ 2 Renal, Vascular and Diabetes Research Laboratory, IIS-Fundación Jiménez Díaz, Universidad Autónoma de \\ Madrid, 28040 Madrid, Spain; biomorgui@hotmail.com (J.L.M.-P.); lucasopazo78@gmail.com (L.O.-R.); \\ cvazqu01@ucm.es (C.V.-C.); smas@fjd.es (S.M.); asanz@fjd.es (A.B.S.); \\ carmen.herencia@quironsalud.es (C.H.); cgomez@fjd.es (C.G.-G.); jegido@fjd.es (J.E.) \\ 3 Spanish Biomedical Research Centre in Diabetes and Associated Metabolic Disorders (CIBERDEM), \\ 28040 Madrid, Spain \\ 4 Laboratorio de Nefrología, Facultad de Medicina, Universidad Austral de Chile, Valdivia 5090000, Chile; \\ mezzano.sergioa@gmail.com \\ 5 Department of Cell Biology, Physiology and Immunology, University of Cordoba, 140471 Cordoba, Spain \\ 6 Hospital Universitario Reina Sofía, 14004 Córdoba, Spain \\ * Correspondence: sandra.rayego@imibic.org (S.R.-M.); juan.moreno@uco.es (J.A.M.); \\ Tel.: +34-957-218-039 (S.R.-M.) \\ + These authors contributed equally to this work.
}

Received: 4 May 2020; Accepted: 26 May 2020; Published: 27 May 2020

\begin{abstract}
Diabetic nephropathy (DN) is associated with an increased morbidity and mortality, resulting in elevated cost for public health systems. DN is the main cause of chronic kidney disease (CKD) and its incidence increases the number of patients that develop the end-stage renal disease (ESRD). There are growing epidemiological and preclinical evidence about the close relationship between inflammatory response and the occurrence and progression of DN. Several anti-inflammatory strategies targeting specific inflammatory mediators (cell adhesion molecules, chemokines and cytokines) and intracellular signaling pathways have shown beneficial effects in experimental models of DN, decreasing proteinuria and renal lesions. A number of inflammatory molecules have been shown useful to identify diabetic patients at high risk of developing renal complications. In this review, we focus on the key role of inflammation in the genesis and progression of DN, with a special interest in effector molecules and activated intracellular pathways leading to renal damage, as well as a comprehensive update of new therapeutic strategies targeting inflammation to prevent and/or retard renal injury.
\end{abstract}

Keywords: inflammation; type 2 diabetes; diabetic nephropathy; chronic kidney disease; inflammation; drugs; and therapy

\section{Introduction}

Diabetic nephropathy (DN) is a common complication of type 1 and type 2 diabetes (T1DM and T2DM). DN is the leading cause of chronic kidney disease (CKD), increasing the morbidity and mortality of diabetic patients [1]. DN morphological abnormalities include early glomerular hypertrophy, glomerular basement membrane (GBM) thickening, podocyte depletion, mesangial 
matrix expansion, and tubular damage. In later phases, renal alterations include glomerulosclerosis and tubulointerstitial fibrosis, clinically characterized by the loss of renal function with or without albuminuria and progression to end-stage renal disease (ESRD) [2,3].

$\mathrm{DN}$ is a multifactorial disease characterized by the complex interaction of hemodynamic and metabolic factors, including high glucose blood levels, advanced glycation end-products (AGEs), and activation of the renin-angiotensin-aldosterone system (RAAS) [4]. Therefore, the current management of diabetic patients focuses on tight glycemic control and antihypertensive/lipid-lowering therapies; however, these interventions do not prevent the progression of CKD in a large proportion of patients $[5,6]$. For that reason, the search for novel therapeutic approaches against DN is an area of paramount importance.

Inflammation is a mechanism activated in response to harmful conditions to maintain tissue homeostasis and integrity. However, chronic activation of the inflammatory response triggers collateral injurious effects [7]. Although hyperglycemia, oxidative stress, and RAAS activation are the driving forces for renal damage associated with diabetes, numerous pieces of evidence point out the key role of inflammation in the development and progression of diabetic complications [8] (Figure 1). Thus, in the last years, the modulation of the inflammatory response has emerged as a potential strategy to decrease diabetic kidney disease $[9,10]$. These therapeutic approaches are based on inhibition of, adhesion molecules, chemokines, cytokines, immune cells, and intracellular signaling pathways involved in the inflammatory response. This manuscript aims to review the role of inflammation in DN-mediated kidney injury, with a special focus on immune cells, immunoinflammatory mediators, and cell signaling pathways, as well to fully address novel anti-inflammatory therapies to prevent and/or retard the progression of renal damage in this pathological context.

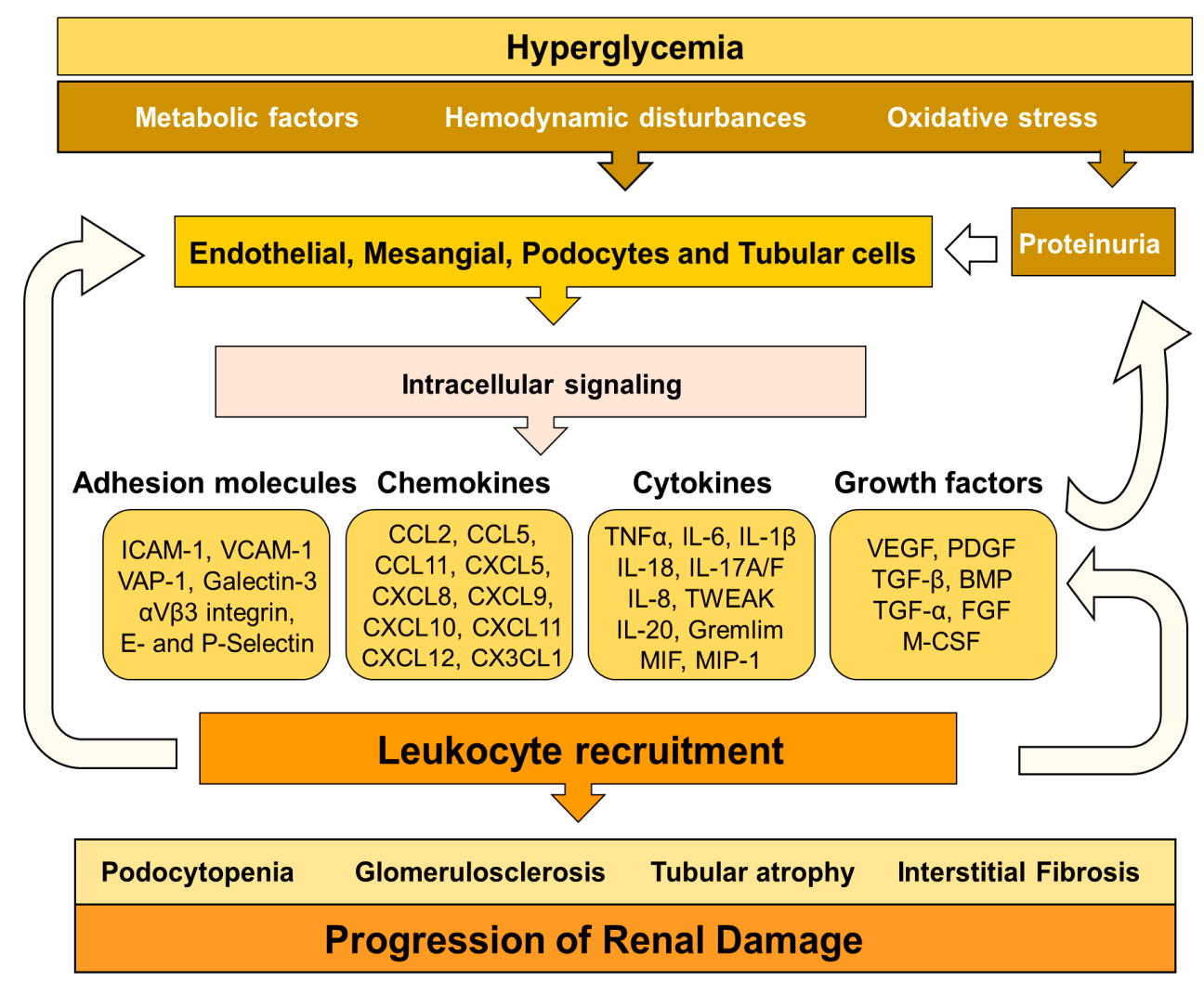

Figure 1. Mechanisms involved in inflammation, tissue injury and progression of renal damage in diabetic nephropathy (DN). 


\section{Mechanisms Triggering DN-Associated Inflammation}

In DN, hyperglycemia leads to the expression of inflammatory mediators (chemokines and cytokines) by injured glomerular and tubular cells, contributing to renal damage by different mechanisms: mesangial proliferation, podocyte/tubular damage and leukocyte infiltration [11,12]. These proinflammatory molecules also induce extracellular matrix deposition and differentiation/ proliferation of myofibroblast through different signaling pathways, such as NF- $\mathrm{B}$, JAK/STAT, TGF $\beta /$ Smad, among others [13-15].

In DN, both hyperglycemia and hemodynamic abnormalities elicit glomerular hyperfiltration, mechanical stress, glycocalyx dysfunction, and endothelium activation $[4,16]$. Consequently, endothelial cells upregulate the expression of adhesion molecules, glycosaminoglycans and chemokines, which are involved in the infiltration of leukocytes toward the renal interstitium [17]. Chemokines promote the activation of integrins by leukocytes, allowing the interaction of these cells with the endothelial adhesion molecules [18]. This interaction results in the adhesion of inflammatory cells to the endothelium and further transmigration to other tissues [19]. Once infiltrated in the inflammatory foci, leukocytes promote renal damage by two different mechanisms: (1) direct interaction and activation of glomerular and tubular cells, and (2) releasing chemokines, cytokines, and profibrotic factors that activate stromal renal cells. Then, these stromal renal cells secrete additional chemokines promoting further infiltration of leukocytes. All these events amplify the inflammatory response in a positive feedback loop that enhances renal damage $[9,12]$. Inflammatory molecules induce vascular remodeling, endothelial dysfunction, extracellular matrix deposition, mesangial proliferation, podocyte and tubular death, GBM thickness and glomerulosclerosis, which are hallmarks of diabetic kidney disease [2,20].

There is a close and retroactive relationship between oxidative stress and inflammation in DN [21-24]. Thus, experimental models of DN have demonstrated that the production of cytokines is partially promoted by hyperglycemia-mediated oxidative stress $[25,26]$. Studies in patients have demonstrated that glucose administration increased IL-6 or IL-18 plasma concentration, an effect that was reduced with the antioxidant glutathione [27]. In this line, a strong and independent relationship between oxidative stress markers and cell adhesion molecules (ICAM-1) and other inflammatory mediators (CCL2) was found in T1DM and T2DM patients [28,29]; however, vitamin E administration abolished this association [30-32]. The induction of proinflammatory factors by oxidative stress can occur through the activation of NF- $\mathrm{KB}$ and the activator protein-1 (AP-1), two key transcription factors mediating inflammatory response during $\mathrm{DN}$, as we will fully describe in the next sections of this review [25,33-35].

\section{Immune Cells and DN}

Cells of the innate and adaptive immune response are involved in DN. In the next section, we will fully address the role of these immune cells in this clinical condition.

\subsection{Macrophages}

Macrophages are early recruited during the genesis of renal injury in diabetes and are also associated with the progression of the disease [36,37]. Macrophage infiltration is mediated by several chemokines, including chemokine-CC motif ligand 2 (CCL2), CCL5, CXCL1, CXCL16, and CXCL10 chemokines receptors and adhesion molecules (ICAM-1 and E-selectin) [38-40].

Macrophages produce different molecules triggering renal injury in $\mathrm{DN}$, including reactive oxygen species, proinflammatory cytokines (IL-1 $\beta$ and TNF- $\alpha$ ), chemokines (CCL2), factors of the complement system, and metalloproteinases [38,39,41]. Macrophage activation and accumulation positively correlate with hyperglycemia, glomerular/tubular damage, endothelial activation, and decline of renal function [36]. Thus, macrophages induce proteinuria and glomerulosclerosis [42]. In a model of progressive DN, renal macrophage infiltration correlated with renal chemokine expression, such as CCL2, migration inhibitory factor, osteopontin, and monocyte colony-stimulating factor [36]. 
Moreover, preclinical studies in models of DN showed that glomerular and interstitial macrophages positively expressed activation markers such as sialoadhesin and inducible nitric oxide synthase [38]. Macrophages also release profibrotic mediators (PDGF and TGF- $\beta$ ) that elicit mesangial-mediated fibronectin production and fibroblast/mesangial proliferation [43].

Lipid abnormalities are frequent in diabetic patients. Hyperlipidemia induces macrophage-derived foam cells formation. Thus, macrophages exposed to serum samples from T2DM patients were transformed into foam cells [44]. An increased presence of foam cells was observed in the renal glomerulus of diabetic mice fed on a hypercholesterolemic diet [45]. Lipid lead macrophages release a high number of cytokines, thus contributing to the inflammatory process.

In the early and middle stages of DN, infiltrated macrophages are derived from recruited monocytes, which undergo polarization/differentiation towards a proinflammatory M1 phenotype rather than anti-inflammatory M2 phenotype. Indeed, macrophages isolated from diabetic kidneys showed the greatest expression of M1 markers (Ly6C, IL-6 and CCR2) than M2 markers (CD206 and CD163) [41]. In DN, polarization toward the M1 phenotype is related to the activation of several intracellular signaling pathways (NF- $\mathrm{KB}$, JAK/STAT, SREBP-1) in response to TNF- $\alpha$, glucose, and AGEs production [46,47]. The M1 macrophages produce TNF- $\alpha$, accelerating the inflammatory process in DN [48]. Moreover, M1 macrophages directly disturb podocyte integrity [41]. Specific deletion of cyclooxygenase- 2 in macrophages regulated the process of macrophage differentiation in DN [49]. The heterogeneity of macrophage phenotype and function ultimately determines the outcome of DN [50]. M2 macrophages secrete IL-10, with potent anti-inflammatory effects, such as the activation of HO-1 and the inhibition of TNF- $\alpha$ production [51]. Therefore, induction to the M2 phenotype has been one of the key goals of immune-based treatments for DN.

\subsection{Dendritic Cells}

Dendritic cells (DCs) are mononuclear phagocytes that reside in many organs, including the kidney. These antigen-presenting cells show different phenotypes and functions depending on the local microenvironment. In the kidney, DCs act as a bridge between innate and adaptive immunity [52] and participate in the tubulointerstitial immune cell cross-talk during the progression of DN $[53,54]$. Matured DCs produce cytokines and costimulatory molecules and activate T lymphocytes and renal macrophages, thus mediating inflammation and kidney damage. Experimental immunomodulatory strategies, such as mesenchymal stem cell transplantation and Fms-like tyrosine kinase 3 inhibitor, reduce the population and maturation of DCs and ameliorate inflammation and CKD [55,56]. However, there is still limited information about the distinct functions of DCs' subsets in the pathogenesis of DN.

\subsection{T Lymphocytes}

Several studies have demonstrated the increased presence of activated CD4+, CD8+ T cells in renal interstitium of patients with diabetes [57]. These T cells release IFN- $\gamma$ and TNF- $\alpha$, as noted in diabetic mice, thus contributing to the promotion of inflammation by activation of macrophages and endothelial cells [57]. Specifically, CD4+T cells also enhance fibrosis by activating fibroblasts [58]. The number of CD4+ T cells in diabetic kidneys correlated positively with proteinuria levels [57]. In the same line, induction of DN in mice without T and B lymphocytes (Rag1-/- mice) showed that lymphocytes activate glomerular macrophages, induce podocyte injury, and increase albuminuria [59]. Pharmacological inhibition of T-cell activation with CTLA4-Fc abatacept also reduced albuminuria in mice with DN [60].

CD4+ $\mathrm{T}$ cells can differentiate into different cell-subtypes, including T-helper subsets (Th1/Th2/Th17) and regulatory T cells (Tregs). Th1 and Th17 cells have been specifically associated with renal damage in DN. These inflammatory cells release chemokines in response to IL-1 $\beta$, IL-6, and TGF- $\beta$, which are frequently found in diabetic kidneys [48]. Targeting Th17 cells by mycophenolate mofetil attenuated albuminuria and tubulointerstitial fibrosis in mice with DN [61]. On the other hand, 
depletion of Tregs with anti-CD25 mAb exacerbates diabetic-associated renal injury in mice, whereas the adoptive transfer of Tregs had the opposite effect [62].

\subsection{B Lymphocytes}

B-cells are found in the glomeruli of diabetic patients and experimental models of DN, suggesting the involvement of these cells in this pathological setting [57,59]. The pathogenic role of B-cells in $\mathrm{DN}$ is based on their capacity to produce immunoglobulins (predominantly IgG and IgM isotypes) against neoantigens formed as a consequence of diabetes, such as AGE-LDL, malondialdehyde-LDL and oxidized-LDL $[63,64]$. These immunoglobulins activate specific $F_{C}$ receptors and the complement system $[65,66]$. In this line, increased IgG and C3 glomerular deposits were observed in experimental $\mathrm{DN}[36,59]$. Moreover, the presence of IgG in renal biopsies from diabetic patients was associated with worse outcomes [67]. Interestingly, diabetic mice lacking IgG Fc receptors had reduced renal damage, inflammation, and fibrosis [68]. Therefore, strategies aimed to reduce Fc receptor signaling in DN may be of interest.

\subsection{Mast Cells}

Mast cells are myeloid-derived immune cells with an important role in many autoimmune and inflammatory diseases. Mast cells infiltrate the diabetic kidney in all stages of the disease, and their number and degranulation levels increase in line with the progression of the disease in patients $[69,70]$. The anaphylatoxin C3a triggers mast cells activation and chemotaxis toward inflammatory foci, and probably may be responsible for their recruitment in DN [71]. Mast cells are also able to promote renal fibrosis via SCF/c-kit signaling pathway and induce tubular interstitial injury by increasing the production of proteases and inflammatory mediators, such as chymase, renin, TGF- $\beta 1$ and TNF- $\alpha[70,71]$. Inhibition or reduction of chymase-positive mast cells, ameliorated albuminuria in $\mathrm{db} / \mathrm{db}$ mice [72]. A clinical trial with the chymase inhibitor BAY1142524 in patients with DN is now completed, but no results have been yet posted (NCT03412006).

\subsection{Neutrophils}

There is limited information about the possible role of neutrophils in DN. Nevertheless, neutrophils from T1DM and T2DM patients have a higher capacity to adhere to endothelium as compared to those from normo-albuminuric patients [73]. Additionally, neutrophils release high amounts of ROS and TNF- $\alpha$, thus promoting endothelial damage and, therefore, accelerate DN-mediated renal damage $[74,75]$. Also, increased neutrophil to lymphocyte ratio has been associated with albuminuria in diabetic patients [76].

\section{Inflammatory Mediators in DN}

As previously described, cell adhesion molecules, chemokines and cytokines play a key role in renal damage associated with DN. In this section, we will fully address the key role of these molecules in DN-mediated renal damage as well as different therapeutic approaches targeting these proinflammatory molecules in this pathological condition (Figure 2).

\subsection{Cell Adhesion Molecules}

Cell adhesion molecules (CAMs) are implicated in leucocyte trafficking between blood and tissues. These molecules mediate leukocyte rolling on vascular endothelial cells and tightly adhere them to the endothelium to be further recruited to the inflammatory foci [77]. Therefore, CAMs mediate the interaction between leukocytes and endothelial cells, playing a key role in DN. There are many CAMs involved in the onset and development of diabetes-associated renal injury. 


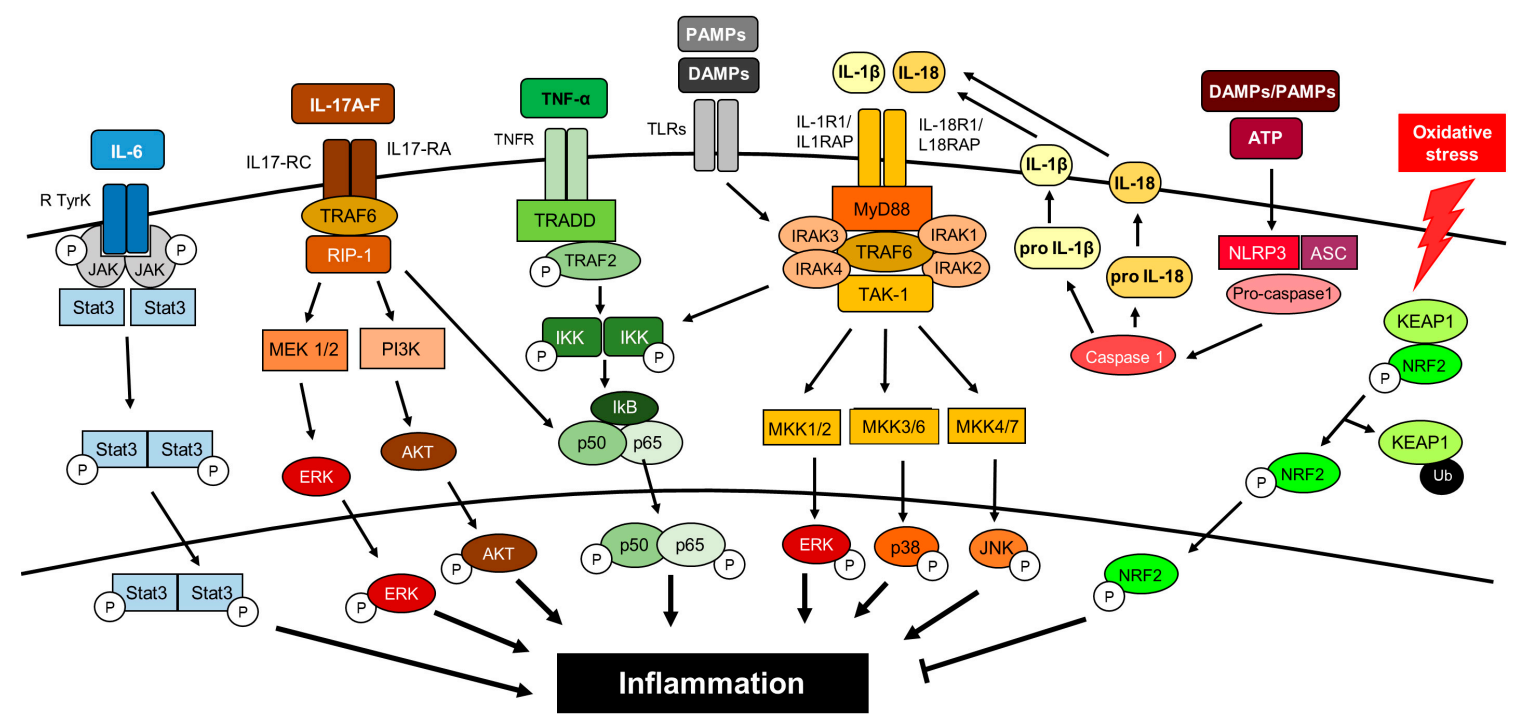

Figure 2. Cytokines and intracellular signaling pathways activating inflammation in DN. This is a simplified view since there are tremendous connections between the different pathways, indicating the complexity of the inflammatory response.

Intercellular adhesion molecule 1 (ICAM-1) is a cell adhesion molecule that interacts with macrophage-1 antigen (Mac-1) and lymphocyte function-associated antigen-1 (LFA-1). ICAM-1 expression is upregulated in endothelial cells of glomerular and interstitial capillaries by shear/oxidative stress and cytokines [78-80]. Plasma ICAM-1 levels are increased in T1DM and T2DM patients, being associated with urinary albumin excretion rate or microalbuminuria [81,82]. A recent meta-analysis showed that the rs5498 polymorphism is a risk factor for DN in Caucasian T1DM patients [83]. ICAM-1 gene deletion or the use of an anti-ICAM-1 antibody reduced macrophage infiltrate as well as decreased mesangial proliferation, glomerular Col IV expression and albuminuria in different experimental models of diabetes $[40,84]$.

Vascular cell adhesion molecule-1 (VCAM-1) was also found elevated in renal vascular endothelium and infiltrating leukocytes in diabetic kidneys. In T2DM patients, increased levels of VCAM-1 correlated with albuminuria [85] and were identified as a prominent mortality risk factor [86].

Vascular adhesion protein-1 (VAP-1) is an endothelial cell-surface oxidase that induces oxidative stress and cellular toxicity [87]. VAP-1 plasma levels are elevated in diabetic patients, being associated to eGFR decline and albuminuria [88,89], and may be related with cardiovascular and cancer mortality risk of these patients $[89,90]$. A recent phase II clinical trial in diabetic and CKD patients showed that the administration of the oral VAP-1 inhibitor ASP8232 in combination with RAS blockade, delayed progression of renal damage [91].

Galectin-3 is a $\beta$-galactoside binding lectin that has been related to DN because acts as a receptor for AGEs [92]. Circulating galectin-3 levels increased in line with loss of renal function and was associated with cardiovascular events and mortality in two clinical cohorts (4D and LURIC) [93]. The galectin-3 antagonist GCS-100 was used in diabetic patients with CKD, but results has not been yet posted (NCT02312050).

$\alpha \mathrm{V} \beta 3$ integrin is expressed by the glomerular endothelium and podocytes [94]. Increased expression of the $\alpha \mathrm{V} \beta 3$ integrin and its ligand (vitronectin) has been observed in kidneys from diabetic rats [95]. Blockade of the $\alpha \mathrm{V} \beta 3$ integrin using a monoclonal antibody decreased proteinuria and early histologic changes of diabetic nephropathy in pigs (Table 1) [96]. Moreover, the use of $\alpha \mathrm{v} \beta 3$ Integrin antagonist (MK-0429) in ZSF1 rats decreases proteinuria, renal fibrosis and collagen accumulation in diabetic damaged kidneys [97]. An ongoing clinical trial evaluates the effect of a $\alpha \mathrm{V} \beta 3$ integrin antibody in patients with DN, although no results have been published (NCT02251067). 
Selectins have been also implicated in DN, and E-selectin is the most studied one in this pathological context [98]. In diabetic mice, E-selectin expression is induced by IL-1 $\beta$ or TNF- $\alpha$ levels being observed in glomeruli, mainly located in endothelial cells [99], and this expression was correlated with the amount of CD14 positive interstitial cells [98]. In T1DM patients, increased E-selectin plasma levels have been reported, correlating with the decline of renal function and cardiovascular risk [100]. In the case of P-selectin, T2DM patients showed increased levels of P-selectin and associated to the severity of disease [101], an effect that was reduced with the combination of ARB olmesartan and the ACEi imidapril [102].

\subsection{Chemokines}

Chemokines are small soluble signaling proteins that can be involved in glomerular and tubulointerstitial inflammation. These molecules are released by resident renal cells recruiting and activating circulating leukocytes [103].

Several chemokines (CCL2, CCL5, CCL11, CXCL5, CXCL8, CXCL9, CXCL12, CX3CL1) and chemokine receptors (CCR2, CCR5, CXCR4, CX3CR1) were found to be elevated in kidneys of diabetic mice/rats and in renal biopsies from DN patients [104,105]. In diabetic kidneys, these chemokines and their cognate receptors are expressed by tubular cells and podocytes, as well as infiltrating leukocytes $[104,106]$. The renal expression of these proteins is progressively increased in line with macrophage infiltration, proteinuria and renal function decline [104]. Consequently chemokine urinary levels, such as CCL2, CXCL5, CXCL8 and CXCL9, are significantly elevated in later phases of diabetic kidney disease $[107,108]$. A study in patients with DN showed that urinary levels of CXCL9 and CXCL11 mRNA levels correlated with the eGFR decline [109]. CXCL12/SDF-1- $\alpha$ plasma levels were useful for predicting the progression of renal dysfunction in patients with coronary artery disease [110]. Therefore, urinary and/or systemic analysis of chemokine levels may be a useful clinical tool for patient risk stratification.

The expression of chemokines is directly upregulated by the diabetic harmful environment. Thus, CCL2 is activated by high glucose and AGE via NF-KB in mesangial cells [111]. The role of CX3CL1/CX3CR1 axis in DN has been recently reviewed [112]. CX3CL1 (fractalkine) was found in glomerular and peritubular capillaries, whereas CX3CR1 is expressed by T lymphocytes and activated monocytes/macrophages [113]. Experimental data indicated an important role of this axis in the progression of DN, as well as a direct relation with RAAS [113]. In DN, CX3CL1 pathogenic effects include mesangial cell proliferation via cellular reactive oxygen species (ROS) generation and activation of MAPK signaling pathway [114], extracellular matrix accumulation [115] and podocyte apoptosis [116]. Moreover, the inter-regulation of CX3CL1 and MMP2 mediates the crosstalk between monocytes and mesangial cells in the context of DN [117].

In experimental models of $\mathrm{DN}$, targeting chemokines and its receptors reduced renal inflammation and the subsequent pathological consequences, including oxidative stress, fibrosis, and glomerular damage [36,118]. There are many strategies to modulate the action of chemokines and its receptors, such as the use of specific chemokines receptor antagonists or chemokine inhibitors. For example, the blockade of CXCL12 by the specific inhibitor NOX-A12 diminished podocytopenia and glomerulosclerosis independently of glycemic control or glomerular macrophage infiltration [119]. The pharmacological inhibition of CXCR4 in diabetic rats with the small molecule inhibitor AMD3100 increased albuminuria, reduced VEGF excretion, and accelerated tubular epithelial cell death, indicating that CXCR4 may be a promoter of renal tubular cells survival [106]. In diabetic mice, the injection of a recombinant murine CXCL10 reduced albuminuria, mesangial and peritubular cell expansion, and glomerular hypertrophy [120]. In experimental diabetes, several CCR2 antagonists (such as propagermanium, CCX140-B, RO5234444, RS102895 or RS504393) selectively blocked CCL2-dependent monocyte activation and provided beneficial metabolic effects against DN-mediated podocyte injury and albuminuria [121-124]. A new area of interest is the inhibition of multiple chemokines at the same time. For example, dual inhibition of CCL2 and CXCL12 with specific RNA enantiomers (CCL2-specific 
mNOX-E36 and the CXCL12-specific NOX-A12) had additive effects against diabetic-associated renal injury [125].

These positive experimental data have been confirmed in human clinical trials. Thus, the CCR2 inhibitor CCX140-B administered for up 52 weeks reduced urinary albumin/creatinine ratio (UACR) in patients with DN [126]. In the same line, inhibition of CCL2/CCR2 signaling with emapticap pegol (NOX-E36) for up 12 weeks showed beneficial effects on urine albumin levels and reduced high blood glucose levels in T2DM patients with residual albuminuria on RAAS blockade [127]. However, no protective effects were observed during 12 weeks of treatment with F-04634817, a dual chemokine CCR2/5 receptor antagonist, in T2DM patients that were on ARBs and/or ACEi therapy [128]. In that study, patients had high levels of albuminuria and low eGFR at baseline, suggesting that the beneficial effects of chemokine targeting may be more effective at earlier stages of DN.

Table 1. Selected preclinical studies targeting inflammatory mediators in DN.

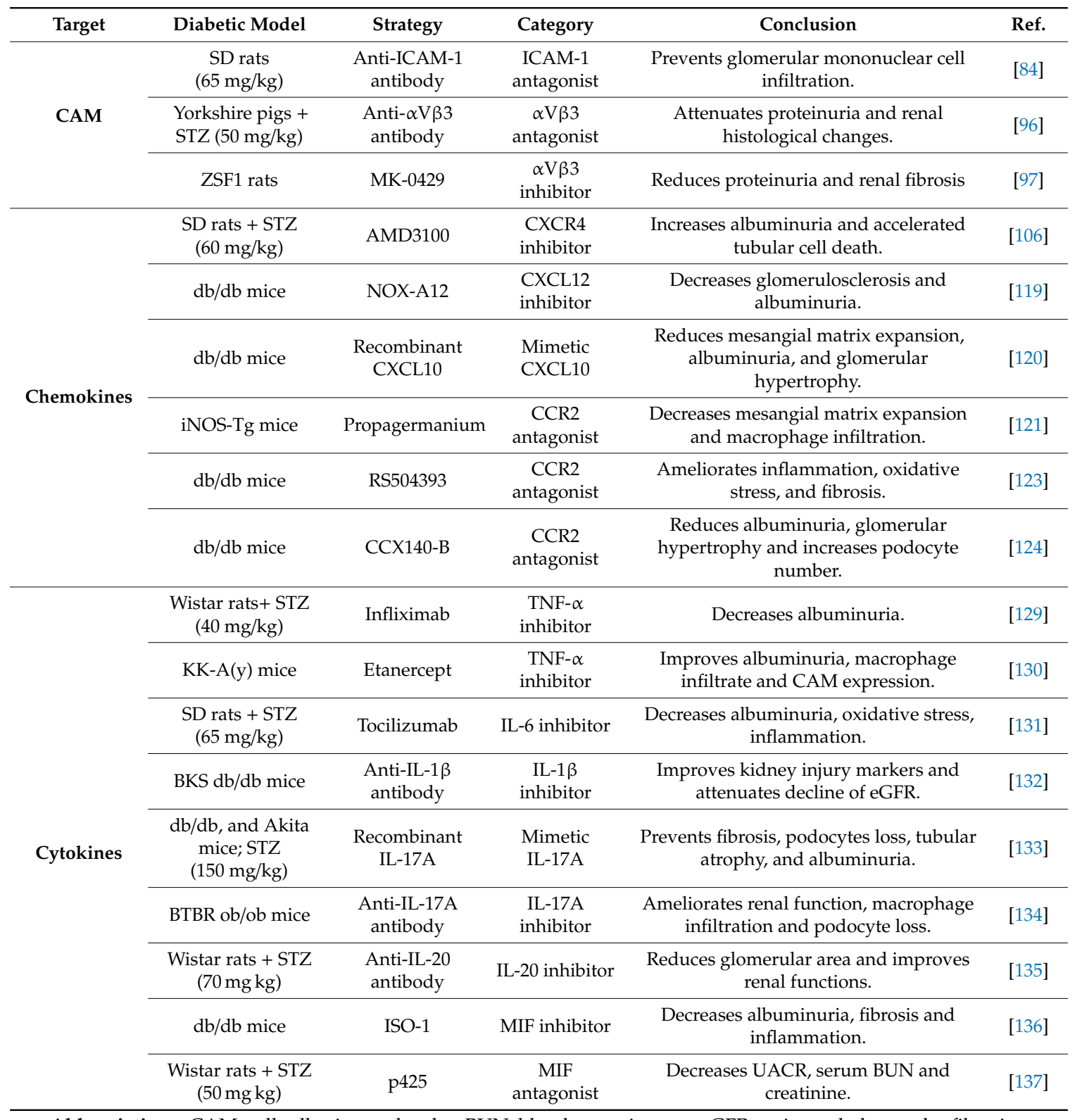

Abbreviations: CAM: cell-adhesion molecules; BUN: blood urea nitrogen; eGFR: estimated glomerular filtration rate; STZ: streptozotocin; SD: Sprague Dawley; ZSF1: Zucker fatty/spontaneously hypertensive heart failure F1 hybrid. 


\subsection{Cytokines}

\subsubsection{TNF- $\alpha$}

TNF- $\alpha$ influences the recruitment and activation of leukocytes, exacerbating DN-associated inflammatory response [11,138]. In diabetic kidneys, TNF- $\alpha$ and its receptors TNFR1 and TNFR2, are involved in the synthesis of cytokines, chemokines, growth factors, extracellular matrix proteins and mediate a wide variety of cytotoxic effects on podocytes, mesangial, endothelial and epithelial cells [138-140]. Moreover, the serum and urinary levels of TNF- $\alpha$ are increased in patients with DN compared to healthy controls and there is a close relationship with albuminuria in diabetic patients, suggesting TNF- $\alpha$ as a potential prognostic biomarker in DN [140-142]. TNF- $\alpha$ receptors can be shed from the extracellular membrane as two soluble proteins, named sTNFR1 and sTNFR2. These molecules were able to predict the loss of eGFR and ESRD in T1DM and T2DM patients $[140,143,144]$. In a recent study, 194 circulating inflammatory proteins were analyzed in T1DM and T2DM subjects from three independent cohorts, identifying an extremely robust kidney risk inflammatory signature (KRIS), consisting of 17 proteins of the TNFR superfamily members that were associated with a 10-year risk of ESRD [10]. Therefore, these proteins may be new prognostic biomarkers for progressive DN. Some treatments, such as pentoxifylline and ACEi, reduced the TNF- $\alpha$ renal expression in mice and patients with diabetes $[139,145]$. In those studies, the reduction of TNF- $\alpha$ levels was directly associated with the decline of albuminuria, highlighting a pathogenic role of TNF- $\alpha$ in DN. In the PREDIAN trial, patients with T2DM and CKD (stages 3-4) were treated with pentoxifylline in addition to RAAS inhibitors for 2 years, resulting in a smaller decrease in eGFR and greater reduction of residual albuminuria, coinciding with a marked reduction in urinary TNF- $\alpha$ [146]. Recently, new clinical trials have proposed pentoxifylline as a possible therapeutic agent in this pathological context (NCT03664414; NCT03625648). There are strategies specifically targeting TNF- $\alpha$ in this pathological context. A soluble TNF- $\alpha$ antagonist (TNFR:Fc) reduced urinary TNF- $\alpha$ excretion as well as renal damage associated with DN [147]. Similar results were observed with the monoclonal antibody infliximab, a TNF- $\alpha$ inhibitor that reduced albuminuria in experimental diabetes [129]. Etanercept, a soluble TNFR2 fusion protein targeting TNF- $\alpha$-TNFR2 pathway, reduced the levels of cell adhesion molecules, macrophage renal infiltrate, and albuminuria in diabetic mice [130]. However, to our knowledge, no clinical studies are targeting TNF- $\alpha$ in the context of renal complications of diabetes.

\subsubsection{IL-6}

Il-6 is a cytokine that plays a key role in inflammatory pathologies. A recent meta-analysis in patients with DN revealed the essential role of different polymorphisms of IL-6 such as rs1800795, rs1800796, and rs1800797 in the development and progression of DN [148]. The IL-6-174 G allele increased the risk to develop renal complications in T2DM patients [149]. These pieces of evidence suggest that IL-6 may be related to DN. Increased IL-6 urinary levels were found in patients with DN, mainly in those with worse renal outcomes [150]. Some therapies have been developed to inhibit IL-6 signaling pathway [151]. Tocilizumab, a humanized antibody that blocks the IL-6 receptor (IL-6R), attenuated the histopathological changes induced by streptozotocin (STZ) in rats, by decreasing inflammation and oxidative stress [131]. Clinical trials provided metabolic beneficial effects of anti-TNF- $\alpha$ agents (infliximab, etanercept, adalimumab, golimumab, and certolizumab pegol) or IL-6 inhibitor (tocilizumab) on $\mathrm{HbA1c}$, insulin resistance and insulin sensitivity in T2DM patients with psoriasis [152] or rheumatoid arthritis [153].

\subsubsection{IL-1 $\beta$}

Interleukin-1 $\beta$ (IL-1 $\beta$ ) is one of the most potent molecules of the innate immune system implicated in macro- and micro-vascular complications of diabetes [154-156]. This cytokine is highly produced by macrophages and triggers the production of other secondary proinflammatory mediators by renal cells [157]. Indeed, IL-1 $\beta$ induced tubulointerstitial fibrosis throughout the activation of the MYC 
transcription factor, with further dysregulation of glycolysis and matrix production [158]. Several studies described that IL-1 $\beta$ causes endothelial cell damage in resistance arteries and identified its deleterious effect due to the NADPH oxidase activation $[159,160]$.

Therapeutics approaches have targeted IL- $1 \beta$ in diabetes. For example, in uninephrectomized $\mathrm{db} / \mathrm{db}$ mice, an anti-IL-1 $\beta$ antibody reduced fibrosis, podocyte injury, and progressive decline of eGFR [132]. In the clinical field, the studies analyzed the role of IL-1 $\beta$ blockade in renal disease are not conclusive. In the CANTOS study (Canakinumab Anti-inflammatory Thrombosis Outcome Study), the blockade of IL-1 $\beta$ with canakinumab diminished inflammatory markers (hsCRP and IL-6) and the cardiovascular risk in atherosclerosis patients, but did not reduce the incidence of diabetes [161,162]. The treatment with canakinumab did not show substantive benefits on eGFR, serum creatinine, and UACR [162]. On the other hand, Cavelti-Weder et al. showed that the treatment with gevokizumab, a novel human-engineered monoclonal anti-IL-1 $\beta$ antibody, improved glycemia by restoring insulin production/action and reduced inflammation in patients with T2DM [163]. Another clinical trial in T2DM patients showed that the IL-1 $\beta$-receptor antagonist anakinra improved glycemia and $\beta$-cell function and reduced systemic inflammatory markers [164]. The new IL-1 $\beta$ inhibitor rilonacept reduced systemic inflammation in patients with CKD [165], but not in T1DM patients [166]. All these results showed the key role of IL-1 $\beta$ in the development and progression of diabetic disease, but new studies are needed to confirm the clinical significance of this finding.

\subsubsection{IL-18}

Interleukin-18 (IL-18) is a member of the IL-1 cytokine family activated by inflammasome [167] that induces the expression of another cytokines and proinflammatory genes associated with apoptosis, oxidative stress, angiogenesis and cellular adhesion, such as NOX-4, p53, Il-8, TNF- $\alpha$, VEGF and ICAM-1 [167-169]. IL-18 expression is upregulated by activation of the MAPK signaling pathway in tubular epithelial cells of diabetic subjects [170]. IL-18 increases the maturation of T lymphocytes and natural killer cells, as well as the production of other proinflammatory cytokines in obesity-induced systemic inflammation [171]. Among the different cytokines involved in DN, IL-18 seems to be the most specifically associated with these metabolic and cardiovascular risk factors [172,173]. In renal biopsies of diabetic patients, IL-18 levels were found mainly increased in proximal tubular epithelial cells [170]. IL-18 has been described as a good serum and urinary predictive marker for DN [170,173]. Moreover, urinary levels of IL-18 were positively correlated with albuminuria and kidney injury progression in T2DM individuals, suggesting a close relationship with disease progression [142,174,175]. Two studies have analyzed the efficacy of GSK1070806, a humanized IgG1/kappa antibody against IL-18 in obese and T2DM patients, but there are no studies performed in DN $[176,177]$.

\subsubsection{IL17A}

IL-17A is a cytokine produced by multiple cell types, including CD4+ $\alpha \beta \mathrm{T}$ cells, $\gamma \delta \mathrm{T}$ cells, natural killer cells, neutrophils, macrophages, dendritic cells, lymphoid tissue inducer cells, mast cells and plasma cells [178]. IL-17 proteins, including IL-17A and IL-17F, interact with its receptors (IL-17RA-IL-17RE) and trigger downstream signaling pathways associated with inflammatory response, such as NF-KB, and oxidative stress [178,179]. IL-17A has been involved in the pathogenesis of immune and inflammatory diseases, including cardiovascular and renal diseases $[178,180]$. Previous studies described that Treg/Th17 ratio in T1DM patients was dysregulated, and those patients with reduced $\beta$-cell function showed increased levels of IL-17A+ in comparison with the number of Tregs, CD4+ $\mathrm{T}$ cells, and CD8+ T cells $[181,182]$. Recent studies in diabetic patients demonstrated that serum levels of IL-17A and IL-2 (Th17-associated cytokines) were increased when compared to healthy individuals [183,184].

In experimental models of DN, there are opposite results about the role of IL-17 in the renal diabetic pathology [185]. The gene blockade of IL-17A in mice increased the severity of renal damage induced by STZ injection. In the same study, the low dose administration of IL-17A and IL-17F 
in Akita diabetic mice reduced renal damage and recovered renal function via inhibition of the STAT3 signaling pathway [133]. Nevertheless, other reports showed opposite results, demonstrating that the systemic administration of IL-17A increased levels of blood pressure and inflammatory cell infiltration in the renal tissue in mice [186]. Moreover, other studies found increased IL-17A levels in serum from hypertensive patients [187]. A recent study by Lavoz et al. in BTBR ob/ob mice showed that the blockade of IL-17A with a neutralizing antibody improved albuminuria and renal pathological effects induced by diabetes [134]. Currently, some clinical trials are studying the role of IL-17A blockade with neutralizing antibodies such as secukinumab and ixekizumab in chronic human inflammatory diseases, including ankylosing spondylitis (NCT01358175; NCT01649375) [188], chronic plaque psoriasis (NCT01107457) [189] and psoriatic arthritis (NCT02404350) [190]. In the case of IL-17F, this isoform has been identified as a circulating inflammatory protein associated with increased risk of the progression of renal injury in T1DM and T2DM, among others [10]. However, there are controversial results about the serum levels of IL-17 and the severity of renal damage. Interestingly, circulating IL-17A levels were diminished in T2DM patients with or without DN when compared with normal glucose tolerance subjects [191]. Besides, plasma and urine IL-17A levels were reduced in patients with advanced DN and macroalbuminuria [133]. This data is opposite to the results obtained in a report in patients infected with cirrhotic hepatitis $C$ virus. In this study, the circulating levels of IL-17A were increased in T2DM cohort [192]. Due to these controversial results, more studies about the role of IL17 signaling pathways in DN are needed.

\subsection{Other Cytokines/Proinflammatory Proteins in DN}

Among several proinflammatory proteins involved in the development and progression of DN is also the cytokine IL-8, which mainly attracts neutrophils and induces oxidative stress, favoring vascular permeability and endothelial damage in the diabetic kidney $[193,194]$. Genetic polymorphism of IL-8 (IL8-rs4073) showed a strong association in Asian people with DN [195]. Other studies showed elevated circulating IL-8 levels in T2DM patients [193]. A bioinformatic analysis in endothelial precursor cells isolated from patients with T2DM showed that IL-8 and CXCL1 genes were the most expressed molecules in diabetic samples [196].

Tumor necrosis factor-like weak inducer of apoptosis (TWEAK) is a member of the TNF superfamily. Recently, the expression of TWEAK and its canonical receptor Fn14 was found dysregulated in the ZSF1 DN rat model, correlating with proteinuria and inflammation (CCL2 levels) [197]. Serum sTWEAK levels gradually decreased in T2DM patients in line with DN progression [193]. In another study, a negative correlation has been described between TWEAK and YKL-40, a potential biomarker for early diagnosis of incipient DN [198]. In a clinical trial in T2DM hypertensive patients with proteinuria, the combined therapy with RAAS blockers and calcium channel blockers normalized proteinuria, sTWEAK and PTX3 levels [199].

IL-20 is a pleiotropic cytokine associated with the inflammatory response that is expressed in the epithelium, endothelial cells, and monocytes/macrophages and is related to renal damage $[200,201]$. Hyperglycemia, ROS and TGF- $\beta 1$ upregulated IL- $20 \mathrm{mRNA} /$ protein expression in podocytes of STZ-diabetic mice [135]. Deficiency in IL-20R1 and blockade of IL-20 with anti-IL-20 mAb 7E reduced UACR, mesangial cell expansion, and podocyte apoptosis in experimental diabetes. In the same study, experiments in cultured podocytes stimulated with IL-20 showed an increase in MMP-9, CCL2, TGF- $\beta 1$, and VEGF gene expression levels [135,200]. Finally, serum IL-20 levels in DM patients were significantly elevated compared to healthy controls [135].

Gremlin, a bone morphogenetic protein 7 (BMP-7) antagonist, was identified as one of the developmental genes differentially expressed in diabetic kidneys [202]. In DN experimental models, the gremlin blockade ameliorates renal damage [203], and tubular overexpression of Gremlin in transgenic mice aggravates glomerular and tubulointerstitial injury [204] suggesting that Gremlin could be a novel therapeutic target for DN. In human biopsies of DN, Gremlin expression correlated with the grade of tubulointerstitial fibrosis and inflammation, colocalizing with TGF $\beta 1$ overexpression 
and Smad pathway activation [205]. Gremlin binds to vascular endothelial growth factor receptor 2 (VEGFR2) in endothelial and tubular epithelial cells, regulating the tubular epithelial to mesenchymal transition (EMT), and therefore, could contribute to renal fibrosis [206]. Gremlin activates the VEGFR2 signaling pathway in the kidney, eliciting a downstream mechanism linked to the renal inflammatory response [207]. Recently, VEGFR2 blockade, using a VEGFR2 kinase inhibitor, improved renal function, glomerular damage (mesangial matrix expansion, GBM thickening, and podocyte injury) and tubulointerstitial inflammation in T2DM model BTBR ob/ob [208].

Progression of DN has been also related to migration inhibitory factor (MIF), a cytokine that takes part in immune/inflammatory pathological response in DN, mainly associated with macrophage accumulation/activation [209]. In the KORA S4 study, serum MIF levels were increased in db/db mice [36] and T2DM patients [210]. Besides, increased levels of CD74 (MIF receptor) have been also reported in clinical and preclinical reports [211]. Wang et al. described that the pharmacological blockade of MIF with ISO-1 in db/db mice induced a significant decrease in albuminuria, blood glucose levels, extracellular matrix deposition, EMT, and macrophage activation in damaged kidneys [136]. Moreover, the use of the MIF antagonist (p425) in STZ-induced diabetic rats, decreased the loss of renal function (protein excretion, UACR, and serum BUN and creatinine levels) [137].

Macrophage inflammatory protein-1 (MIP-1), a chemokine produced by macrophages after the recognition of pathogens, is predominantly elevated in the early stages of DN [212]. Multiplex analyses of urinary inflammatory proteins revealed that levels of MIP- $1 \alpha$ and MIP- $1 \beta$, along with other chemokines and cytokines, were significantly increased in microalbuminuric DN patients compared to healthy controls [213], although only IP-10 and CCL2 correlated with albumin excretion rate and eGFR [213].

Other clinical trials are now targeting cytokines (IL-33) and growth factors (TGF $\alpha / \beta)$ by using humanized monoclonal antibodies in patients with DN (NCT04170543, NCT01113801, NCT01774981).

\section{Inflammatory Intracellular Signaling Pathways}

Dysregulation of several signaling pathways leads to persistent inflammation and has been found to be involved in the onset and progression of DN (Figure 3).

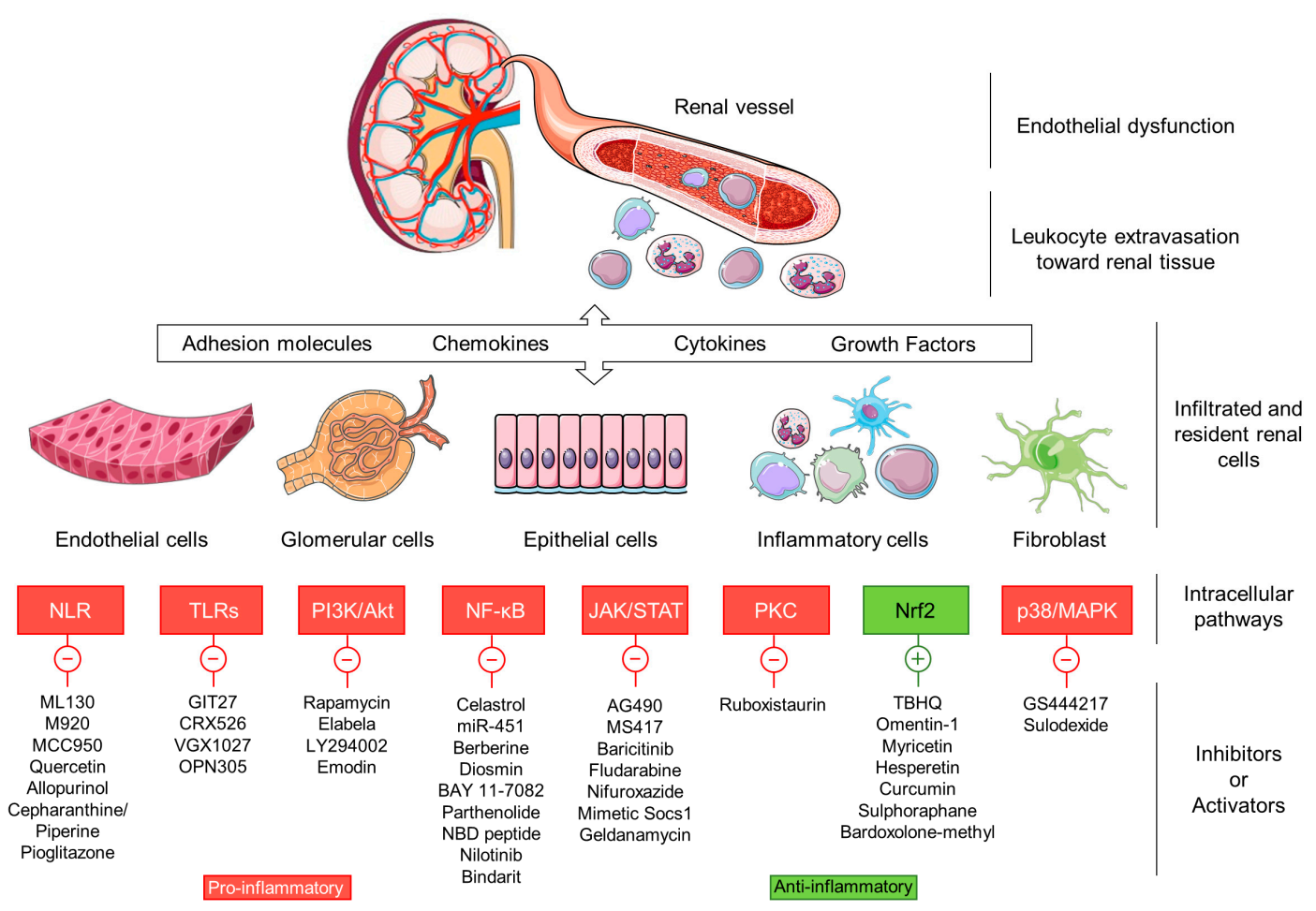

Figure 3. Therapeutic compounds targeting proinflammatory intracellular signaling pathways in DN. 


\subsection{Nod-Like Receptors}

Nucleotide-binding oligomerization domain (NOD)-like receptors (NLR) are pattern-recognition cytoplasmic receptors that link innate immunity, inflammation and metabolism in diabetes [214]. NLRs are classified into four functional categories: autophagy, signal transduction, transcription activation and inflammasome formation [214,215]. Nucleotide-binding oligomerization domain-containing protein 1 (NOD1) and NOD2 are critical members of the signal transduction pathway that contribute to inflammation in DN [216]. High glucose concentrations increased NOD1, NF-kB and IL-1 $\beta$ expression in cultured mesangial cells, an effect reverted with the NOD1 inhibitor ML130 [217]. On the other hand, NOD2 is highly expressed in renal biopsies from diabetic patients, correlating with the severity of the disease. In the same study, hyperglycemia activated NOD2 expression in glomerular vascular endothelial cells, which promoted endothelial-to-mesenchymal transition in a MEK/ERK-mediated way [218]. Oxidative stress also activates NOD2 expression post-transcriptionally throughout the RNA-binding protein human antigen R [219]. AGEs, TNF- $\alpha$, and TGF- $\beta$ are also involved in NOD2 overexpression by podocytes [216]. Reduced nephrin expression was noted in kidney form NOD2-knockout mice with a high-fat diet/STZ-induced diabetes [216].

The NLRP family, pyrin domain-containing protein (NLRP) is composed of NLRP1, NLRP3, NLRP6 and NLRC4, which are key components of different inflammasomes [215]. Inflammasome has been implicated in metabolic disorders such as diabetes, obesity and atherosclerosis. In particular, the activation of the NLRP3 inflammasome participates in the production and persistence of inflammatory response in DN [220]. Previous in vivo and in vitro studies showed that hyperglycemia increases the expression of NLRP3 and activates caspase-1, inducing the release of IL-1 $\beta$ and IL-18 [221,222]. In renal tubular epithelial cells stimulated with high glucose or transforming growth factor- $\beta 1$ (TGF- $\beta 1$ ), knockdown of NLRP3 reduced ROS production and prevented EMT by inhibiting the phosphorylation of Smad3, p38/MAPK and ERK-1/2 [223]. Moreover, a study in 135 diabetic subjects with or without DN, revealed that CASP1 mRNA expression was significantly associated with decreased eGFR and severity of DN [224].

The gene blockade of NLRP3 in diabetic mice improved renal function, glomerular hypertrophy, glomerulosclerosis, mesangial expansion and inflammation as well as the activation of Smad3 signaling pathway [225]. Wang et al. showed that the overexpression of renal inflammasome components NLRP3, apoptosis-associated speck-like protein and caspase-1 in a STZ-rat model caused an increase in hyperuricemia, hyperlipidemia as well as elevated levels of IL-1 $\beta$ and IL-18. Also, treatment with the flavonoid quercetin and the uric acid-lowering drug allopurinol, reduced the expression of these inflammatory markers and ameliorated kidney damage [226]. On the other hand, the use of the anti-inflammatory compounds such as cepharanthine and piperine in a rat model of DN ameliorated hyperglycemia and renal dysfunction, and also decreased NLRP3 and NF- $\mathrm{KB}$ expression in diabetic kidneys [227]. In the diabetic apolipoprotein E knockout (apoE-/-) mice, administration of PPAR- $\gamma$ agonist pioglitazone downregulated the expression of AGEs, RAGE, and NF- $\mathrm{kB}$, and also diminished NLRP3, caspase-1, IL-18, and IL-1 $\beta$ levels [228]. MCC950, a selective inhibitor of NLRP3 andM920, a broad specificity caspase inhibitor, improved renal function, GBM thickening, podocyte injury, renal fibrosis, and NLRP3-dependent markers in db/db mice [229,230].

\subsection{Toll-Like Receptors}

Recent studies highlight the essential role of toll-like receptors (TLRs), especially TLR2 and TLR4, in DN. TLRs induce renal injury and fibrosis via the NF- $\kappa B$ signaling pathway [231]. Therefore, reducing the inflammatory response associated with TLRs may provide a new therapeutic approach in diabetic kidney disease. In a mouse model of advanced DN, administration of the TLR4 antagonist CRX526 significantly decreased albuminuria, blood urea nitrogen, glomerular hypertrophy, glomerulosclerosis and tubulointerstitial injury, an effect related to the impairment in CCL2/CCL5 levels, TGF $\beta$ and NF- $\mathrm{KB}$ activity [232]. Mixed approaches are also being tested, such as the administration of GIT27 (VGX-1027), a TLR4 and TLR2/6 signaling pathway modulator, that effectively improved insulin resistance and 
protected from renal injury in a $\mathrm{db} / \mathrm{db}$ mice by reducing proinflammatory cytokine synthesis and oxidative stress [233]. Besides TLRs antagonists, several anti-TLR antibodies are being developed and tested. OPN305, a humanized monoclonal antibody against TLR2, is currently in phase II of a clinical trial that analyzes the prevention of delayed graft function (NCT01794663). Currently, no clinical studies are targeting TLRs signaling in diabetic kidney disease.

\subsection{PISK/AKT/mTOR}

Phosphatidylinositol 3-kinase/protein kinase B/mammalian target of rapamycin (PI3K/Akt/mTOR) signaling pathway regulates metabolism, proliferation, cell cycle, and protein expression, and its imbalance is involved in the development of obesity and diabetes [234]. However, the role of this pathway in $\mathrm{DN}$ is still controversial, suggesting the importance of discriminating the contribution of single PI3K isoforms in the diabetic kidney [235].

Recent studies indicate that hyperglycemia activates PI3K/Akt/mTOR, leading to glomerular hypertrophy, podocyte damage, and progressive deterioration of kidney function [236,237]. Specific $\mathrm{PI} 3 \mathrm{~K} / \mathrm{Akt} / \mathrm{mTOR}$ activation in podocytes generates proteinuria and mesangial cell expansion [238]. Inhibition of this pathway with rapamycin decreases macrophage infiltration and CCL2 release [239]. Furthermore, in a mouse model of diabetes, the treatment with mangiferin reduced IL-6, TNF- $\alpha$, and Il-1 $\beta$ expression by inhibiting PTEN/PI3K/Akt pathway [240].

On the other hand, treatment with the peptide hormone Elabela activated PI3K/Akt/mTOR and reduced renal inflammation in diabetic mice by decreasing CCL2, ICAM-1, and TNF- $\alpha$ production [241]. In the same line, an engineered partial agonist of fibroblast growth factor-1 (FGF1 ${ }^{\triangle H B S}$ ) showed antioxidative effects and anti-inflammatory activities in $\mathrm{db} / \mathrm{db}$ mice and also reduced oxidative stress and proinflammatory gene expression in podocytes challenged with high glucose by activating PI3K/Akt signaling [242]. Resveratrol has also shown to prevent experimental DN by regulating PI3K/Akt components in kidney tissue [243]. Likewise, in HK-2 tubular cells under high glucose conditions, treatment with the flavonoid apigenin reduced the release of TNF- $\alpha$, IL- $1 \beta$, and IL- 6 via PI3K/Akt. The PI3K/Akt inhibitor LY294002 also reversed TNF- $\alpha$ reduction in these cells [244]. Moreover, in an experimental model of DN in rats, the treatment with emodin reduced IL- 6 and TNF- $\alpha$ expression by the activation of PI3K/Akt/GSK-3 $\beta$ pathway [245]. Although several PI3K inhibitors have been approved for clinical use against malignant hematopoietic diseases, none of these drugs have been tested so far in the treatment of human diabetes mellitus and its complications [235].

\subsection{Nuclear Factor- $\kappa B$}

NF- $\mathrm{KB}$ (nuclear factor-kappa B) is a ubiquitous transcription factor that modulates the expression of chemokines, cytokines, and adhesion molecules. Inhibition of NF- $\kappa B$ has been addressed through the use of molecules that target receptors, upstream activating kinases, protein degradation, adapter molecules, nuclear translocation, and DNA binding [246]. Numerous studies focus on the potential beneficial effects of NF- $k B$ inhibition on the pathophysiological processes associated with DN [247]. This is the case of celastrol, a pentacyclic triterpenoid isolated from Tripterygium wilfordii and Celastrus regelii root extracts, which has shown beneficial effects on insulin resistance, body weight, renal injury, proinflammatory cytokine levels and mesangial matrix cell expansion through NF-kB inhibition [248]. In another study, intraperitoneal administration of miR-451 reduced NF- $\mathrm{KB}$ activity and improved microalbuminuria, glomerular damage and blood glucose levels in a DN animal model [249]. The inhibition of NF-KB by berberine (alkaloid of the isoquinoline family isolated from Cortex phellodendri and Coptidis rhizome) reduced the accumulation of extracellular matrix in the kidney, decreasing the levels of TGF- $\beta 1$, ICAM-1, fibronectin and improving renal function [250]. Administration of diosmin, a flavonoid derivative, inhibited NF- $\mathrm{kB}$ signaling, and reduced renal levels of proinflammatory cytokines and oxidative stress in an alloxan-induced DN model [251]. On the other hand, selective blockade of IKB kinase (IKK) complex using the IKK $\alpha / \beta$ inhibitors (BAY 11-7082, parthenolide), IKK $\gamma$ NBD inhibitory peptide, and BCR-ABL tyrosine kinase inhibitor (nilotinib) also had renoprotective effects in 
experimental models by reducing NF- $\mathrm{KB}$ activation, cytokine levels and oxidative stress and improving antioxidant defenses [252-255]. Recently, we have observed that inhibition of heat shock protein 90, a molecular chaperone required for stabilization/activation of IKK complex, led to a decreased expression of proinflammatory NF- $\mathrm{kB}$ target genes and ameliorated albuminuria, renal inflammation and fibrosis in diabetic mice [256]. In the clinical setting, bindarit an anti-inflammatory small compound that inhibits p65 and p65/p50-mediated CCL2 transcription, is being evaluated as a potential therapy for $\mathrm{DN}$ in association with irbesartan, but the results of this phase II clinical study have not yet been published (NCT01109212). However, it is necessary to consider the complexity of the signaling pathway associated with NF- $\mathrm{KB}$ and the diversity of the processes modulated by this transcription factor, which could complicate its use as a therapeutic target in DN.

\subsection{JAK/STAT}

The Janus kinases (JAK) family is comprised of four JAK tyrosine kinase receptors (JAK1, JAK2, JAK3, and TYK2), while seven members of the signal transducers and activators of transcription (STAT) family have been identified (STAT1-4, 5a, 5b and 6) [257]. These transcription factors can homoor hetero-dimerize and activate the transcription of proinflammatory target genes [258]. Although JAK/STAT signaling actions are mainly regulated by phosphorylation of tyrosine and serine residues, "nonphosphorylated STAT" functions have also been described by several authors, as well as the epigenetic regulation of JAK without STATs mediation $[259,260]$. Unlike other signaling pathways, the regulation of the JAK/STAT is recognized for its simplicity, nevertheless, the wide capacity to interrelate with other cell signaling pathways such as PI3K/Akt/mTOR and MAPK/ERK axis, complicate their intracellular activity [261,262].

Among the various actions attributed to the JAK/STAT pathway, its involvement in inflammatory-based diseases appears to be inherent. Due mainly to being a major effector pathway of cytokines and others inflammatory mediators, modulation of JAK/STAT signaling has resulted in significant clinical advances in the oncology field and also in immune disorders such as rheumatoid arthritis, systemic lupus erythematosus and psoriasis [257,263].

JAK/STAT pathway is involved in the pathogenesis of DN [264,265]. Clinical and experimental studies demonstrate JAK1-3, STAT1, and STAT3 overactivation in the progression of DN $[14,266]$. Deleterious effects of JAK/STAT overactivation are mainly produced by the gene expression of cytokines, chemokines, adhesion molecules, transcription factors, growth factors, extracellular matrix proteins, pro-oxidant enzymes and scavenger receptors associated with fatty acid uptake, inflammation, oxidative stress, lipid accumulation, lipotoxicity and fibrosis [264,266-268].

Selective compounds targeting JAK2 (AG-490/tyrphostin) [269], JAK1/2 (/baricitinib) [270,271], STAT1 (fludarabine) [272] and STAT3 (nifuroxazide, S3I-201) [273] reduced albuminuria, inflammatory infiltrate, renal damage (mesangial expansion, oxidative stress, tubular atrophy, and fibrosis) and serum amyloid A in experimental DN. New design compounds such as the bromodomain inhibitor MS417 have shown the capacity to directly target acetyl-lysine residues of STAT3 and to reduce proteinuria and kidney damage in $\mathrm{db} / \mathrm{db}$ mice [274]. Heat shock protein inhibitor geldanamycin also disrupts JAK/STAT signaling pathway and reduced renal damage in diabetic mice [256]. Several oral small-molecule inhibitors targeting JAK proteins (e.g., ruxolitinib, tofacitinib and baricitinib) to prevent STAT phosphorylation have been described as potential therapeutic targets for clinical use in autoimmune and inflammatory diseases [275]. Results from a phase II clinical trial demonstrate the efficacy of baricitinib (JAK1/2 inhibitor) to reduce albuminuria and improve inflammatory biomarkers in T2DM patients with high risk of progressive diabetic kidney disease [276].

The suppressors of cytokine signaling (SOCS) proteins are described as endogenous regulators of the JAK/STAT pathway and, therefore, a feasible therapeutic strategy for diabetic complications $[261,266,277]$. The SOCS family is comprised of eight members (SOCS1-SOCS7 and CIS), with different degrees of homology and variable N-terminal domain. The presence of the kinase inhibitory region (KIR) located at the $\mathrm{N}$-terminal region of SOCS1/3 has a powerful regulatory action 
on JAK activity and offers an opportunity to develop novel selective kinase inhibitors mimicking KIR effect [278]. Optimization of endogenous protective resources through peptidomimetics of SOCS1 could have therapeutic advantages associated with the adverse effects observed in treatments with JAK inhibitors [276] (e.g., anemia); however, for this objective, it is necessary to carry out efficacy and safety studies in humans [279]. In the diabetes context, our findings demonstrate that SOCS1 mimetics prevent the development of retinopathy and atherosclerosis in mice $[280,281]$. Different SOCS1/3 delivery systems (adenovirus and cell-permeable peptide) alleviate the albuminuria and pathological renal features observed in experimental diabetic models, reducing renal inflammation, oxidative stress, and glomerular and interstitial fibrosis [261,266,282,283]. In summary, JAK/STAT activation is a key cell-signaling pathway in DN. Targeting JAK/STAT/SOCS axis could be a selective treatment in DN patients and high inflammatory risk.

\subsection{Protein Kinase $C$}

Hyperglycemia activates metabolic pathways through the protein kinase C (PKC), a family of enzymes widely described in DN progression [8]. In DN, hyperglycemia-mediated PKC $\beta$ and PKC $\delta$ activation in the renal cortex leads to subsequent activation of NF- $\mathrm{KB}$ and release of IL-6, and TNF- $\alpha$ by endothelial and mesangial cells [284,285]. Genetic deletion of PKC $\beta$ and PKC $\delta$ decreased renal hypertrophy, podocyte apoptosis, endothelial dysfunction, fibrosis, and proteinuria in diabetic mice $[285,286]$. Similarly, pharmacological inhibition of $\mathrm{PKC} \beta$ isoform with ruboxistaurin reduced glomerular TGF- $\beta$ expression and decreased fibronectin and collagen IV deposition fibrosis in experimental DN $[287,288]$. This approach also provided renoprotective effects in several clinical trials on patients with diabetes or diabetic complications [289] (NCT00297401; NCT00044421).

\section{7. $N r f 2$}

Nrf2 (nuclear factor (erythroid-derived 2)-like 2) is a crucial protein in redox balance. Its activation triggers a powerful antioxidant response by synthesizing more than 250 genes [290]. Oxidative stress is closely linked to inflammation in diabetes mellitus and DN [291]. Nrf2 activation ameliorates pancreatic cell damage and its suppression aggravates cellular death in diabetic mice [292]. Treatment with Nrf2 activators, tert-butylhydroquinone (TBHQ) [293], bardoxolone methyl analog [294], or sulforaphane [295], reduced expression of proinflammatory cytokines and macrophage infiltration in preclinical models of DN. Furthermore, other compounds with the ability to promote Nrf2 translocation, such as omentin-1, and natural flavonoids (myricetin, hesperetin, and curcumin), improve renal function and reduces proinflammatory cytokine production in DN [296-299]. Particularly, dietary supplementation with curcumin increased the antioxidant capacity, reduced microalbuminuria and plasma MDA levels of patients with DN $[300,301]$. A number of clinical trials with Nrf2 inducers have been performed in patients with DN. This is the case of bardoxolone methyl, an oral antioxidant drug that activates Nrf2. A first 8-week study with 20 patients determined that this drug was able to increase the eGFR [302]. The continuation of this research, in a phase II study with 227 patients treated during 24 and 52 weeks, determined that this effect was maintained over time [303] (NCT00811889). A phase III trial with 2185 patients with T2DM and stage 4 CKD confirmed that bardoxolone methyl treatment increased eGFR; however, this study was interrupted because bardoxolone methyl treated patients showed an increased risk of cardiovascular events [304] (NCT01351675). Increased eGFR remained elevated for up to four weeks after cessation of treatment, suggesting a lower risk of end-stage renal disease [305]. Two Japanese clinical trials in diabetic patients with CKD are now testing the effectivity of bardoxolone (TSUBAKY NCT02316821, and AYAME NCT03550443). After an exploratory study in patients with rare kidney diseases (PHOENIX, NCT03366337), ongoing bardoxolone trials are being conducted in patients with Alport syndrome (CARDINAL, NCT03019185, and EAGLE, NCT03749447), or are recruiting patients with autosomal dominant polycystic kidney disease (FALCON, NCT03918447). 


\section{8. $p 38 / M A P K$}

P38 mitogen-activated protein kinases are a class of mitogen-activated protein kinases (MAPK) that participates in several cellular stress responses [306]. Studies in human biopsies and cell cultures stimulated with high glucose or AGEs, demonstrated activation of the p38/MAPK pathway in podocytes, tubular, and interstitial cells [306,307]. Selonsertib, a MAP3K5 (ASK1) inhibitor and sulodexide, a sulfated glycosaminoglycan, ameliorated kidney damage by targeting p38/MAPK in T1DM and T2DM preclinical models [308-310]. A phase III clinical trial with selonsertib has been recently approved in DN patients (NCT04026165).

The selected preclinical models targeting inflammatory intracellular signaling pathway and clinical trial targeting inflammation in DN are summarized in the Tables 2 and 3, respectively.

Table 2. Selected preclinical studies targeting inflammatory intracellular signaling pathways in DN.

\begin{tabular}{|c|c|c|c|c|c|}
\hline Target & Diabetic Model & Strategy & Category & Conclusion & Ref. \\
\hline \multirow{5}{*}{$\begin{array}{l}\text { NOD- like } \\
\text { receptor }\end{array}$} & $\begin{array}{l}\text { SD rats }+ \text { STZ } \\
(55 \mathrm{mg} / \mathrm{kg})\end{array}$ & $\begin{array}{l}\text { Quercetin or } \\
\text { allopurinol }\end{array}$ & $\begin{array}{l}\text { Flavonoid or } \\
\text { XO inhibitor }\end{array}$ & $\begin{array}{l}\text { Ameliorates hyperuricemia and } \\
\text { reduces IL-1 } \beta \text { and IL-18 levels. }\end{array}$ & [226] \\
\hline & $\begin{array}{l}\text { SD rats }+ \text { STZ } \\
(50 \mathrm{mg} / \mathrm{kg})\end{array}$ & $\begin{array}{l}\text { Cepharanthine } \\
\text { and Piperine }\end{array}$ & Nutraceuticals & Decreases cytokines NLRP3-dependent. & [227] \\
\hline & $\begin{array}{l}\text { ApoE-/- mice + STZ } \\
\quad(80 \mathrm{mg} / \mathrm{kg})\end{array}$ & Pioglitazone & $\operatorname{PPAR} \gamma$ agonist & $\begin{array}{l}\text { Restores renal function. Downregulates } \\
\text { AGEs, RAGEs and cytokines } \\
\text { NLRP3-dependent. }\end{array}$ & [228] \\
\hline & $\mathrm{db} / \mathrm{db}$ mice & MCC950 & $\begin{array}{l}\text { Selective NLRP3 } \\
\text { inhibitor }\end{array}$ & $\begin{array}{l}\text { Ameliorates GBM thickness, podocyte } \\
\text { injury and renal fibrosis. }\end{array}$ & [229] \\
\hline & $\mathrm{db} / \mathrm{db}$ mice & M920 & $\begin{array}{l}\text { Pan-caspase } \\
\text { inhibitor }\end{array}$ & $\begin{array}{c}\text { Reduces NLRP3-inflammasome (IL-1 } \beta \text {, } \\
\text { IL-18, NLRP3, caspase-1) and } \\
\text { profibrotic markers. }\end{array}$ & [230] \\
\hline \multirow[b]{2}{*}{ TLRs } & $\mathrm{eNOS}^{-/-}+\mathrm{STZ}$ mice & CRX-526 & TLR4 antagonist & $\begin{array}{l}\text { Ameliorates histological changes, } \\
\text { inflammatory and profibrotic markers. }\end{array}$ & [232] \\
\hline & $\mathrm{db} / \mathrm{db}$ mice & GIT27 & TLR4 inhibitor & $\begin{array}{l}\text { Reduces proinflammatory, oxidative } \\
\text { stress and lipid metabolism markers. }\end{array}$ & [233] \\
\hline \multirow{4}{*}{$\begin{array}{l}\text { PI3K/ } \\
\text { AKT }\end{array}$} & $\mathrm{SD}+\mathrm{STZ}(60 \mathrm{mg} / \mathrm{kg})$ & Rapamycin & mTOR inhibitor & $\begin{array}{l}\text { Ameliorates histological changes, } \\
\text { inflammation and fibrotic markers. }\end{array}$ & [239] \\
\hline & $\begin{array}{l}\text { C57BL/6 + STZ } \\
(60 \mathrm{mg} / \mathrm{kg})\end{array}$ & Mangiferin & $\begin{array}{c}\text { Natural phenolic } \\
\text { xanthonoid }\end{array}$ & $\begin{array}{l}\text { Reduces inflammation, oxidative stress } \\
\text { and profibrotic markers. }\end{array}$ & [240] \\
\hline & $\begin{array}{l}\text { C57BL } / 6 \mathrm{~J}+\mathrm{STZ} \\
(50 \mathrm{mg} / \mathrm{kg})\end{array}$ & Elabela & $\begin{array}{l}\text { Peptide agonist } \\
\text { Apelin/APJ } \\
\text { receptor }\end{array}$ & $\begin{array}{l}\text { Reduces GBM thickening, podocyte } \\
\text { damage, inflammation, apoptosis and } \\
\text { fibrosis markers. }\end{array}$ & [241] \\
\hline & $\begin{array}{l}\text { Wistar rats + STZ } \\
\quad(60 \mathrm{mg} / \mathrm{kg})\end{array}$ & Emodin & $\begin{array}{l}\text { Derived from } \\
\text { root rhubarb }\end{array}$ & $\begin{array}{l}\text { Attenuates inflammation, oxidative } \\
\text { stress and apoptosis markers. }\end{array}$ & [245] \\
\hline \multirow{6}{*}{ NF-кB } & $\mathrm{db} / \mathrm{db}$ mice & Celastrol & $\begin{array}{l}\text { Celastrus regelii } \\
\text { root extracts }\end{array}$ & $\begin{array}{l}\text { Improves lipid accumulation, oxidative } \\
\text { stress and proinflammatory markers. }\end{array}$ & [248] \\
\hline & $\mathrm{db} / \mathrm{db}$ mice & miR-451 & LMP7 modulator & $\begin{array}{l}\text { Decreases histological lesions, } \\
\text { inflammation and fibrosis markers. }\end{array}$ & [249] \\
\hline & $\begin{array}{l}\text { Wistar rats + STZ } \\
\quad(65 \mathrm{mg} / \mathrm{kg})\end{array}$ & Berberine & Flavonoid & $\begin{array}{l}\text { Improves systemic and renal cortex } \\
\text { inflammatory response. }\end{array}$ & [250] \\
\hline & $\begin{array}{l}\text { SD rats }+ \text { STZ } \\
(50 \mathrm{mg} / \mathrm{kg})\end{array}$ & BAY 11-7082 & $\begin{array}{l}\text { Phospho-IкB } \\
\text { inhibitor }\end{array}$ & $\begin{array}{l}\text { Reduces proinflammatory cytokines } \\
\text { and oxidative stress markers. }\end{array}$ & [252] \\
\hline & $\begin{array}{l}\text { ApoE }{ }^{-/-} \text {mice }+ \text { STZ } \\
(125 \mathrm{mg} / \mathrm{kg}-2 \text { days })\end{array}$ & NBD peptide & $\begin{array}{l}\text { Mimetic } \\
\text { IKK } \beta-N E M O \\
\text { complex }\end{array}$ & $\begin{array}{l}\text { Decreases histological lesions, } \\
\text { inflammation and fibrosis. }\end{array}$ & [254] \\
\hline & $\begin{array}{l}\text { SD rats }+ \text { STZ } \\
(50 \mathrm{mg} / \mathrm{kg})\end{array}$ & $\begin{array}{l}\text { Nilotinib } \\
\text { hydrochloride }\end{array}$ & $\begin{array}{l}\text { BCR-ABL } \\
\text { tyrosine kinase } \\
\text { inhibitor }\end{array}$ & $\begin{array}{l}\text { Reduces oxidative stress, inflammation } \\
\text { and profibrotic marker expression. }\end{array}$ & [255] \\
\hline
\end{tabular}


Table 2. Cont

\begin{tabular}{|c|c|c|c|c|c|}
\hline Target & Diabetic Model & Strategy & Category & Conclusion & Ref. \\
\hline \multirow{6}{*}{$\begin{array}{l}\text { JAK/ } \\
\text { STAT }\end{array}$} & $\begin{array}{l}\text { SD rats }+ \text { STZ } \\
(60 \mathrm{mg} / \mathrm{kg})\end{array}$ & $\begin{array}{c}\text { AG-490 } \\
\text { (Tyrphostin) }\end{array}$ & JAK 2 inhibitor & $\begin{array}{l}\text { Prevents JAK2 and STATs } \\
\text { phosphorylation. }\end{array}$ & [269] \\
\hline & $\begin{array}{l}\text { Akita mice + JAK2 } \\
\text { Pod-overexpression }\end{array}$ & $\begin{array}{l}\text { Tyrphostin or } \\
\text { Baricitinib }\end{array}$ & JAK 2 inhibitors & $\begin{array}{c}\text { Ameliorates histological changes, } \\
\text { serum amyloid A3 plasma and kidney } \\
\text { tissue. }\end{array}$ & {$[228,229]$} \\
\hline & $\begin{array}{l}\text { SD rats }+ \text { STZ } \\
(50 \mathrm{mg} / \mathrm{kg})\end{array}$ & Nifuroxazide & STAT3 inhibitor & $\begin{array}{l}\text { Diminishes inflammatory and } \\
\text { profibrotic factors and infiltrating cells. }\end{array}$ & [273] \\
\hline & $\begin{array}{l}\text { Double } \mathrm{db} / \mathrm{db}- \\
\text { SIRT-1 }{ }^{-/-} \text {mice }\end{array}$ & MS417 & $\begin{array}{l}\text { BET-specific } \\
\text { BRD4 inhibitor }\end{array}$ & $\begin{array}{l}\text { Attenuates histological changes and } \\
\text { STAT3 activity. }\end{array}$ & [274] \\
\hline & $\begin{array}{l}\text { CD-1 mice + STZ } \\
(150 \mathrm{mg} / \mathrm{kg})\end{array}$ & $\begin{array}{l}\text { Gene delivery } \\
\text { SOCS1 }\end{array}$ & $\begin{array}{c}\text { SOCS1 } \\
\text { Overexpression }\end{array}$ & $\begin{array}{l}\text { Attenuates renal hypertrophy, } \\
\text { inflammation and profibrotic markers. }\end{array}$ & [282] \\
\hline & $\begin{array}{l}\text { ApoE }^{-/-}+\mathrm{STZ} \\
(125 \mathrm{mg} / \mathrm{kg})\end{array}$ & $\begin{array}{l}\text { SOCS1 } \\
\text { delivery } \\
\text { system }\end{array}$ & $\begin{array}{l}\text { Mimetic SOCS1- } \\
\text { KIR region }\end{array}$ & $\begin{array}{l}\text { Reduces atherosclerosis, structural } \\
\text { changes and inflammatory markers. }\end{array}$ & {$[219,241]$} \\
\hline \multirow[b]{2}{*}{ PKC } & $\begin{array}{l}\text { Wistar rats + STZ } \\
\quad(55 \mathrm{mg} / \mathrm{kg})\end{array}$ & Ruboxistaurin & $\begin{array}{l}\text { Selective PKC } \beta \\
\text { inhibitor }\end{array}$ & $\begin{array}{l}\text { Improves histological changes and } \\
\text { attenuates TGF } \beta / S m a d 2 / 3 \text { pathway. }\end{array}$ & [287] \\
\hline & $\begin{array}{l}\text { Swiprosin- } 1^{-/-} \\
\text {C57BL } / 6 \text { mice }+ \text { STZ } \\
(150 \mathrm{mg} / \mathrm{kg})\end{array}$ & Ruboxistaurin & $\begin{array}{l}\text { Selective PKC } \beta \\
\text { inhibitor }\end{array}$ & $\begin{array}{l}\text { Ameliorates histological changes, } \\
\text { apoptosis and Swiprosin-1 expression. }\end{array}$ & [288] \\
\hline \multirow{7}{*}{ Nrf2 } & $\begin{array}{l}\text { SD rats + IR injury + } \\
\text { STZ }(65 \mathrm{mg} / \mathrm{kg})\end{array}$ & TBHQ & $\begin{array}{l}\text { Synthetic } \\
\text { antioxidant }\end{array}$ & $\begin{array}{l}\text { Ameliorates oxidative stress, } \\
\text { inflammation and apoptosis. }\end{array}$ & [293] \\
\hline & $\begin{array}{l}\mathrm{db} / \mathrm{db} \text { and } \mathrm{C} 57 \mathrm{BL} / 6 \\
\text { mice }+\mathrm{HFD}\end{array}$ & $\begin{array}{l}\gamma \text {-glutamyl } \\
\text { transpeptidase }\end{array}$ & $\begin{array}{l}\text { Bardoxolone } \\
\text { methyl analog }\end{array}$ & $\begin{array}{l}\text { Reduces body weight, histological } \\
\text { changes and GBM thickening. }\end{array}$ & [294] \\
\hline & $\begin{array}{l}\text { Wistar rats + STZ } \\
\quad(58 \mathrm{mg} / \mathrm{kg})\end{array}$ & Sulforaphane & $\begin{array}{l}\text { Cruciferous } \\
\text { vegetables } \\
\text { extracts }\end{array}$ & $\begin{array}{l}\text { Diminishes inflammation, oxidative } \\
\text { stress markers, DNA damage and cell } \\
\text { death. }\end{array}$ & [295] \\
\hline & $\begin{array}{l}\text { SD rats }+ \text { STZ } \\
(60 \mathrm{mg} / \mathrm{kg})\end{array}$ & Hesperetin & Flavonoid & $\begin{array}{l}\text { Ameliorates histological changes, } \\
\text { inhibition AGEs/RAGE axis and } \\
\text { inflammation. }\end{array}$ & [296] \\
\hline & $\begin{array}{c}\text { C57BL } / 6+\mathrm{STZ} \\
(50 \mathrm{mg} / \mathrm{kg}) \text { and Nrf2 } \\
\text { knockdown mice }\end{array}$ & Myricetin & Flavonoid & $\begin{array}{l}\text { Mitigates inflammation, oxidative stress } \\
\text { and fibrosis markers. }\end{array}$ & [297] \\
\hline & $\mathrm{db} / \mathrm{db}$ mice & Omentin-1 & Adipokine & $\begin{array}{l}\text { Reduces proinflammatory cytokines } \\
\text { and oxidative stress markers. }\end{array}$ & [298] \\
\hline & $\begin{array}{l}\text { SD rats }+ \text { STZ } \\
(55 \mathrm{mg} / \mathrm{kg})\end{array}$ & Curcumin & Flavonoid & $\begin{array}{l}\text { Lipid accumulation, angiogenesis, } \\
\text { profibrotic and podocyte damage } \\
\text { markers. }\end{array}$ & [299] \\
\hline \multirow{3}{*}{$\begin{array}{c}\text { p38/ } \\
\text { MAPK }\end{array}$} & $\begin{array}{l}\mathrm{eNOS}^{-/-} \text {mice }+ \text { STZ } \\
\quad(55 \mathrm{mg} / \mathrm{kg})\end{array}$ & GS-444217 & \multirow{2}{*}{$\begin{array}{l}\text { ASK1 inhibitor } \\
\text { (Selonsertib) }\end{array}$} & \multirow{2}{*}{$\begin{array}{l}\text { Ameliorates histological changes, } \\
\text { inflammatory and profibrotic markers. }\end{array}$} & [308] \\
\hline & $\mathrm{eNOS}^{-/-} \mathrm{db} / \mathrm{db}$ mice & $\begin{array}{l}\text { GS-444217 + } \\
\text { ACEi }\end{array}$ & & & [309] \\
\hline & OLETF rats & Sulodexide & Sulfated GAGs & $\begin{array}{l}\text { Reduces histological changes, urinary } \\
\text { VEGF and profibrotic markers. }\end{array}$ & [310] \\
\hline
\end{tabular}

Abbreviations: STZ: streptozotocin; SD: Sprague Dawley; OLEFT: Otsuka Long-Evans Fatty Tokushima, NBD: NEMO-binding domain; SOCS: suppressor of cytokine signaling; TBHQ: tert-butylhydroquinone; ACEi: angiotensin-converting enzyme inhibitor; PPAR $\gamma$ : peroxisome proliferator-activated receptor gamma; XO: xanthine oxidase; LMP7: low-molecular mass protein-7; NEMO: NF-KB essential modulator; BET: bromodomains and extraterminal motif; BRD4: bromodomain containing 4: ASK1: apoptosis signal-regulating kinase 1; GAGs: glycosaminoglycans: GBM: glomerular basal membrane. 
Table 3. Selected clinical trials targeting inflammation in DN.

\begin{tabular}{|c|c|c|c|c|c|c|}
\hline Target & Compound & Enrollment & Phase & Status & 1stor 2nd Outcome & Identification \\
\hline Chymase inhibitor & BAY1142524 Fulacimstat & 152 & 2 & C & UACR & NCT03412006 \\
\hline VAP-1 inhibitor & ASP8232 & 55 & 2 & C & AE-UACR & NCT02218099 \\
\hline Galectin-3 antagonist & GCS-100 & 375 & 2 & $\mathrm{U}$ & eGFR & NCT02312050 \\
\hline $\begin{array}{l}\text { Anti-Human } \\
\alpha V \beta 3\end{array}$ & $\begin{array}{c}\text { VPI-2690B } \\
\text { Monoclonal antibody }\end{array}$ & 165 & 2 & C & Albuminuria-eGFR & NCT02251067 \\
\hline CCL2 inhibitor & AF2838 Bindarit & 100 & 2 & $\mathrm{C}$ & UACR & NCT01109212 \\
\hline CCL2 inhibitor & Spiegelmer ${ }^{\circledR}$ NOX-E36 & 76 & 2 & $\mathrm{C}$ & UACR & NCT01547897 \\
\hline CCR2 inhibitor & Propagermanium & 45 & 2 & A & UACR—eGFR & NCT03627715 \\
\hline CCR2 inhibitor & CCX140-B & 332 & 2 & C & UACR & NCT01447147 \\
\hline CCR2/5 antagonist & PF-04634817 & 226 & 2 & $\mathrm{C}$ & UACR & NCT01712061 \\
\hline CCR2/5 antagonist & BMS-813160 & 319 & 2 & $\mathrm{~T}$ & UACR & NCT01752985 \\
\hline PDE inhibitor & Pentoxifylline & 196 & 4 & $\mathrm{R}$ & eGFR & NCT03664414 \\
\hline PDE inhibitor & Pentoxifylline & 2510 & 4 & A & Death-ESRD—UACR & NCT03625648 \\
\hline Anti-Human IL-1 $\beta$ & Canakinumab & 10066 & 3 & $\mathrm{C}$ & MACE-UACR-eGFR & NCT01327846 \\
\hline $\begin{array}{l}\text { Anti-Human } \\
\text { IL-18 }\end{array}$ & $\begin{array}{c}\text { GSK1070806 } \\
\text { Monoclonal antibody }\end{array}$ & 37 & 2 & C & $\begin{array}{l}\mathrm{UACR}, \mathrm{HbA} 1 \mathrm{c} \text { and } \\
\text { metabolic changes }\end{array}$ & NCT01648153 \\
\hline $\begin{array}{l}\text { Anti-Human } \\
\text { IL-33 }\end{array}$ & $\begin{array}{c}\text { MEDI3506 } \\
\text { Monoclonal Antibody }\end{array}$ & 168 & 2 & $\mathrm{R}$ & UACR & NCT04170543 \\
\hline $\begin{array}{l}\text { Anti-Human } \\
\text { TGF } \beta 1\end{array}$ & $\begin{array}{c}\text { Galunisertib } \\
\text { Monoclonal Antibody }\end{array}$ & 417 & 2 & $\mathrm{~T}$ & UACR & NCT01113801 \\
\hline Anti-Human TGF $\alpha /$ Epiregulin & $\begin{array}{c}\text { LY3016859 } \\
\text { Monoclonal antibody }\end{array}$ & 60 & 2 & C & UACR & NCT01774981 \\
\hline JAK2 inhibitor & Baricitinib & 130 & 2 & $\mathrm{C}$ & UACR-eGFR & NCT01703234 \\
\hline PKC $\beta$ Inhibitor & Ruboxistaurin & 20 & 3 & $\mathrm{C}$ & UACR & NCT00297401 \\
\hline NRF2 inducer & Bardoxolone Methyl & 1323 & 3 & A & eGFR or ESRD & NCT03550443 \\
\hline NRF2 inducer & Bardoxolone Methyl & 2185 & 3 & C & ESRD or death & NCT01351675 \\
\hline NRF2 inducer & Bardoxolone Methyl & 216 & 2 & C & AE-eGFR & NCT02316821 \\
\hline Anti-inflammatory inhibitor & Colchicine & 160 & NA & A & UACR & NCT02035891 \\
\hline Sulfated GAGs & KRX-101 Sulodexide & 1248 & 4 & $\mathrm{~T}$ & ESRD-UACR & NCT00130312 \\
\hline ASK-1 inhibitor & GS-4997 Selonsertib & 3300 & 3 & A & eGFR-ESRD & NCT04026165 \\
\hline
\end{tabular}

Abbreviations: A: active; AE: adverse effects; C: completed; NA: not applicable; NR: not yet recruiting; R: recruiting; T: terminated; U: unknown. UACR: urinary albumin creatinine ratio; eGFR: estimated glomerular filtration rate; ESRD: end-stage renal disease; MACE: major adverse cardiovascular events; ERPF: effective renal plasma flow. 


\section{Novel Antidiabetic Drugs with Anti-Inflammatory Actions in DN}

Sodium-glucose cotransporter-2 (SGLT2) inhibitors reduce renal tubular glucose reabsorption, decreasing diabetes-associated hyperglycemia [311]. Recent clinical trials have demonstrated that new class of oral glucose-lowering therapy improved renal and cardiovascular outcomes of T2DM patients [312,313]. Recent data have also suggested that SGLT2 inhibitors (SGLT2i) possess beneficial actions against inflammatory response in DN. Preclinical models Akita or $\mathrm{db} / \mathrm{db}$ mice treated with dapagliflozin reduced macrophage infiltration in the kidney and decreased inflammatory factors, such as TGF- $\beta$, CCL2, osteopontin, and ICAM-1 [314]. In $\mathrm{db} / \mathrm{db}$ mice, the use of empaglifozin reduced renal inflammation determined by the reduction of NF- $\mathrm{KB}, \mathrm{CCL} 2$, IL-6 levels and immune cell infiltration [315]. In the clinical field, some studies were developed about the role of SGLT2i in diabetic patients. The EMPA-REG OUTCOME (NCT01131676) trial in T2DM patients at high risk of CVD, described that the treatment with empagliflozin diminished the incidence DN and the loss of renal function [312]. The CANTATA-SU (NCT00968812) study in T2DM patients treated with metformin and canagliflozin, showed a reduction in TNFR1, IL-6, metalloproteinase-7 and fibronectin-1 levels, suggesting that canagliflozin contributes to reverse molecular processes related to inflammation, extracellular matrix turnover and fibrosis [316].

Another pillar of current treatment for diabetes is based on incretin modulators [317]. Dipeptidyl peptidase-4 inhibitors (DPP4i) are effective for the treatment of residual proteinuria in DN, a fact that is evidenced in a recent meta-analysis of the effects of sitagliptin in T2DM patients [318]. Sitagliptin also display in vitro and in vivo nephroprotective actions, including antioxidant [319,320], lipotoxicity-mediated inflammation [321] and antifibrotic actions [322].

GLP-1 receptor agonists (GLP-1 RA) are used in the metabolic control of obesity and T2DM patients because they enhance glucose-dependent insulin synthesis and secretion, proliferation of $\beta$-cells, inhibition of $\beta$-cells apoptosis, delay of gastric emptying and regulation of appetite by satiety-effects with body weight reduction [323-325]. GLP-1 RA reduces albuminuria and histological renal damage [326], and downregulates genes related to inflammation (NF- $\mathrm{kB}, \mathrm{TNF}-\alpha, \mathrm{MCP}-1)$ [327], oxidative stress (Nox4 and subunits gp91phox, p22phox, p47phox) [328], de novo lipogenesis/lipotoxicity (SREBP-1; ABCA1) [329] and fibrosis ( $\alpha$-SMA, fibronectin, collagen I) [330]. These renoprotective effects observed in T2DM and CKD patients have been validated by four major clinical trials AWARD-7 [331], LEADER [332], SUSTAIN-6 [333] and ELIXA [334]. In brief, these novel antidiabetic drugs have had a tremendous impact on the treatment of cardiovascular and renal complications of diabetic patients, there exist hundreds of publications, and they have been incorporated as recommendations in all clinical guides (Table 4). 
Table 4. Novel antidiabetic drugs with anti-inflammatory actions in patients with DN.

\begin{tabular}{|c|c|c|c|c|c|c|}
\hline Target & Compound & Enrollment & Phase & Status & 1st or 2nd Outcome & Identification \\
\hline SGLT2i & Empaglifozin & 70 & 4 & $\mathrm{R}$ & Albuminuria-eGFR & NCT04127084 \\
\hline SGLT2i & Empaglifozin & 7064 & 3 & $\mathrm{C}$ & MACE and UACR & NCT01131676 \\
\hline SGLT2i + DPP-4i & Empaglifozin + Linagliptin & 66 & 4 & $\mathrm{R}$ & eGFR-UACR & NCT03433248 \\
\hline SGLT2i + GLP-1 RA & Empaglifozin + Semaglutide & 80 & 4 & NR & Albuminuria-eGFR & NCT04061200 \\
\hline SGLT2i & Canagliflozin & 4401 & 3 & $\mathrm{C}$ & eGFR-ESRD & NCT02065791 \\
\hline SGLT2i & Canagliflozin & 300 & 3 & $\mathrm{~A}$ & eGFR-UACR & NCT03436693 \\
\hline SGLT2i & Canaglifozin & 1452 & 3 & $\mathrm{C}$ & HbA1c change & NCT00968812 \\
\hline SGLT2i & Dapagliflozine & 44 & 4 & $\mathrm{C}$ & eGFR-ERPF-UACR & NCT02682563 \\
\hline DPP-4i & Linagliptin & 48 & 4 & $\mathrm{C}$ & eGFR-ERPF & NCT02106104 \\
\hline DPP-4i & Linagliptin & 6991 & 4 & $\mathrm{C}$ & MACE-eGFR & NCT01897532 \\
\hline DPP-4i & Alogliptin & 5380 & 3 & $\mathrm{C}$ & MACE & NCT00968708 \\
\hline DPP-4i & Saxagliptin & 18206 & 4 & $\mathrm{C}$ & MACE & NCT01107886 \\
\hline DPP-4i & Sitagliptin & 14671 & 3 & $\mathrm{C}$ & MACE-eGFR & NCT00790205 \\
\hline GLP-1 RA & Lixisenatide & 40 & 4 & $\mathrm{C}$ & eGFR-ERPF & NCT02276196 \\
\hline GLP-1 RA & Exenatide & 92 & 4 & $\mathrm{C}$ & Albuminuria & NCT02690883 \\
\hline GLP-1 RA & Dulaglutide & 577 & 3 & $\mathrm{C}$ & $\mathrm{HbA1c}-\mathrm{eGFR}-\mathrm{UACR}$ & NCT01621178 \\
\hline GLP-1 RA & Liraglutide & 9341 & 3 & $\mathrm{C}$ & MACE and UACR & NCT01179048 \\
\hline GLP-1 RA & Semaglutide & 3297 & 3 & $\mathrm{C}$ & MACE-HbA1c-UACR & NCT01720446 \\
\hline GLP-1 RA & Lixisenatide & 6068 & 3 & $\mathrm{C}$ & MACE-UACR & NCT01147250 \\
\hline
\end{tabular}

Abbreviations: A: active; C: completed; NR: not yet recruiting; R: recruiting; UACR: urinary albumin creatinine ratio; eGFR: estimated glomerular filtration rate; ESRD: end-stage renal disease; MACE: major adverse cardiovascular events; ERPF: effective renal plasma flow 


\section{Perspectives and Conclusions}

$\mathrm{DN}$ is one of the most leading causes of CKD/ESRD. Established treatment for patients with diabetes includes control of blood glucose, cholesterol and hypertension, but provide incomplete protection against ESRD and cardiovascular risk. There is, therefore, an urgent need to apply more effective therapies for patients with DN.

Targeting inflammation may be useful in the prevention and treatment of DN. In this sense, the inhibition of IL-1 $\beta$ activity (gevokizumab, anakinra and canakinumab) and the blockade of CCL2 (AF2838) and their receptors CCR2/CCR5 (CCX140-B, PF-04634817, BMS-813160) open a new horizon for the employment of anti-inflammatory therapies in patients $\mathrm{DN}$, including those with cardiovascular risk. The blockade of some adhesion molecules (Galectin-3, $\alpha \mathrm{V} \beta 3$ ) has also provided beneficial effects in DN. NLRP3 inflammasome and its related cytokine IL-18 have emerged as important inflammatory molecules involved in the progression of DN. However, no compounds targeting inflammasome components have been yet tested in clinical trials. Although Th17 response has gained attention in the last years, there are controversial results about its role in DN. On the other hand, oxidative stress is closely related to inflammation in DN. Several clinical reports suggest that activation of the Nrf2 pathway, mainly with bardoxolone, may be of interest.

As discussed in this review, several urinary and plasma inflammatory biomarkers have been examined at early and advanced stages DN. These biomarkers can be associated to glomerular and tubular damage, oxidative stress, and fibrosis development [335]. Moreover, some inflammatory markers (TNF $\alpha$, IL-6 and CCL2) and adipokines (resistin, visfatin and leptin) detected in the saliva of T2DM patients could have a prognostic value on the progression of $\mathrm{DN}$, given their high correlation with serum/urinary inflammatory markers $[336,337]$. The refinement of -omic techniques and novel bioinformatic platforms predict an exponential growth in this area, both in the diagnosis and categorization of DN.

In conclusion, emerging therapies for DN are focused on the modulation of inflammatory pathways that control the functional and structural abnormalities in DN. Compounds targeting some chemokines and their receptors, cytokines, NF-KB, NLRP3 inflammasome, PI3K/Akt and JAK/STAT pathways, and the Nrf2-regulated antioxidant defense have shown remarkable efficacy in preclinical studies. In this regard, some incipient clinical trials (e.g., baricitinib, canakinumab) have afforded promising results in patients with DN. Therefore, although recent clinical trials with SGLT2i and GLP-1 RA have provided beneficial effects in patients with $\mathrm{DN}$, additional specific anti-inflammatory strategies may be of special interest to further reduce residual proteinuria and progression to renal failure. Further research is needed to find the balance between the benefits and potential risks of these incoming therapies, and to identify the subgroups of patients most likely to benefit from them.

Funding: The authors work has been supported by grants from Instituto de Salud Carlos III (ISCIII, FIS-FEDER PI17/00130, PI17/01495, PI19/00588, ERA-PerMed-JTC2018-PERSTIGAN AC18/00071), Spanish Biomedical Research Centre in Diabetes and Associated Metabolic Disorders (CIBERDEM) and Cardiovascular (CIBERCV), Fondecyt Project (No. 1160465), Spanish Ministry of Science and Innovation (RTI2018-098788-B-100, DTS17/00203, DTS19/00093, RYC-2017-22369), and Spanish Societies of Cardiology (SEC), Nephrology (SEN) and Atherosclerosis (SEA). The "PFIS" and "Sara Borrell" training program of the ISCIII supported the salary of MGH (FI18/00310), SR-M (CD19/00021) and CH-B (CP16/00017). Córdoba University supported the salary of C.G.C. No other relevant affiliations or financial involvement exist with any organization or entity with a financial interest in or financial conflict with the subject matter or materials discussed in the manuscript. This includes employment, consultancies, honoraria, stock ownership or options, expert testimony, grants or patents received or pending, or royalties.

Conflicts of Interest: The authors declare no conflict of interest. The funders had no role in the design of the study; in the collection, analyses, or interpretation of data; in the writing of the manuscript, or in the decision to publish the results. 


\section{Abbreviations}

\begin{tabular}{|c|c|}
\hline ABCA1 & ATP binding cassette transporter A1 \\
\hline ACEi & Angiotensin-converting-enzyme inhibitors \\
\hline AGEs & Advanced glycation end-products \\
\hline Akt & Protein kinase B \\
\hline ApoE & Apolipoprotein E \\
\hline AP-1 & Activator protein-1 \\
\hline ARBs & Angiotensin Receptor Blockers \\
\hline ASK1 & Apoptosis signal-regulating kinase 1 \\
\hline BMP-7 & Bone morphogenetic protein 7 \\
\hline BTBR & Black and tan brachyuric \\
\hline BUN & Blood urea nitrogen \\
\hline CASP1 & Caspase-1 \\
\hline CCL11 & Chemokine-CC motif ligand 11 \\
\hline CCL2 & Chemokine-CC motif ligand 2 \\
\hline CCL5 & Chemokine-CC motif ligand 5 \\
\hline CCR2 & $\mathrm{C}-\mathrm{C}$ chemokine receptor 2 \\
\hline CCR5 & $\mathrm{C}-\mathrm{C}$ chemokine receptor 5 \\
\hline CD206/MRC1 & Mannose receptor \\
\hline CD4+ & Cluster of differentiation $4+$ \\
\hline CD74 & Cluster of differentiation 74 \\
\hline CD8+ & Cluster of differentiation $8+$ \\
\hline CKD & Chronic kidney disease \\
\hline Col IV & Collagen IV \\
\hline CVD & Cardiovascular Disease \\
\hline CX3CL1 & Fractalkine \\
\hline CX3CR1 & Fractalkine receptor \\
\hline CXCL1 & Chemokine (C-X-C motif) ligand 1 \\
\hline CXCL10 & Chemokine (C-X-C motif) ligand 10 \\
\hline CXCL12 & Chemokine (C-X-C motif) ligand 12 \\
\hline CXCL16 & Chemokine (C-X-C motif) ligand 16 \\
\hline CXCL5 & Chemokine (C-X-C motif) ligand 5 \\
\hline CXCL8 & Chemokine (C-X-C motif) ligand 8 \\
\hline CXCL9 & Chemokine (C-X-C motif) ligand 9 \\
\hline CXCR4 & C-X-C chemokine receptor type 4 \\
\hline $\mathrm{db} / \mathrm{db}$ & Diabetic/diabetic \\
\hline DCs & Dendritic cells \\
\hline $\mathrm{DN}$ & Diabetic nephropathy \\
\hline DNA & Deoxyribonucleic acid \\
\hline DPP4i & Dipeptidyl peptidase- 4 inhibitors \\
\hline eGFR & Estimated glomerular filtration rate \\
\hline EMT & Epithelial to mesenchymal transition \\
\hline EndMT & Endothelial to mesenchymal transition \\
\hline ERK $1 / 2$ & Extracellular Signal-Regulated Kinase 1/2 \\
\hline ESRD & End-stage renal disease \\
\hline FGF1 & Acidic fibroblast growth factor \\
\hline GBM & Glomerular basement membrane \\
\hline GLP-1 & Glucagon-Like Peptide 1 \\
\hline GLP-1 RA & GLP-1 receptor agonists \\
\hline GSK-3 $\beta$ & Glycogen synthase kinase $3 \beta$ \\
\hline $\mathrm{HbA1c}$ & Hemoglobin A1c \\
\hline HK-2 & Human kidney 2 cells \\
\hline $\mathrm{HO}-1$ & Heme Oxygenase 1 \\
\hline
\end{tabular}




\begin{tabular}{|c|c|}
\hline ICAM-1 & Intercellular adhesion molecule-1 \\
\hline IFN- $\gamma$ & Interferon- $\gamma$ \\
\hline IgG & Immunoglobulin $\mathrm{G}$ \\
\hline $\operatorname{IgM}$ & ImmunoglobulinM \\
\hline $\mathrm{IKK} \alpha / \beta / \gamma$ & IкB kinase $\alpha / \beta / \gamma$ \\
\hline IL-10 & Interleukin-10 \\
\hline IL-17A/F & Interleukin-17A/F \\
\hline IL-18 & Interleukin-18 \\
\hline IL-1 $\beta$ & Interleukin-1 $\beta$ \\
\hline IL-2 & Interleukin-2 \\
\hline IL-20 & Interleukin-20 \\
\hline IL-6 & Interleukin-6 \\
\hline IL-8 & Interleukin-8 \\
\hline IP-10 & Interferon-inducible protein 10 \\
\hline JAK & Janus Kinase/ Just Another Kinase \\
\hline KIR & Kinase inhibitory region \\
\hline KRIS & Risk inflammatory signature \\
\hline LDL & Low Density Lipoprotein \\
\hline Ly6C & Lymphocyte antigen 6C \\
\hline $\mathrm{mAb}$ & Monoclonal Antibody \\
\hline MAP3K5 & Mitogen-activated protein kinase 5 \\
\hline MAPK & Mitogen-Activated Protein Kinase \\
\hline MDA & Malondialdehyde \\
\hline MEK & Mitogen-activated protein kinase kinase \\
\hline MIF & Macrophage migration inhibitory factor \\
\hline MIP-1 & Macrophage Inflammatory Protein-1 \\
\hline MMP & Matrix metalloproteinase \\
\hline mTOR & Mammalian target of rapamycin \\
\hline NADPH & Nicotinamide adenine dinucleotide phosphate hydrogen \\
\hline NBD & Nucleotide-binding domain \\
\hline NF- $\kappa \mathrm{B}$ & Nuclear factor kappa-light-chain-enhancer of activated B cells \\
\hline NLR & Nucleotide-binding oligomerization domain (NOD)-like receptors \\
\hline NLRP & Pyrin domain-containing protein \\
\hline NOD1 & Nucleotide-binding oligomerization domain-containing protein 1 \\
\hline NOD2 & Nucleotide-binding oligomerization domain-containing protein 2 \\
\hline NOX-4 & NADPH oxidase 4 \\
\hline Nrf2 & Nuclear factor (erythroid-derived 2)-like 2 \\
\hline $\mathrm{Ob}$ & obese \\
\hline P38/MAPK & p38 mitogen-activated protein kinase \\
\hline p53 & Cellular tumor antigen p53 \\
\hline PDGF & Platelet derived growth factor \\
\hline PI3K & Phosphatidylinositol 3-kinase \\
\hline PKC & Protein kinase $\mathrm{C}$ \\
\hline PPAR- $\gamma$ & Peroxisome proliferator-activated receptor- $\gamma$ \\
\hline PTEN & Phosphatase and tensin homolog \\
\hline PTX3 & Pentraxin 3 \\
\hline RAAS & Renin—angiotensin—aldosterone system \\
\hline ROS & Reactive Oxygen Species \\
\hline SGLT2 & Sodium-glucose cotransporter-2 \\
\hline SGLT2i & SGLT2 inhibitors \\
\hline sICAM-1 & Soluble intercellular adhesion molecule- 1 \\
\hline Smad & Mothers against decapentaplegic homolog \\
\hline SOCS & Suppressors of cytokine signaling \\
\hline SREBP-1 & Sterol regulatory element binding transcription factor 1 \\
\hline STAT & Signal Transducer and Activator of Transcription \\
\hline STWEAK & Soluble TNF-related weak inducer of apoptosis \\
\hline
\end{tabular}




$\begin{array}{ll}\text { STZ } & \text { Streptozotocin } \\ \text { T1DM } & \text { Type } 1 \text { and type } 2 \text { diabetes mellitus } \\ \text { T2DM } & \text { Type } 2 \text { diabetes mellitus } \\ \text { TBHQ } & \text { Tert-butylhydroquinone } \\ \text { TGF- } \beta & \text { Transforming growth factor- } \beta \\ \text { Th1 } & \text { T helper cell type } 1 \\ \text { Th17 } & \text { T helper cell type } 17 \\ \text { Th2 } & \text { T helper cell type } 2 \\ \text { TLRs } & \text { Toll-like receptors } \\ \text { TNF- } \alpha & \text { Tumor necrosis factor- } \alpha \\ \text { TNFR1 } & \text { Tumor necrosis factor receptor } 1 \\ \text { TNFR2 } & \text { Tumor necrosis factor receptor 2 } \\ \text { Tregs } & \text { Regulatory T cells } \\ \text { TYK2 } & \text { Tyrosine kinase } 2 \\ \text { UACR } & \text { Urine albumin to creatinine ratio } \\ \text { VAP-1 } & \text { Vascular adhesion protein-1 } \\ \text { VCAM-1 } & \text { Vascular cell adhesion molecule-1 } \\ \text { VEGF } & \text { Vascular endothelial growth factor } \\ \text { VEGFR2 } & \text { Vascular endothelial growth factor receptor 2 } \\ \text { ZSF1 } & \text { Zucker Diabetic Fatty 1 } \\ \alpha-S M A & \alpha \text {-smooth muscle actin }\end{array}$

\section{References}

1. Bell, S.; Fletcher, E.H.; Brady, I.; Looker, H.C.; Levin, D.; Joss, N.; Traynor, J.P.; Metcalfe, W.; Conway, B.; Livingstone, S.; et al. End-stage renal disease and survival in people with diabetes: A national database linkage study. QJM 2015, 108, 127-134. [CrossRef] [PubMed]

2. Alicic, R.Z.; Rooney, M.T.; Tuttle, K.R. Diabetic kidney disease: Challenges, progress, and possibilities. Clin. J. Am. Soc. Nephrol. 2017, 12, 2032-2045. [CrossRef] [PubMed]

3. Porrini, E.; Ruggenenti, P.; Mogensen, C.E.; Barlovic, D.P.; Praga, M.; Cruzado, J.M.; Hojs, R.; Abbate, M.; de Vries, A.P.J. ERA-EDTA diabesity working group Non-proteinuric pathways in loss of renal function in patients with type 2 diabetes. Lancet Diabetes Endocrinol. 2015, 3, 382-391. [CrossRef]

4. Anders, H.-J.; Huber, T.B.; Isermann, B.; Schiffer, M. CKD in diabetes: Diabetic kidney disease versus nondiabetic kidney disease. Nat. Rev. Nephrol. 2018, 14, 361. [CrossRef] [PubMed]

5. National Kidney Foundation. KDOQI Clinical Practice Guideline for Diabetes and CKD: 2012 Update. Am. J. Kidney Dis. 2012, 60, 850-886. [CrossRef] [PubMed]

6. Fried, L.F.; Emanuele, N.; Zhang, J.H.; Brophy, M.; Conner, T.A.; Duckworth, W.; Leehey, D.J.; McCullough, P.A.; O'Connor, T.; Palevsky, P.M.; et al. Combined angiotensin inhibition for the treatment of diabetic nephropathy. N. Engl. J. Med. 2013, 369, 1892-1903. [CrossRef]

7. Goldszmid, R.S.; Trinchieri, G. The price of immunity. Nat. Immunol. 2012, 13, 932-938. [CrossRef]

8. Schena, F.P.; Gesualdo, L. Pathogenetic mechanisms of diabetic nephropathy. J. Am. Soc. Nephrol. 2005, 16, S30-S33. [CrossRef]

9. Wada, J.; Makino, H. Innate immunity in diabetes and diabetic nephropathy. Nat. Rev. Nephrol. 2016, $12,13$. [CrossRef]

10. Niewczas, M.A.; Pavkov, M.E.; Skupien, J.; Smiles, A.; Md Dom, Z.I.; Wilson, J.M.; Park, J.; Nair, V.; Schlafly, A.; Saulnier, P.-J.; et al. A signature of circulating inflammatory proteins and development of end-stage renal disease in diabetes. Nat. Med. 2019, 25, 805-813. [CrossRef]

11. Navarro-González, J.F.; Mora-Fernández, C. The role of inflammatory cytokines in diabetic nephropathy. J. Am. Soc. Nephrol. 2008, 19, 433-442. [CrossRef] [PubMed]

12. Pichler, R.; Afkarian, M.; Dieter, B.P.; Tuttle, K.R. Immunity and inflammation in diabetic kidney disease: Translating mechanisms to biomarkers and treatment targets. Am. J. Physiol. Ren. Physiol. 2017, 312, F716-F731. [CrossRef] [PubMed]

13. Thomas, M.C.; Brownlee, M.; Susztak, K.; Sharma, K.; Jandeleit-Dahm, K.A.M.; Zoungas, S.; Rossing, P.; Groop, P.H.; Cooper, M.E. Diabetic kidney disease. Nat. Rev. Dis. Prim. 2015, 1, 1-20. [CrossRef] [PubMed] 
14. Berthier, C.C.; Zhang, H.; Schin, M.; Henger, A.; Nelson, R.G.; Yee, B.; Boucherot, A.; Neusser, M.A.; Cohen, C.D.; Carter-Su, C.; et al. Enhanced expression of janus kinase-signal transducer and activator of transcription pathway members in human diabetic nephropathy. Diabetes 2009, 58, 469-477. [CrossRef] [PubMed]

15. Starkey, J.M.; Haidacher, S.J.; LeJeune, W.S.; Zhang, X.; Tieu, B.C.; Choudhary, S.; Brasier, A.R.; Denner, L.A.; Tilton, R.G. Diabetes-induced activation of canonical and noncanonical nuclear factor- $\kappa \mathrm{B}$ pathways in renal cortex. Diabetes 2006, 55, 1252-1259. [CrossRef]

16. Rabelink, T.J.; De Zeeuw, D. The glycocalyx-Linking albuminuria with renal and cardiovascular disease. Nat. Rev. Nephrol. 2015, 11, 667-676. [CrossRef] [PubMed]

17. Agere, S.A.; Kim, E.Y.; Akhtar, N.; Ahmed, S. Syndecans in chronic inflammatory and autoimmune diseases: Pathological insights and therapeutic opportunities. J. Cell. Physiol. 2018, 233, 6346-6358. [CrossRef]

18. Moreno, J.A.; Moreno, S.; Rubio-Navarro, A.; Gómez-Guerrero, C.; Ortiz, A.; Egido, J. Role of chemokines in proteinuric kidney disorders. Expert Rev. Mol. Med. 2014, 16, e3. [CrossRef]

19. Langer, H.F.; Chavakis, T. Leukocyte-endothelial interactions in inflammation. J. Cell. Mol. Med. 2009, 13, 1211-1220. [CrossRef]

20. Luis-Rodríguez, D.; Martínez-Castelao, A.; Górriz, J.L.; De-Álvaro, F.; Navarro-González, J.F. Pathophysiological role and therapeutic implications of inflammation in diabetic nephropathy. World J. Diabetes 2012, 3, 7-18. [CrossRef]

21. Cachofeiro, V.; Goicochea, M.; De Vinuesa, S.G.; Oubĩa, P.; Lahera, V.; Lũo, J. Oxidative stress and inflammation, a link between chronic kidney disease and cardiovascular disease. Kidney Int. 2008, 74, S4-S9. [CrossRef]

22. Sagoo, M.K.; Gnudi, L. Diabetic nephropathy: Is there a role for oxidative stress? Free Radic. Biol. Med. 2018, 116, 50-63. [CrossRef]

23. Moreno, J.A.; Gomez-Guerrero, C.; Mas, S.; Sanz, A.B.; Lorenzo, O.; Ruiz-Ortega, M.; Opazo, L.; Mezzano, S.; Egido, J. Targeting inflammation in diabetic nephropathy: A tale of hope. Expert Opin. Investig. Drugs 2018, 27, 917-930. [CrossRef]

24. Elmarakby, A.A.; Sullivan, J.C. Relationship between oxidative stress and inflammatory cytokines in diabetic nephropathy. Cardiovasc. Ther. 2012, 30, 49-59. [CrossRef]

25. Kuhad, A.; Chopra, K. Attenuation of diabetic nephropathy by tocotrienol: Involvement of NFkB signaling pathway. Life Sci. 2009, 84, 296-301. [CrossRef]

26. Ebenezer, P.J.; Mariappan, N.; Elks, C.M.; Haque, M.; Francis, J. Diet-induced renal changes in zucker rats are ameliorated by the superoxide dismutase mimetic TEMPOL. Obesity 2009, 17, 1994-2002. [CrossRef] [PubMed]

27. Esposito, K.; Nappo, F.; Marfella, R.; Giugliano, G.; Giugliano, F.; Ciotola, M.; Quagliaro, L.; Ceriello, A.; Giugliano, D. Inflammatory cytokine concentrations are acutely increased by hyperglycemia in humans: Role of oxidative stress. Circulation 2002, 106, 2067-2072. [CrossRef]

28. Onozato, M.L.; Tojo, A.; Goto, A.; Fujita, T. Radical scavenging effect of gliclazide in diabetic rats fed with a high cholesterol diet. Kidney Int. 2004, 65, 951-960. [CrossRef] [PubMed]

29. Wang, L.; Zhang, L.; Yu, Y.; Wang, Y.; Niu, N. The protective effects of taurine against early renal injury in STZ-induced diabetic rats, correlated with inhibition of renal LOX-1-mediated ICAM-1 expression. Ren. Fail. 2008, 30, 763-771. [CrossRef]

30. Arnalich, F.; Hernanz, A.; Lopez-Maderuelo, D.; Pena, J.M.; Camacho, J.; Madero, R.; Vazquez, J.J.; Montiel, C. Enhanced acute-phase response and oxidative stress in older adults with type II diabetes. Horm. Metab. Res. 2000, 32, 407-412. [CrossRef] [PubMed]

31. Cipollone, F.; Chiarelli, F.; Iezzi, A.; Fazia, M.L.; Cuccurullo, C.; Pini, B.; De Cesare, D.; Torello, M.; Tumini, S.; Cuccurullo, F.; et al. Relationship between reduced BCL-2 expression in circulating mononuclear cells and early nephropathy in type 1 diabetes. Int. J. Immunopathol. Pharmacol. 2005, 18, 625-635. [CrossRef] [PubMed]

32. Chiarelli, F.; Cipollone, F.; Mohn, A.; Marini, M.; Iezzi, A.; Fazia, M.; Tumini, S.; De Cesare, D.; Pomilio, M.; Pierdomenico, S.D.; et al. Circulating monocyte chemoattractant protein-1 and early development of nephropathy in type 1 diabetes. Diabetes Care 2002, 25, 1829-1834. [CrossRef] [PubMed]

33. Schmid, H.; Boucherot, A.; Yasuda, Y.; Henger, A.; Brunner, B.; Eichinger, F.; Nitsche, A.; Kiss, E.; Bleich, M.; Gröne, H.J.; et al. Modular activation of nuclear factor- $\mathrm{kB}$ transcriptional programs in human diabetic nephropathy. Diabetes 2006, 55, 2993-3003. [CrossRef] [PubMed] 
34. García-García, P.M. Inflammation in diabetic kidney disease. World J. Diabetes 2014, 5, 431. [CrossRef]

35. Meyer, M.; Schreck, R.; Baeuerle, P.A. H2O2 and antioxidants have opposite effects on activation of NF-kappa $\mathrm{B}$ and AP-1 in intact cells: AP-1 as secondary antioxidant-responsive factor. EMBO J. 1993, 12, 2005-2015. [CrossRef]

36. Chow, F.; Ozols, E.; Nikolic-Paterson, D.J.; Atkins, R.C.; Tesch, G.H. Macrophages in mouse type 2 diabetic nephropathy: Correlation with diabetic state and progressive renal injury. Kidney Int. 2004, 65, 116-128. [CrossRef]

37. Nguyen, D.; Ping, F.; Mu, W.; Hill, P.; Atkins, R.C.; Chadban, S.J. Macrophage accumulation in human progressive diabetic nephropathy. Nephrology 2006, 11, 226-231. [CrossRef]

38. Chow, F.Y.; Nikolic-Paterson, D.J.; Ozols, E.; Atkins, R.C.; Rollin, B.J.; Tesch, G.H. Monocyte chemoattractant protein-1 promotes the development of diabetic renal injury in streptozotocin-treated mice. Kidney Int. 2006, 69, 73-80. [CrossRef]

39. Chow, F.Y.; Nikolic-Paterson, D.J.; Ma, F.Y.; Ozols, E.; Rollins, B.J.; Tesch, G.H. Monocyte chemoattractant protein-1-induced tissue inflammation is critical for the development of renal injury but not type 2 diabetes in obese $\mathrm{db} / \mathrm{db}$ mice. Diabetologia 2007, 50, 471-480. [CrossRef]

40. Okada, S.; Shikata, K.; Matsuda, M.; Ogawa, D.; Usui, H.; Kido, Y.; Nagase, R.; Wada, J.; Shikata, Y.; Makino, H. Intercellular adhesion molecule-1-deficient mice are resistant against renal injury after induction of diabetes. Diabetes 2003, 52, 2586-2593. [CrossRef]

41. You, H.; Gao, T.; Cooper, T.K.; Brian Reeves, W.; Awad, A.S. Macrophages directly mediate diabetic renal injury. Am. J. Physiol. Renal Physiol. 2013, 305, 1719-1727. [CrossRef] [PubMed]

42. Ikezumi, Y.; Hurst, L.A.; Masaki, T.; Atkins, R.C.; Nikolic-Paterson, D.J. Adoptive transfer studies demonstrate that macrophages can induce proteinuria and mesangial cell proliferation. Kidney Int. 2003, 63, 83-95. [CrossRef] [PubMed]

43. Pawluczyk, I.Z.; Harris, K.P. Macrophages Promote Prosclerotic Responses in Cultured Rat Mesangial Cells: A Mechanism for the Initiation of Glomerulosclerosis. J. Am. Soc. Nephrol. 1997, 8, 1525-1536. [PubMed]

44. Cui, X.; Kushiyama, A.; Yoneda, M.; Nakatsu, Y.; Guo, Y.; Zhang, J.; Ono, H.; Kanna, M.; Sakoda, H.; Ono, H.; et al. Macrophage foam cell formation is augmented in serum from patients with diabetic angiopathy. Diabetes Res. Clin. Pract. 2010, 87, 57-63. [CrossRef] [PubMed]

45. Sano, J.; Shirakura, S.; Oda, S.; Hara, T.; Ishihara, T. Foam cells generated by a combination of hyperglycemia and hyperlipemia in rats. Pathol. Int. 2004, 54, 904-913. [CrossRef] [PubMed]

46. Chen, R.; Fu, S.; Fan, X.; Lotze, M.T.; Zeh, H.J.; Tang, D. Nuclear DAMP complex-mediated RAGE-dependent macrophage cell death. Biochem. Biophys. Res. Commun. 2015, 458, 650-655. [CrossRef] [PubMed]

47. Kaplan, M.; Kerry, R.; Aviram, M.; Hayek, T. High glucose concentration increases macrophage cholesterol biosynthesis in diabetes through activation of the sterol regulatory element binding protein 1 (SREBP1): Inhibitory effect of insulin. J. Cardiovasc. Pharmacol. 2008, 52, 324-332. [CrossRef] [PubMed]

48. Zheng, Z.; Zheng, F. Immune Cells and Inflammation in Diabetic Nephropathy. J. Diabetes Res. 2016, 1841690. [CrossRef] [PubMed]

49. Wang, X.; Yao, B.; Wang, Y.; Fan, X.; Wang, S.; Niu, A.; Yang, H.; Fogo, A.; Zhang, M.-Z.; Harris, R.C. Macrophage Cyclooxygenase-2 Protects Against Development of Diabetic Nephropathy. Diabetes 2017, 66, 494-504. [CrossRef]

50. Ricardo, S.D.; van Goor, H.; Eddy, A.A. Macrophage diversity in renal injury and repair. J. Clin. Investig. 2008, 118, 3522-3530. [CrossRef]

51. Gobert, A.P.; Verriere, T.; Asim, M.; Barry, D.P.; Piazuelo, M.B.; Sablet, T.; Delgado, A.G.; Bravo, L.E.; Correa, P.; Peek, R.M., Jr.; et al. Heme oxygenase-1 dysregulates macrophage polarization and the immune response to Helicobacter pylori. J. Immunol. 2014, 193, 3013-3022. [CrossRef] [PubMed]

52. Rogers, N.M.; Ferenbach, D.A.; Isenberg, J.S.; Thomson, A.W.; Hughes, J. Dendritic cells and macrophages in the kidney: A spectrum of good and evil. Nat. Publ. Gr. 2014, 10, 625-643. [CrossRef] [PubMed]

53. Weisheit, C.K.; Engel, D.R.; Kurts, C. Dendritic cells and macrophages: Sentinels in the kidney. Clin. J. Am. Soc. Nephrol. 2015, 10, 1841-1851. [CrossRef] [PubMed]

54. Vu Manh, T.-P.; Bertho, N.; Hosmalin, A.; Schwartz-Cornil, I.; Dalod, M. Investigating Evolutionary Conservation of Dendritic Cell Subset Identity and Functions. Front. Immunol. 2015, 6, 260. [CrossRef] [PubMed] 
55. Zhang, F.; Wang, C.; Wen, X.; Chen, Y.; Mao, R.; Cui, D.; Li, L.; Liu, J.; Chen, Y.; Cheng, J.; et al. Mesenchymal stem cells alleviate rat diabetic nephropathy by suppressing CD103+ DCs-mediated CD8+ T cell responses. J. Cell. Mol. Med. 2020, 24, 5817-5831. [CrossRef]

56. Wang, R.; Chen, T.; Wang, C.; Zhang, Z.; Wang, X.M.; Li, Q.; Lee, V.W.S.; Wang, Y.M.; Zheng, G.; Alexander, S.I.; et al. Flt3 inhibition alleviates chronic kidney disease by suppressing CD103+ dendritic cell-mediated T cell activation. Nephrol. Dial. Transplant. 2018, 34, 1853-1863. [CrossRef] [PubMed]

57. Moon, J.-Y.; Jeong, K.-H.; Lee, T.-W.; Ihm, C.-G.; Lim, S.J.; Lee, S.-H. Aberrant recruitment and activation of T cells in diabetic nephropathy. Am. J. Nephrol. 2012, 35, 164-174. [CrossRef]

58. Peng, X.; Xiao, Z.; Zhang, J.; Li, Y.; Dong, Y.; Du, J. IL-17A produced by both $\gamma \delta \mathrm{T}$ and Th17 cells promotes renal fibrosis via RANTES-mediated leukocyte infiltration after renal obstruction. J. Pathol. 2015, 235, 79-89. [CrossRef]

59. Lim, A.K.H.; Ma, F.Y.; Nikolic-Paterson, D.J.; Kitching, A.R.; Thomas, M.C.; Tesch, G.H. Lymphocytes promote albuminuria, but not renal dysfunction or histological damage in a mouse model of diabetic renal injury. Diabetologia 2010, 53, 1772-1782. [CrossRef]

60. Herrera, M.; Soderberg, M.; Sabirsh, A.; Valastro, B.; Molne, J.; Santamaria, B.; Valverde, A.M.; Guionaud, S.; Heasman, S.; Bigley, A.; et al. Inhibition of T-cell activation by the CTLA4-Fc Abatacept is sufficient to ameliorate proteinuric kidney disease. Am. J. Physiol. Renal Physiol. 2017, 312, F748-F759. [CrossRef]

61. Kim, S.-M.; Lee, S.-H.; Lee, A.; Kim, D.-J.; Kim, Y.-G.; Kim, S.-Y.; Jeong, K.-H.; Lee, T.-W.; Ihm, C.-G.; Lim, S.-J.; et al. Targeting T helper 17 by mycophenolate mofetil attenuates diabetic nephropathy progression. Transl. Res. 2015, 166, 375-383. [CrossRef] [PubMed]

62. Eller, K.; Kirsch, A.; Wolf, A.M.; Sopper, S.; Tagwerker, A.; Stanzl, U.; Wolf, D.; Patsch, W.; Rosenkranz, A.R.; Eller, P. Potential role of regulatory $\mathrm{T}$ cells in reversing obesity-linked insulin resistance and diabetic nephropathy. Diabetes 2011, 60, 2954-2962. [CrossRef] [PubMed]

63. Lopes-Virella, M.F.; Carter, R.E.; Baker, N.L.; Lachin, J.; Virella, G. High levels of oxidized LDL in circulating immune complexes are associated with increased odds of developing abnormal albuminuria in Type 1 diabetes. Nephrol. Dial. Transplant. 2012, 27, 1416-1423. [CrossRef] [PubMed]

64. Lopes-Virella, M.F.; Hunt, K.J.; Baker, N.L.; Virella, G.; VADT Group of Investigators. High levels of AGE-LDL, and of IgG antibodies reacting with MDA-lysine epitopes expressed by oxLDL and MDA-LDL in circulating immune complexes predict macroalbuminuria in patients with type 2 diabetes. J. Diabetes Complications 2016, 30, 693-699. [CrossRef] [PubMed]

65. Bergtold, A.; Gavhane, A.; D'Agati, V.; Madaio, M.; Clynes, R. FcR-bearing myeloid cells are responsible for triggering murine lupus nephritis. J. Immunol. 2006, 177, 7287-7295. [CrossRef]

66. Ding, A.; Wright, S.D.; Nathan, C. Activation of mouse peritoneal macrophages by monoclonal antibodies to MAC-1 (complement receptor type 3). J. Exp. Med. 1987, 165, 733-749. [CrossRef]

67. Mise, K.; Hoshino, J.; Ueno, T.; Sumida, K.; Hiramatsu, R.; Hasegawa, E.; Yamanouchi, M.; Hayami, N.; Suwabe, T.; Sawa, N.; et al. Clinical implications of linear immunofluorescent staining for immunoglobulin $\mathrm{G}$ in patients with diabetic nephropathy. Diabetes Res. Clin. Pract. 2014, 106, 522-530. [CrossRef]

68. Lopez-Parra, V.; Mallavia, B.; Lopez-Franco, O.; Ortiz-Muñoz, G.; Oguiza, A.; Recio, C.; Blanco, J.; Nimmerjahn, F.; Egido, J.; Gomez-Guerrero, C. Fc $\gamma$ receptor deficiency attenuates diabetic nephropathy. J. Am. Soc. Nephrol. 2012, 23, 1518-1527. [CrossRef]

69. Okon, K.; Stachura, J. Increased mast cell density in renal interstitium is correlated with relative interstitial volume, serum creatinine and urea especially in diabetic nephropathy but also in primary glomerulonephritis. Pol. J. Pathol. 2007, 58, 193-197.

70. Zheng, J.M.; Yao, G.H.; Cheng, Z.; Wang, R.; Liu, Z.H. Pathogenic role of mast cells in the development of diabetic nephropathy: A study of patients at different stages of the disease. Diabetologia 2012, 55, 801-811. [CrossRef]

71. Yin, D.-D.; Luo, J.-H.; Zhao, Z.-Y.; Liao, Y.-J.; Li, Y. Tranilast prevents renal interstitial fibrosis by blocking mast cell infiltration in a rat model of diabetic kidney disease. Mol. Med. Rep. 2018, 17, 7356-7364. [CrossRef] [PubMed]

72. Bivona, B.J.; Takai, S.; Seth, D.M.; Satou, R.; Harrison-Bernard, L.M. Chymase inhibition retards albuminuria in type 2 diabetes. Physiol. Rep. 2019, 7, e14302. [CrossRef] 
73. Takahashi, T.; Hato, F.; Yamane, T.; Inaba, M.; Okuno, Y.; Nishizawa, Y.; Kitagawa, S. Increased spontaneous adherence of neutrophils from type 2 diabetic patients with overt proteinuria: Possible role of the progression of diabetic nephropathy. Diabetes Care 2000, 23, 417-418. [CrossRef] [PubMed]

74. Watanabe, A.; Tomino, Y.; Yokoyama, K.; Koide, H. Production of hydrogen peroxide by neutrophilic polymorphonuclear leukocytes in patients with diabetic nephropathy. J. Clin. Lab. Anal. 1993, 7, $209-213$. [CrossRef] [PubMed]

75. Ohmori, M.; Harada, K.; Kitoh, Y.; Nagasaka, S.I.; Saito, T.; Fujimura, A. The functions of circulatory polymorphonuclear leukocytes in diabetic patients with and without diabetic triopathy. Life Sci. 2000, 66, 1861-1870. [CrossRef]

76. Kawamoto, R.; Ninomiya, D.; Kikuchi, A.; Akase, T.; Kasai, Y.; Kusunoki, T.; Ohtsuka, N.; Kumagi, T. Association of neutrophil-to-lymphocyte ratio with early renal dysfunction and albuminuria among diabetic patients. Int. Urol. Nephrol. 2019, 51, 483-490. [CrossRef]

77. Shikata, K.; Makino, H. Microinflammation in the pathogenesis of diabetic nephropathy. J. Diabetes Investig. 2013, 4, 142-149. [CrossRef]

78. Sucosky, P.; Balachandran, K.; Elhammali, A.; Jo, H.; Yoganathan, A.P. Altered shear stress stimulates upregulation of endothelial VCAM-1 and ICAM-1 in a BMP-4- and TGF- $\beta 1$-dependent pathway. Arterioscler. Thromb. Vasc. Biol. 2009, 29, 254-260. [CrossRef]

79. Sumagin, R.; Sarelius, I.H. TNF- $\alpha$ activation of arterioles and venules alters distribution and levels of ICAM-1 and affects leukocyte-endothelial cell interactions. Am. J. Physiol. Hear. Circ. Physiol. 2006, 291, H2116-H2125. [CrossRef]

80. Coimbra, T.M.; Janssen, U.; Gröne, H.J.; Ostendorf, T.; Kunter, U.; Schmidt, H.; Brabant, G.; Floege, J. Early events leading to renal injury in obese Zucker (fatty) rats with type II diabetes. Kidney Int. 2000, 57, 167-182. [CrossRef]

81. Karimi, Z.; Kahe, F.; Jamil, A.; Marszalek, J.; Ghanbari, A.; Afarideh, M.; Khajeh, E.; Noshad, S.; Esteghamati, A.; Chi, G. Intercellular adhesion molecule-1 in diabetic patients with and without microalbuminuria. Diabetes Metab. Syndr. Clin. Res. Rev. 2018, 12, 365-368. [CrossRef] [PubMed]

82. Lin, J.; Glynn, R.J.; Rifai, N.; Manson, J.E.; Ridker, P.M.; Nathan, D.M.; Schaumberg, D.A. Inflammation and progressive nephropathy in type 1 diabetes in the diabetes control and complications trial. Diabetes Care 2008, 31, 2338-2343. [CrossRef] [PubMed]

83. Liu, L.; He, D.; Fang, L.; Yan, X. Association between E469K polymorphism in the ICAM1 gene and the risk of diabetic nephropathy: A meta-analysis. Lipids Health Dis. 2018, 17, 293. [CrossRef] [PubMed]

84. Sugimoto, H.; Shikata, K.; Hirata, K.; Akiyama, K.; Matsuda, M.; Kushiro, M.; Shikata, Y.; Miyatake, N.; Miyasaka, M.; Makino, H. Increased expression of intercellular adhesion molecule-1 (ICAM-1) in diabetic rat glomeruli: Glomerular hyperfiltration is a potential mechanism of ICAM-1 upregulation. Diabetes 1997, 46, 2075-2081. [CrossRef] [PubMed]

85. Rubio-Guerra, A.F.; Vargas-Robles, H.; Lozano Nuevo, J.J.; Escalante-Acosta, B.A. Correlation between circulating adhesion molecule levels and albuminuria in type-2 diabetic hypertensive patients. Kidney Blood Press. Res. 2009, 32, 106-109. [CrossRef] [PubMed]

86. Stehouwer, C.D.A.; Gall, M.-A.; Twisk, J.W.R.; Knudsen, E.; Emeis, J.J.; Parving, H.-H. Increased Urinary Albumin Excretion, Endothelial Dysfunction, and Chronic Low-Grade Inflammation in Type 2 Diabetes. Diabetes 2002, 51, 1157-1165. [CrossRef] [PubMed]

87. Salmi, M.; Jalkanen, S. Vascular adhesion protein-1: A cell surface amine oxidase in translation. Antioxidants Redox Signal. 2019, 30, 314-332. [CrossRef]

88. Li, H.Y.; Wei, J.N.; Lin, M.S.; Smith, D.J.; Vainio, J.; Lin, C.H.; Chiang, F.T.; Shih, S.R.; Huang, C.H.; Wu, M.Y.; et al. Serum vascular adhesion protein-1 is increased in acute and chronic hyperglycemia. Clin. Chim. Acta 2009, 404, 149-153. [CrossRef]

89. Li, H.Y.; Lin, H.A.; Nien, F.J.; Wu, V.C.; Jiang, Y.D.; Chang, T.J.; Kao, H.L.; Lin, M.S.; Wei, J.N.; Lin, C.H.; et al. Serum Vascular Adhesion Protein-1 Predicts End-Stage Renal Disease in Patients with Type 2 Diabetes. PLoS ONE 2016, 11, e0147981. [CrossRef]

90. Li, H.Y.; Jiang, Y.D.; Chang, T.J.; Wei, J.N.; Lin, M.S.; Lin, C.H.; Chiang, F.T.; Shih, S.R.; Hung, C.S.; Hua, C.H.; et al. Serum vascular adhesion protein-1 predicts 10-year cardiovascular and cancer mortality in individuals with type 2 diabetes. Diabetes 2011, 60, 993-999. [CrossRef] 
91. De Zeeuw, D.; Renfurm, R.W.; Bakris, G.; Rossing, P.; Perkovic, V.; Hou, F.F.; Nangaku, M.; Sharma, K.; Heerspink, H.J.L.; Garcia-Hernandez, A.; et al. Efficacy of a novel inhibitor of vascular adhesion protein-1 in reducing albuminuria in patients with diabetic kidney disease (ALBUM): A randomised, placebo-controlled, phase 2 trial. Lancet Diabetes Endocrinol. 2018, 6, 925-933. [CrossRef]

92. Pugliese, G.; Iacobini, C.; Pesce, C.M.; Menini, S. Galectin-3: An emerging all-out player in metabolic disorders and their complications. Glycobiology 2015, 25, 136-150. [CrossRef] [PubMed]

93. Drechsler, C.; Delgado, G.; Wanner, C.; Blouin, K.; Pilz, S.; Tomaschitz, A.; Kleber, M.E.; Dressel, A.; Willmes, C.; Krane, V.; et al. Galectin-3, renal function, and clinical outcomes: Results from the luric and 4D studies. J. Am. Soc. Nephrol. 2015, 26, 2213-2221. [CrossRef] [PubMed]

94. Pozzi, A.; Zent, R. Integrins in kidney disease. J. Am. Soc. Nephrol. 2013, 24, 1034-1039. [CrossRef] [PubMed]

95. Yoon, S.; Gingras, D.; Bendayan, M. Alterations of vitronectin and its receptor $\alpha \mathrm{v}$ integrin in the rat renal glomerular wall during diabetes. Am. J. Kidney Dis. 2001, 38, 1298-1306. [CrossRef] [PubMed]

96. Maile, L.A.; Busby, W.H.; Gollahon, K.A.; Flowers, W.; Garbacik, N.; Garbacik, S.; Stewart, K.; Nichols, T.; Bellinger, D.; Patel, A.; et al. Blocking ligand occupancy of the $\alpha \mathrm{V} \beta 3$ integrin inhibits the development of nephropathy in diabetic pigs. Endocrinology 2014, 155, 4665-4675. [CrossRef]

97. Zhou, X.; Zhang, J.; Haimbach, R.; Zhu, W.; Mayer-Ezell, R.; Garcia-Calvo, M.; Smith, E.; Price, O.; Kan, Y.; Zycband, E.; et al. An integrin antagonist (MK-0429) decreases proteinuria and renal fibrosis in the ZSF1 rat diabetic nephropathy model. Pharmacol. Res. Perspect. 2017, 5, e00354. [CrossRef]

98. Hirata, K.; Shikata, K.; Matsuda, M.; Akiyama, K.; Sugimoto, H.; Kushiro, M.; Makino, H. Increased expression of selectins in kidneys of patients with diabetic nephropathy. Diabetologia 1998, 41, 185-192. [CrossRef]

99. Narumi, S.; Onozato, M.L.; Tojo, A.; Sakamoto, S.; Tamatani, T. Tissue-specific induction of E-selectin in glomeruli is augmented following diabetes mellitus. Nephron 2001, 89, 161-171. [CrossRef]

100. Soedamah-Muthu, S.S.; Chaturvedi, N.; Schalkwijk, C.G.; Stehouwer, C.D.A.; Ebeling, P.; Fuller, J.H.; EURODIAB Prospective Complications Study Group. Soluble vascular cell adhesion molecule-1 and soluble E-selectin are associated with micro- and macrovascular complications in Type 1 diabetic patients. J. Diabetes Complications 2006, 20, 188-195. [CrossRef]

101. Wang, F.; Xing, T.; Wang, N.; Liu, L. Clinical significance of plasma CD146 and P-selectin in patients with type 2 diabetic nephropathy. Cytokine 2012, 57, 127-129. [CrossRef] [PubMed]

102. Utsumi, K.; Yasuda, F.; Watanabe, Y.; Higo, S.; Hirama, A.; Fujita, E.; Ueda, K.; Mii, A.; Kaneko, T.; Mishina, M.; et al. Effects of olmesartan and imidapril on the plasma adiponectin, P-selectin, and MDA-LDL levels of diabetic nephropathy patients. Clin. Chim. Acta 2012, 413, 348-349. [CrossRef] [PubMed]

103. Chung, A.C.K.; Lan, H.Y. Chemokines in renal injury. J. Am. Soc. Nephrol. 2011, 22, 802-809. [CrossRef] [PubMed]

104. Mezzano, S.; Aros, C.; Droguett, A.; Burgos, M.E.; Ardiles, L.; Flores, C.; Schneider, H.; Ruiz-Ortega, M.; Egido, J. NF-kappaB activation and overexpression of regulated genes in human diabetic nephropathy. Nephrol. Dial. Transplant. 2004, 19, 2505-2512. [CrossRef] [PubMed]

105. Ruster, C.; Wolf, G. The role of chemokines and chemokine receptors in diabetic nephropathy. Front. Biosci. 2008, 13, 944-955. [CrossRef]

106. Siddiqi, F.S.; Chen, L.-H.; Advani, S.L.; Thai, K.; Batchu, S.N.; Alghamdi, T.A.; White, K.E.; Sood, M.M.; Gibson, I.W.; Connelly, K.A.; et al. CXCR4 promotes renal tubular cell survival in male diabetic rats: Implications for ligand inactivation in the human kidney. Endocrinology 2015, 156, 1121-1132. [CrossRef]

107. Verhave, J.C.; Bouchard, J.; Goupil, R.; Pichette, V.; Brachemi, S.; Madore, F.; Troyanov, S. Clinical value of inflammatory urinary biomarkers in overt diabetic nephropathy: A prospective study. Diabetes Res. Clin. Pract. 2013, 101, 333-340. [CrossRef]

108. Higurashi, M.; Ohya, Y.; Joh, K.; Muraguchi, M.; Nishimura, M.; Terawaki, H.; Yagui, K.; Hashimoto, N.; Saito, Y.; Yamada, K. Increased urinary levels of CXCL5, CXCL8 and CXCL9 in patients with Type 2 diabetic nephropathy. J. Diabetes Complications 2009, 23, 178-184. [CrossRef]

109. Wang, G.; Lai, F.M.-M.; Chow, K.-M.; Kwan, B.C.-H.; Pang, W.-F.; Luk, C.C.-W.; Leung, C.-B.; Li, P.K.-T.; Szeto, C.-C. Urinary mRNA levels of ELR-negative CXC chemokine ligand and extracellular matrix in diabetic nephropathy. Diabetes Metab. Res. Rev. 2015, 31, 699-706. [CrossRef] 
110. Uematsu, M.; Nakamura, T.; Yoshizaki, T.; Watanabe, Y.; Deyama, J.; Watanabe, K.; Kobayashi, T.; Fujioka, D.; Saito, Y.; Nakamura, K.; et al. High levels of stromal cell-derived factor-1 $\alpha$ predict short-term progression of renal dysfunction in patients with coronary artery disease. Clin. Exp. Nephrol. 2019, 23, 920-927. [CrossRef]

111. Ihm, C.G.; Park, J.K.; Hong, S.P.; Lee, T.W.; Cho, B.S.; Kim, M.J.; Cha, D.R.; Ha, H. A high glucose concentration stimulates the expression of monocyte chemotactic peptide 1 in human mesangial cells. Nephron 1998, 79, 33-37. [CrossRef] [PubMed]

112. Zhuang, Q.; Cheng, K.; Ming, Y. CX3CL1/CX3CR1 Axis, as the Therapeutic Potential in Renal Diseases: Friend or Foe? Curr. Gene Ther. 2018, 17, 442-452. [CrossRef] [PubMed]

113. Kikuchi, Y.; Ikee, R.; Hemmi, N.; Hyodo, N.; Saigusa, T.; Namikoshi, T.; Yamada, M.; Suzuki, S.; Miura, S. Fractalkine and its receptor, CX3CR1, upregulation in streptozotocin-induced diabetic kidneys. Nephron. Exp. Nephrol. 2004, 97, e17-e25. [CrossRef] [PubMed]

114. Park, J.; Song, K.H.; Ha, H. Fractalkine increases mesangial cell proliferation through reactive oxygen species and mitogen-activated protein kinases. Transplant. Proc. 2012, 44, 1026-1028. [CrossRef] [PubMed]

115. Song, K.H.; Park, J.; Park, J.H.; Natarajan, R.; Ha, H. Fractalkine and its receptor mediate extracellular matrix accumulation in diabetic nephropathy in mice. Diabetologia 2013, 56, 1661-1669. [CrossRef] [PubMed]

116. Li, M.-X.; Zhao, Y.-F.; Qiao, H.-X.; Zhang, Y.-P.; Li, X.-J.; Ren, W.-D.; Yu, P. CXCR3 knockdown protects against high glucose-induced podocyte apoptosis and inflammatory cytokine production at the onset of diabetic nephropathy. Int. J. Clin. Exp. Pathol. 2017, 10, 8829-8838.

117. Wang, Y.; Wei, Q.; Liu, Q.; Li, Z.; Zhou, L.; Zou, F.; Yuan, Y.; Sun, Z. Crosstalk between monocytes and renal mesangial cells via interaction of metalloproteinases and fractalkine in diabetic nephropathy. Mol. Med. Rep. 2013, 8, 1817-1823. [CrossRef]

118. Gómez-Garre, D.; Largo, R.; Tejera, N.; Fortes, J.; Manzarbeitia, F.; Egido, J. Activation of NF-kappaB in tubular epithelial cells of rats with intense proteinuria: Role of angiotensin II and endothelin-1. Hypertension 2001, 37, 1171-1178. [CrossRef]

119. Sayyed, S.G.; Hägele, H.; Kulkarni, O.P.; Endlich, K.; Segerer, S.; Eulberg, D.; Klussmann, S.; Anders, H.-J. Podocytes produce homeostatic chemokine stromal cell-derived factor-1/CXCL12, which contributes to glomerulosclerosis, podocyte loss and albuminuria in a mouse model of type 2 diabetes. Diabetologia 2009, 52, 2445-2454. [CrossRef]

120. Zhang, Y.; Thai, K.; Kepecs, D.M.; Winer, D.; Gilbert, R.E. Reversing CXCL10 Deficiency Ameliorates Kidney Disease in Diabetic Mice. Am. J. Pathol. 2018, 188, 2763-2773. [CrossRef]

121. Kanamori, H.; Matsubara, T.; Mima, A.; Sumi, E.; Nagai, K.; Takahashi, T.; Abe, H.; Iehara, N.; Fukatsu, A.; Okamoto, H.; et al. Inhibition of MCP-1/CCR2 pathway ameliorates the development of diabetic nephropathy. Biochem. Biophys. Res. Commun. 2007, 360, 772-777. [CrossRef] [PubMed]

122. Lee, E.Y.; Chung, C.H.; Khoury, C.C.; Yeo, T.K.; Pyagay, P.E.; Wang, A.; Chen, S. The monocyte chemoattractant protein-1/CCR2 loop, inducible by TGF-beta, increases podocyte motility and albumin permeability. Am. J. Physiol. Renal Physiol. 2009, 297, F85-F94. [CrossRef]

123. Kang, Y.S.; Lee, M.H.; Song, H.K.; Ko, G.J.; Kwon, O.S.; Lim, T.K.; Kim, S.H.; Han, S.Y.; Han, K.H.; Lee, J.E.; et al. CCR2 antagonism improves insulin resistance, lipid metabolism, and diabetic nephropathy in type 2 diabetic mice. Kidney Int. 2010, 78, 883-894. [CrossRef] [PubMed]

124. Sullivan, T.; Miao, Z.; Dairaghi, D.J.; Krasinski, A.; Wang, Y.; Zhao, B.N.; Baumgart, T.; Ertl, L.S.; Pennell, A.; Seitz, L.; et al. CCR2 antagonist CCX140-B provides renal and glycemic benefits in diabetic transgenic human CCR2 knockin mice. Am. J. Physiol. Renal Physiol. 2013, 305, F1288-F1297. [CrossRef] [PubMed]

125. Darisipudi, M.N.; Kulkarni, O.P.; Sayyed, S.G.; Ryu, M.; Migliorini, A.; Sagrinati, C.; Parente, E.; Vater, A.; Eulberg, D.; Klussmann, S.; et al. Dual blockade of the homeostatic chemokine CXCL12 and the proinflammatory chemokine CCL2 has additive protective effects on diabetic kidney disease. Am. J. Pathol. 2011, 179, 116-124. [CrossRef] [PubMed]

126. de Zeeuw, D.; Bekker, P.; Henkel, E.; Hasslacher, C.; Gouni-Berthold, I.; Mehling, H.; Potarca, A.; Tesar, V.; Heerspink, H.J.L.; Schall, T.J.; et al. The effect of CCR2 inhibitor CCX140-B on residual albuminuria in patients with type 2 diabetes and nephropathy: A randomised trial. Lancet Diabetes Endocrinol. 2015, 3, 687-696. [CrossRef]

127. Menne, J.; Eulberg, D.; Beyer, D.; Baumann, M.; Saudek, F.; Valkusz, Z.; Więcek, A.; Haller, H.; Emapticap Study Group. C-C motif-ligand 2 inhibition with emapticap pegol (NOX-E36) in type 2 diabetic patients with albuminuria. Nephrol. Dial. Transplant. 2017, 32, 307-315. 
128. Gale, J.D.; Gilbert, S.; Blumenthal, S.; Elliott, T.; Pergola, P.E.; Goteti, K.; Scheele, W.; Perros-Huguet, C. Effect of PF-04634817, an Oral CCR2/5 Chemokine Receptor Antagonist, on Albuminuria in Adults with Overt Diabetic Nephropathy. Kidney Int. Rep. 2018, 3, 1316-1327. [CrossRef]

129. Moriwaki, Y.; Inokuchi, T.; Yamamoto, A.; Ka, T.; Tsutsumi, Z.; Takahashi, S.; Yamamoto, T. Effect of TNF-alpha inhibition on urinary albumin excretion in experimental diabetic rats. Acta Diabetol. 2007, 44, 215-218. [CrossRef]

130. Omote, K.; Gohda, T.; Murakoshi, M.; Sasaki, Y.; Kazuno, S.; Fujimura, T.; Ishizaka, M.; Sonoda, Y.; Tomino, Y. Role of the TNF pathway in the progression of diabetic nephropathy in KK-A(y) mice. Am. J. Physiol. Renal Physiol. 2014, 306, F1335-F1347. [CrossRef]

131. Abdelrahman, A.M.; Al Suleimani, Y.; Shalaby, A.; Ashique, M.; Manoj, P.; Ali, B.H. Effect of tocilizumab, an interleukin-6 inhibitor, on early stage streptozotocin-induced diabetic nephropathy in rats. Naunyn. Schmiedebergs. Arch. Pharmacol. 2019, 392, 1005-1013. [CrossRef]

132. Lei, Y.; Devarapu, S.K.; Motrapu, M.; Cohen, C.D.; Lindenmeyer, M.T.; Moll, S.; Kumar, S.V.; Anders, H.-J. Interleukin-1 $\beta$ Inhibition for Chronic Kidney Disease in Obese Mice With Type 2 Diabetes. Front. Immunol. 2019, 10, 1223. [CrossRef] [PubMed]

133. Mohamed, R.; Jayakumar, C.; Chen, F.; Fulton, D.; Stepp, D.; Gansevoort, R.T.; Ramesh, G. Low-Dose IL-17 Therapy Prevents and Reverses Diabetic Nephropathy, Metabolic Syndrome, and Associated Organ Fibrosis. J. Am. Soc. Nephrol. 2016, 27, 745-765. [CrossRef] [PubMed]

134. Lavoz, C.; Matus, Y.S.; Orejudo, M.; Carpio, J.D.; Droguett, A.; Egido, J.; Mezzano, S.; Ruiz-Ortega, M. Interleukin-17A blockade reduces albuminuria and kidney injury in an accelerated model of diabetic nephropathy. Kidney Int. 2019, 95, 1418-1432. [CrossRef] [PubMed]

135. Hsu, Y.H.; Li, H.H.; Sung, J.M.; Chen, W.Y.; Hou, Y.C.; Weng, Y.H.; Lai, W.T.; Wu, C.H.; Chang, M.S. Interleukin-20 targets podocytes and is upregulated in experimental murine diabetic nephropathy. Exp. Mol. Med. 2017, 49, e310. [CrossRef]

136. Wang, Z.; Wei, M.; Wang, M.; Chen, L.; Liu, H.; Ren, Y.; Shi, K.; Jiang, H. Inhibition of Macrophage Migration Inhibitory Factor Reduces Diabetic Nephropathy in Type II Diabetes Mice. Inflammation 2014, 37, 2020-2029. [CrossRef] [PubMed]

137. Khalilpour, J.; Roshan-Milani, S.; Gharalari, F.H.; Fard, A.A. Macrophage migration inhibitory factor antagonist (p425) ameliorates kidney histopathological and functional changes in diabetic rats. J. Bras. Nefrol. 2019, 41, 315-322. [CrossRef]

138. Navarro, J.F.; Mora-Fernández, C. The role of TNF- $\alpha$ in diabetic nephropathy: Pathogenic and therapeutic implications. Cytokine Growth Factor Rev. 2006, 17, 441-450. [CrossRef]

139. Navarro, J.F.; Milena, F.J.; Mora, C.; León, C.; Claverie, F.; Flores, C.; García, J. Tumor necrosis factor-alpha gene expression in diabetic nephropathy: Relationship with urinary albumin excretion and effect of angiotensin-converting enzyme inhibition. Kidney Int. Suppl. 2005, 68, S98-S102. [CrossRef]

140. Niewczas, M.A.; Gohda, T.; Skupien, J.; Smiles, A.M.; Walker, W.H.; Rosetti, F.; Cullere, X.; Eckfeldt, J.H.; Doria, A.; Mayadas, T.N.; et al. Circulating TNF receptors 1 and 2 predict ESRD in type 2 diabetes. J. Am. Soc. Nephrol. 2012, 23, 507-515. [CrossRef]

141. Navarro, J.F.; Mora, C.; Rivero, A.; Gallego, E.; Chahin, J.; Macia, M.; Mendez, M.L.; Garcia, J. Urinary protein excretion and serum tumor necrosis factor in diabetic patients with advanced renal failure: Effects of pentoxifylline administration. Am. J. Kidney Dis. 1999, 33, 458-463. [CrossRef]

142. Moriwaki, Y.; Yamamoto, T.; Shibutani, Y.; Aoki, E.; Tsutsumi, Z.; Takahashi, S.; Okamura, H.; Koga, M.; Fukuchi, M.; Hada, T. Elevated levels of interleukin-18 and tumor necrosis factor- $\alpha$ in serum of patients with type 2 diabetes mellitus: Relationship with diabetic nephropathy. Metabolism 2003, 52, 605-608. [CrossRef] [PubMed]

143. Gohda, T.; Tomino, Y. Novel biomarkers for the progression of diabetic nephropathy: Soluble TNF receptors. Curr. Diab. Rep. 2013, 13, 560-566. [CrossRef] [PubMed]

144. Gohda, T.; Maruyama, S.; Kamei, N.; Yamaguchi, S.; Shibata, T.; Murakoshi, M.; Horikoshi, S.; Tomino, Y.; Ohsawa, I.; Gotoh, H.; et al. Circulating TNF Receptors 1 and 2 Predict Mortality in Patients with End-stage Renal Disease Undergoing Dialysis. Sci. Rep. 2017, 7, 43520. [CrossRef]

145. DiPetrillo, K.; Gesek, F.A. Pentoxifylline ameliorates renal tumor necrosis factor expression, sodium retention, and renal hypertrophy in diabetic rats. Am. J. Nephrol. 2004, 24, 352-359. [CrossRef] 
146. Navarro-González, J.F.; Mora-Fernández, C.; Muros De Fuentes, M.; Chahin, J.; Méndez, M.L.; Gallego, E.; Macía, M.; Del Castillo, N.; Rivero, A.; Getino, M.A.; et al. Effect of pentoxifylline on renal function and urinary albumin excretion in patients with diabetic kidney disease: The PREDIAN trial. J. Am. Soc. Nephrol. 2015, 26, 220-229. [CrossRef]

147. DiPetrillo, K.; Coutermarsh, B.; Gesek, F.A. Urinary tumor necrosis factor contributes to sodium retention and renal hypertrophy during diabetes. Am. J. Physiol. Ren. Physiol. 2003, 284, F113-F121. [CrossRef]

148. Chen, B.; Wu, M.; Zang, C.; Li, Y.; Xu, Z. Association Between IL-6 Polymorphisms and Diabetic Nephropathy Risk: A Meta-analysis. Am. J. Med. Sci. 2019, 358, 363-373. [CrossRef]

149. Cui, Z.-H.; Lu, X.-T.; Xiao, K.-L.; Chen, Y.; Li, H.-Q. Association of Interleukin-6-174G/C Polymorphism with the Risk of Diabetic Nephropathy in Type 2 Diabetes: A Meta-analysis. Curr. Med. Sci. 2019, 39, 250-258. [CrossRef]

150. Wolkow, P.P.; Niewczas, M.A.; Perkins, B.; Ficociello, L.H.; Lipinski, B.; Warram, J.H.; Krolewski, A.S. Association of urinary inflammatory markers and renal decline in microalbuminuric type 1 diabetics. J. Am. Soc. Nephrol. 2008, 19, 789-797. [CrossRef]

151. Garbers, C.; Heink, S.; Korn, T.; Rose-John, S. Interleukin-6: Designing specific therapeutics for a complex cytokine. Nat. Rev. Drug Discov. 2018, 17, 395-412. [CrossRef]

152. Al-Mutairi, N.; Shabaan, D. Effects of tumor necrosis factor $\alpha$ inhibitors extend beyond psoriasis: Insulin sensitivity in psoriasis patients with type 2 diabetes mellitus. Cutis 2016, 97, 235-241. [PubMed]

153. Otsuka, Y.; Kiyohara, C.; Kashiwado, Y.; Sawabe, T.; Nagano, S.; Kimoto, Y.; Ayano, M.; Mitoma, H.; Akahoshi, M.; Arinobu, Y.; et al. Effects of tumor necrosis factor inhibitors and tocilizumab on the glycosylated hemoglobin levels in patients with rheumatoid arthritis; an observational study. PLoS ONE 2018, 13, e0196368. [CrossRef] [PubMed]

154. Buraczynska, M.; Ksiazek, K.; Wacinski, P.; Zaluska, W. Interleukin-1ß Gene (IL1B) Polymorphism and Risk of Developing Diabetic Nephropathy. Immunol. Investig. 2019, 48, 577-584. [CrossRef] [PubMed]

155. Herder, C.; Dalmas, E.; Böni-Schnetzler, M.; Donath, M.Y. The IL-1 Pathway in Type 2 Diabetes and Cardiovascular Complications. Trends Endocrinol. Metab. 2015, 26, 551-563. [CrossRef] [PubMed]

156. Stahel, M.; Becker, M.; Graf, N.; Michels, S. Systemic interleukin $1 \beta$ inhibition in proliferative diabetic retinopathy: A Prospective Open-Label Study Using Canakinumab. Retina 2016, 36, 385-391. [CrossRef]

157. Sims, J.E.; Smith, D.E. The IL-1 family: Regulators of immunity. Nat. Rev. Immunol. 2010, 10, 89-102. [CrossRef]

158. Lemos, D.R.; McMurdo, M.; Karaca, G.; Wilflingseder, J.; Leaf, I.A.; Gupta, N.; Miyoshi, T.; Susa, K.; Johnson, B.G.; Soliman, K.; et al. Interleukin-1 $\beta$ Activates a MYC-Dependent Metabolic Switch in Kidney Stromal Cells Necessary for Progressive Tubulointerstitial Fibrosis. J. Am. Soc. Nephrol. 2018, 29, 1690-1705. [CrossRef]

159. Vila, E.; Salaices, M. Cytokines and vascular reactivity in resistance arteries. Am. J. Physiol. Heart Circ. Physiol. 2005, 288, 1016-1021. [CrossRef]

160. Vallejo, S.; Palacios, E.; Romacho, T.; Villalobos, L.; Peiró, C.; Sánchez-Ferrer, C.F. The interleukin-1 receptor antagonist anakinra improves endothelial dysfunction in streptozotocin-induced diabetic rats. Cardiovasc. Diabetol. 2014, 13, 158. [CrossRef]

161. Everett, B.M.; Donath, M.Y.; Pradhan, A.D.; Thuren, T.; Pais, P.; Nicolau, J.C.; Glynn, R.J.; Libby, P.; Ridker, P.M. Anti-Inflammatory Therapy With Canakinumab for the Prevention and Management of Diabetes. J. Am. Coll. Cardiol. 2018, 71, 2392-2401. [CrossRef] [PubMed]

162. Ridker, P.M.; Everett, B.M.; Thuren, T.; MacFadyen, J.G.; Chang, W.H.; Ballantyne, C.; Fonseca, F.; Nicolau, J.; Koenig, W.; Anker, S.D.; et al. Antiinflammatory therapy with canakinumab for atherosclerotic disease. N. Engl. J. Med. 2017, 377, 1119-1131. [CrossRef] [PubMed]

163. Cavelti-Weder, C.; Babians-Brunner, A.; Keller, C.; Stahel, M.A.; Kurz-Levin, M.; Zayed, H.; Solinger, A.M.; Mandrup-Poulsen, T.; Dinarello, C.A.; Donath, M.Y. Effects of gevokizumab on glycemia and inflammatory markers in type 2 diabetes. Diabetes Care 2012, 35, 1654-1662. [CrossRef]

164. Larsen, C.M.; Faulenbach, M.; Vaag, A.; Vølund, A.; Ehses, J.A.; Seifert, B.; Mandrup-Poulsen, T.; Donath, M.Y. Interleukin-1-receptor antagonist in type 2 diabetes mellitus. N. Engl. J. Med. 2007, 356, 1517-1526. [CrossRef] [PubMed] 
165. Nowak, K.L.; Chonchol, M.; Ikizler, T.A.; Farmer-Bailey, H.; Salas, N.; Chaudhry, R.; Wang, W.; Smits, G.; Tengesdal, I.; Dinarello, C.A.; et al. IL-1 inhibition and vascular function in CKD. J. Am. Soc. Nephrol. 2017, 28, 971-980. [CrossRef] [PubMed]

166. White, P.C.; Adhikari, S.; Grishman, E.K.; Sumpter, K.M. A phase I study of anti-inflammatory therapy with rilonacept in adolescents and adults with type 1 diabetes mellitus. Pediatr. Diabetes 2018, 19, 788-793. [CrossRef]

167. Yaribeygi, H.; Atkin, S.L.; Sahebkar, A. Interleukin-18 and diabetic nephropathy: A review. J. Cell. Physiol. 2019, 234, 5674-5682. [CrossRef]

168. Park, C.C.; Morel, J.C.M.; Amin, M.A.; Connors, M.A.; Harlow, L.A.; Koch, A.E. Evidence of IL-18 as a Novel Angiogenic Mediator. J. Immunol. 2001, 167, 1644-1653. [CrossRef]

169. Yaribeygi, H.; Mohammadi, M.T.; Rezaee, R.; Sahebkar, A. Crocin improves renal function by declining Nox-4, IL-18, and p53 expression levels in an experimental model of diabetic nephropathy. J. Cell. Biochem. 2018, 119, 6080-6093. [CrossRef]

170. Miyauchi, K.; Takiyama, Y.; Honjyo, J.; Tateno, M.; Haneda, M. Upregulated IL-18 expression in type 2 diabetic subjects with nephropathy: TGF-beta1 enhanced IL-18 expression in human renal proximal tubular epithelial cells. Diabetes Res. Clin. Pract. 2009, 83, 190-199. [CrossRef]

171. Weisberg, S.P.; McCann, D.; Desai, M.; Rosenbaum, M.; Leibel, R.L.; Ferrante, A.W. Obesity is associated with macrophage accumulation in adipose tissue. J. Clin. Investig. 2003, 112, 1796-1808. [CrossRef] [PubMed]

172. Evans, J.; Collins, M.; Jennings, C.; van der Merwe, L.; Söderström, I.; Olsson, T.; Levitt, N.S.; Lambert, E.V.; Goedecke, J.H. The association of interleukin-18 genotype and serum levels with metabolic risk factors for cardiovascular disease. Eur. J. Endocrinol. 2007, 157, 633-640. [CrossRef] [PubMed]

173. Fujita, T.; Ogihara, N.; Kamura, Y.; Satomura, A.; Fuke, Y.; Shimizu, C.; Wada, Y.; Matsumoto, K. Interleukin-18 contributes more closely to the progression of diabetic nephropathy than other diabetic complications. Acta Diabetol. 2012, 49, 111-117. [CrossRef] [PubMed]

174. Nakamura, A.; Shikata, K.; Hiramatsu, M.; Nakatou, T.; Kitamura, T.; Wada, J.; Itoshima, T.; Makino, H. Serum interleukin-18 levels are associated with nephropathy and atherosclerosis in Japanese patients with type 2 diabetes. Diabetes Care 2005, 28, 2890-2895. [CrossRef]

175. Sueud, T.; Hadi, N.R.; Abdulameer, R.; Jamil, D.A.; Al-Aubaidy, H.A. Assessing urinary levels of IL-18, NGAL and albumin creatinine ratio in patients with diabetic nephropathy. Diabetes Metab. Syndr. 2019, 13, 564-568. [CrossRef]

176. McKie, E.A.; Reid, J.L.; Mistry, P.C.; DeWall, S.L.; Abberley, L.; Ambery, P.D.; Gil-Extremera, B. A Study to Investigate the Efficacy and Safety of an Anti-Interleukin-18 Monoclonal Antibody in the Treatment of Type 2 Diabetes Mellitus. PLoS ONE 2016, 11, e0150018. [CrossRef]

177. Mistry, P.; Reid, J.; Pouliquen, I.; McHugh, S.; Abberley, L.; DeWall, S.; Taylor, A.; Tong, X.; Del Cura, M.R.; McKie, E. Safety, tolerability, pharmacokinetics, and pharmacodynamics of single-dose anti-interleukin-18 mAb GSK1070806 in healthy and obese subjects. Int. J. Clin. Pharmacol. Ther. 2014, 52, 867-879. [CrossRef]

178. Cortvrindt, C.; Speeckaert, R.; Moerman, A.; Delanghe, J.R.; Speeckaert, M.M. The role of interleukin-17A in the pathogenesis of kidney diseases. Pathology 2017, 49, 247-258. [CrossRef]

179. Biswas, P.S. IL-17 in Renal Immunity and Autoimmunity. J. Immunol. 2018, 201, 3153-3159. [CrossRef]

180. Robert, M.; Miossec, P. Effects of Interleukin 17 on the cardiovascular system. Autoimmun. Rev. 2017, 16, 984-991. [CrossRef]

181. Ryba-Stanisławowska, M.; Skrzypkowska, M.; Myśliwiec, M.; Myśliwska, J. Loss of the balance between CD4(+)Foxp3(+) regulatory T cells and CD4(+)IL17A(+) Th17 cells in patients with type 1 diabetes. Hum. Immunol. 2013, 74, 701-707. [CrossRef] [PubMed]

182. Li, C.-R.; Mueller, E.E.; Bradley, L.M. Islet antigen-specific Th17 cells can induce TNF- $\alpha$-dependent autoimmune diabetes. J. Immunol. 2014, 192, 1425-1432. [CrossRef] [PubMed]

183. Baharlou, R.; Ahmadi-Vasmehjani, A.; Davami, M.H.; Faraji, F.; Atashzar, M.R.; Karimipour, F.; Sadeghi, A.; Asadi, M.-A.; Khoubyari, M. Elevated Levels of T-helper 17-associated Cytokines in Diabetes Type I Patients: Indicators for Following the Course of Disease. Immunol. Investig. 2016, 45, 641-651. [CrossRef] [PubMed]

184. Marwaha, A.K.; Panagiotopoulos, C.; Biggs, C.M.; Staiger, S.; Del Bel, K.L.; Hirschfeld, A.F.; Priatel, J.J.; Turvey, S.E.; Tan, R. Pre-diagnostic genotyping identifies T1D subjects with impaired Treg IL-2 signaling and an elevated proportion of FOXP3+IL-17+ cells. Genes Immun. 2017, 18, 15-21. [CrossRef] [PubMed] 
185. Galvan, D.L.; Danesh, F.R. Paradoxical role of IL-17 in progression of diabetic nephropathy. J. Am. Soc. Nephrol. 2016, 27, 657-658. [CrossRef]

186. Orejudo, M.; Rodrigues-Diez, R.R.; Rodrigues-Diez, R.; Garcia-Redondo, A.; Santos-Sánchez, L.; Rández-Garbayo, J.; Cannata-Ortiz, P.; Ramos, A.M.; Ortiz, A.; Selgas, R.; et al. Interleukin 17A Participates in Renal Inflammation Associated to Experimental and Human Hypertension. Front. Pharmacol. 2019, 10, 1015. [CrossRef]

187. Yao, W.; Sun, Y.; Wang, X.; Niu, K. Elevated Serum Level of Interleukin 17 in a Population With Prehypertension. J. Clin. Hypertens. (Greenwich) 2015, 17, 770-774. [CrossRef]

188. Baeten, D.; Sieper, J.; Braun, J.; Baraliakos, X.; Dougados, M.; Emery, P.; Deodhar, A.; Porter, B.; Martin, R.; Andersson, M.; et al. Secukinumab, an Interleukin-17A Inhibitor, in Ankylosing Spondylitis. N. Engl. J. Med. 2015, 373, 2534-2548. [CrossRef]

189. Leonardi, C.; Matheson, R.; Zachariae, C.; Cameron, G.; Li, L.; Edson-Heredia, E.; Braun, D.; Banerjee, S. Anti-Interleukin-17 Monoclonal Antibody Ixekizumab in Chronic Plaque Psoriasis. N. Engl. J. Med. 2012, 366, 1190-1199. [CrossRef]

190. Mease, P.; van der Heijde, D.; Landewé, R.; Mpofu, S.; Rahman, P.; Tahir, H.; Singhal, A.; Boettcher, E.; Navarra, S.; Meiser, K.; et al. Secukinumab improves active psoriatic arthritis symptoms and inhibits radiographic progression: Primary results from the randomised, double-blind, phase III FUTURE 5 study. Ann. Rheum. Dis. 2018, 77, 890-897. [CrossRef]

191. Vasanthakumar, R.; Mohan, V.; Anand, G.; Deepa, M.; Babu, S.; Aravindhan, V. Serum IL-9, IL-17, and TGF- $\beta$ levels in subjects with diabetic kidney disease (CURES-134). Cytokine 2015, 72, 109-112. [CrossRef] [PubMed]

192. Hetta, H.F.; Elkady, A.; Morsy, K.H.; Mohamed, I.S.; Ibrahim, M.A. Serum Level of IL17a among Cirrhotic Hepatitis C Virus Infected Patients with Incidence of Diabetes Mellitus. Egypt. J. Immunol. 2017, 24, 79-88. [PubMed]

193. Liu, S.-Y.; Chen, J.; Li, Y.-F. Clinical significance of serum interleukin-8 and soluble tumor necrosis factor-like weak inducer of apoptosis levels in patients with diabetic nephropathy. J. Diabetes Investig. 2018, 9, 1182-1188. [CrossRef] [PubMed]

194. Chen, L.; Liu, X.; Pan, Z.; Liu, S.; Han, H.; Zhao, C.; Tang, X. The role of IL-8/CXCR2 signaling in microcystin-LR triggered endothelial cell activation and increased vascular permeability. Chemosphere 2018, 194, 43-48. [CrossRef] [PubMed]

195. Yahya, M.J.; Ismail, P.; Nordin, N.; Md Akim, A.; Md. Yusuf, W.S.; Adam, N.L.; Yusoff, M.J. Association of CCL2, CCR5, ELMO1, and IL8 Polymorphism with Diabetic Nephropathy in Malaysian Type 2 Diabetic Patients. Int. J. Chronic Dis. 2019, 2019, 2053015.

196. Shen, Z.; Chen, Q.; Ying, H.; Ma, Z.; Bi, X.; Li, X.; Wang, M.; Jin, C.; Lai, D.; Zhao, Y.; et al. Identification of differentially expressed genes in the endothelial precursor cells of patients with type 2 diabetes mellitus by bioinformatics analysis. Exp. Ther. Med. 2019, 19, 499-510. [CrossRef]

197. Sharif, M.N.; Campanholle, G.; Nagiec, E.E.; Wang, J.; Syed, J.; O’Neil, S.P.; Zhan, Y.; Brenneman, K.; Homer, B.; Neubert, H.; et al. Soluble Fn14 Is Detected and Elevated in Mouse and Human Kidney Disease. PLoS ONE 2016, 11, e0155368. [CrossRef]

198. Umapathy, D.; Dornadula, S.; Krishnamoorthy, E.; Mariappanadar, V.; Viswanathan, V.; Ramkumar, K.M. YKL-40: A biomarker for early nephropathy in type 2 diabetic patients and its association with inflammatory cytokines. Immunobiology 2018, 223, 718-727. [CrossRef]

199. Yilmaz, M.I.; Carrero, J.J.; Martín-Ventura, J.L.; Sonmez, A.; Saglam, M.; Celik, T.; Yaman, H.; Yenicesu, M.; Eyileten, T.; Moreno, J.A.; et al. Combined therapy with renin-angiotensin system and calcium channel blockers in type 2 diabetic hypertensive patients with proteinuria: Effects on soluble TWEAK, PTX3, and flow-mediated dilation. Clin. J. Am. Soc. Nephrol. 2010, 5, 1174-1181. [CrossRef]

200. Mayer, C.; Bergholdt, R.; Cucak, H.; Rolin, B.C.; Sams, A.; Rosendahl, A. Neutralizing anti-il20 antibody treatment significantly modulates low grade inflammation without affecting $\mathrm{HbA} 1 \mathrm{c}$ in Type 2 diabetic db/db mice. PLoS ONE 2015, 10, e0131306. [CrossRef]

201. Blumberg, H.; Conklin, D.; Xu, W.F.; Grossmann, A.; Brender, T.; Carollo, S.; Eagan, M.; Foster, D.; Haldeman, B.A.; Hammond, A.; et al. Interleukin 20: Discovery, receptor identification, and role in epidermal function. Cell 2001, 104, 9-19. [CrossRef]

202. Mezzano, S.; Droguett, A.; Lavoz, C.; Krall, P.; Egido, J.; Ruiz-Ortega, M. Gremlin and renal diseases: Ready to jump the fence to clinical utility? Nephrol. Dial. Transplant. 2018, 33, 735-741. [CrossRef] 
203. Roxburgh, S.A.; Kattla, J.J.; Curran, S.P.; O'Meara, Y.M.; Pollock, C.A.; Goldschmeding, R.; Godson, C.; Martin, F.; Brazil, D.P. Allelic depletion of grem1 attenuates diabetic kidney disease. Diabetes 2009, 58, 1641-1650. [CrossRef]

204. Marchant, V.; Droguett, A.; Valderrama, G.; Eugenia Burgos, M.; Carpio, D.; Kerr, B.; Ruiz-Ortega, M.; Egido, J.; Mezzano, S. Tubular overexpression of gremlin in transgenic mice aggravates renal damage in diabetic nephropathy. Am. J. Physiol. Ren. Physiol. 2015, 309, F559-F568. [CrossRef]

205. Dolan, V.; Murphy, M.; Sadlier, D.; Lappin, D.; Doran, P.; Godson, C.; Martin, F.; O’Meara, Y.; Schmid, H.; Henger, A.; et al. Expression of gremlin, a bone morphogenetic protein antagonist, in human diabetic nephropathy. Am. J. Kidney Dis. 2005, 45, 1034-1039. [CrossRef]

206. Marquez-Exposito, L.; Lavoz, C.; Rodrigues-Diez, R.R.; Rayego-Mateos, S.; Orejudo, M.; Cantero-Navarro, E.; Ortiz, A.; Egido, J.; Selgas, R.; Mezzano, S.; et al. Gremlin regulates tubular epithelial to mesenchymal transition via VEGFR2: Potential role in renal fibrosis. Front. Pharmacol. 2018, 9, 1195. [CrossRef]

207. Lavoz, C.; Alique, M.; Rodrigues-Diez, R.; Pato, J.; Keri, G.; Mezzano, S.; Egido, J.; Ruiz-Ortega, M. Gremlin regulates renal inflammation via the vascular endothelial growth factor receptor 2 pathway. J. Pathol. 2015, 236, 407-420. [CrossRef]

208. Lavoz, C.; Rodrigues-Diez, R.R.; Plaza, A.; Carpio, D.; Egido, J.; Ruiz-Ortega, M.; Mezzano, S. VEGFR2 Blockade Improves Renal Damage in an Experimental Model of Type 2 Diabetic Nephropathy. J. Clin. Med. 2020, 9, 302. [CrossRef]

209. Sánchez-Zamora, Y.I.; Rodriguez-Sosa, M. The Role of MIF in Type 1 and Type 2 Diabetes Mellitus. J. Diabetes Res. 2014, 2014, 804519. [CrossRef]

210. Herder, C.; Kolb, H.; Koenig, W.; Haastert, B.; Müller-Scholze, S.; Rathmann, W.; Holle, R.; Thorand, B.; Wichmann, H.E. Association of systemic concentrations of macrophage migration inhibitory factor with impaired glucose tolerance and type 2 diabetes: Results from the Cooperative Health Research in the Region of Augsburg, Survey 4 (KORA S4). Diabetes Care 2006, 29, 368-371. [CrossRef]

211. Sanchez-Niño, M.D.; Sanz, A.B.; Ihalmo, P.; Lassila, M.; Holthofer, H.; Mezzano, S.; Aros, C.; Groop, P.H.; Saleem, M.A.; Mathieson, P.W.; et al. The MIF receptor CD74 in diabetic podocyte injury. J. Am. Soc. Nephrol. 2009, 20, 353-362. [CrossRef]

212. Perlman, A.S.; Chevalier, J.M.; Wilkinson, P.; Liu, H.; Parker, T.; Levine, D.M.; Sloan, B.J.; Gong, A.; Sherman, R.; Farrell, F.X. Serum inflammatory and immune mediators are elevated in early stage diabetic nephropathy. Ann. Clin. Lab. Sci. 2015, 45, 256-263.

213. Liu, J.; Zhao, Z.; Willcox, M.D.P.; Xu, B.; Shi, B. Multiplex bead analysis of urinary cytokines of type 2 diabetic patients with normo- and microalbuminuria. J. Immunoass. Immunochem. 2010, 31, 279-289. [CrossRef]

214. Kim, Y.K.; Shin, J.S.; Nahm, M.H. NOD-like receptors in infection, immunity, and diseases. Yonsei Med. J. 2016, 57, 5-14. [CrossRef]

215. Latz, E.; Xiao, T.S.; Stutz, A. Activation and regulation of the inflammasomes. Nat. Rev. Immunol. 2013, 13, 397-411. [CrossRef]

216. Du, P.; Fan, B.; Han, H.; Zhen, J.; Shang, J.; Wang, X.; Li, X.; Shi, W.; Tang, W.; Bao, C.; et al. NOD2 promotes renal injury by exacerbating inflammation and podocyte insulin resistance in diabetic nephropathy. Kidney Int. 2013, 84, 265-276. [CrossRef]

217. Huang, W.; Gou, F.; Long, Y.; Li, Y.; Feng, H.; Zhang, Q.; Gao, C.; Chen, G.; Xu, Y. High Glucose and Lipopolysaccharide Activate NOD1- RICK-NF-кB Inflammatory Signaling in Mesangial Cells. Exp. Clin. Endocrinol. Diabetes 2016, 124, 512-517. [CrossRef]

218. Shang, J.; Zhang, Y.; Jiang, Y.; Li, Z.; Duan, Y.; Wang, L.; Xiao, J.; Zhao, Z. NOD2 promotes endothelial-to-mesenchymal transition of glomerular endothelial cells via MEK/ERK signaling pathway in diabetic nephropathy. Biochem. Biophys. Res. Commun. 2017, 484, 435-441. [CrossRef]

219. Shang, J.; Wan, Q.; Wang, X.; Duan, Y.; Wang, Z.; Wei, X.; Zhang, Y.; Wang, H.; Wang, R.; Yi, F. Identification of NOD2 as a novel target of RNA-binding protein HuR: Evidence from NADPH oxidase-mediated HuR signaling in diabetic nephropathy. Free Radic. Biol. Med. 2015, 79, 217-227. [CrossRef]

220. Wen, H.; Ting, J.P.-Y.; O'Neill, L.A.J. A role for the NLRP3 inflammasome in metabolic diseases-did Warburg miss inflammation? Nat. Immunol. 2012, 13, 352-357. [CrossRef]

221. Wang, S.; Zhao, X.; Yang, S.; Chen, B.; Shi, J. Salidroside alleviates high glucose-induced oxidative stress and extracellular matrix accumulation in rat glomerular mesangial cells by the TXNIP-NLRP3 inflammasome pathway. Chem. Biol. Interact. 2017, 278, 48-53. [CrossRef] [PubMed] 
222. Fu, Y.; Wu, N.; Zhao, D. Function of NLRP3 in the pathogenesis and development of diabetic nephropathy. Med. Sci. Monit. 2017, 23, 3878-3884. [CrossRef] [PubMed]

223. Song, S.; Qiu, D.; Luo, F.; Wei, J.; Wu, M.; Wu, H.; Du, C.; Du, Y.; Ren, Y.; Chen, N.; et al. Knockdown of NLRP3 alleviates high glucose or TGFB1-induced EMT in human renal tubular cells. J. Mol. Endocrinol. 2018, 61, 101-113. [CrossRef] [PubMed]

224. Bhattacharjee, C.K.; Paine, S.K.; Mahanta, J.; Borphukan, S.; Borah, P.K. Expression of inflammasome complex mRNA and its targeted microRNA in type 2 diabetes mellitus: A possible predictor of the severity of diabetic nephropathy. J. Diabetes 2019, 11, 90-92. [CrossRef] [PubMed]

225. Wu, M.; Han, W.; Song, S.; Du, Y.; Liu, C.; Chen, N.; Wu, H.; Shi, Y.; Duan, H. NLRP3 deficiency ameliorates renal inflammation and fibrosis in diabetic mice. Mol. Cell. Endocrinol. 2018, 478, 115-125. [CrossRef] [PubMed]

226. Wang, C.; Pan, Y.; Zhang, Q.-Y.; Wang, F.-M.; Kong, L.-D. Quercetin and allopurinol ameliorate kidney injury in STZ-treated rats with regulation of renal NLRP3 inflammasome activation and lipid accumulation. PLoS ONE 2012, 7, e38285. [CrossRef]

227. Samra, Y.A.; Said, H.S.; Elsherbiny, N.M.; Liou, G.I.; El-Shishtawy, M.M.; Eissa, L.A. Cepharanthine and Piperine ameliorate diabetic nephropathy in rats: Role of NF-kB and NLRP3 inflammasome. Life Sci. 2016, 157, 187-199. [CrossRef]

228. Wang, Y.; Yu, B.; Wang, L.; Yang, M.; Xia, Z.; Wei, W.; Zhang, F.; Yuan, X. Pioglitazone ameliorates glomerular NLRP3 inflammasome activation in apolipoprotein E knockout mice with diabetes mellitus. PLoS ONE 2017, 12, e0181248. [CrossRef]

229. Zhang, C.; Zhu, X.; Li, L.; Ma, T.; Shi, M.; Yang, Y.; Fan, Q. A small molecule inhibitor MCC950 ameliorates kidney injury in diabetic nephropathy by inhibiting NLRP3 inflammasome activation. Diabetes Metab. Syndr. Obes. Targets Ther. 2019, 12, 1297-1309. [CrossRef]

230. Shahzad, K.; Bock, F.; Al-Dabet, M.M.; Gadi, I.; Kohli, S.; Nazir, S.; Ghosh, S.; Ranjan, S.; Wang, H.; Madhusudhan, T.; et al. Caspase-1, but not caspase-3, promotes diabetic nephropathy. J. Am. Soc. Nephrol. 2016, 27, 2270-2275. [CrossRef]

231. Lin, M.; Tang, S.C.W. Toll-like receptors: Sensing and reacting to diabetic injury in the kidney. Nephrol. Dial. Transplant. 2014, 29, 746-754. [CrossRef] [PubMed]

232. Lin, M.; Yiu, W.H.; Li, R.X.; Wu, H.J.; Wong, D.W.L.; Chan, L.Y.Y.; Leung, J.C.K.; Lai, K.N.; Tang, S.C.W. The TLR4 antagonist CRX-526 protects against advanced diabetic nephropathy. Kidney Int. 2013, 83, 887-900. [CrossRef] [PubMed]

233. Cha, J.J.; Hyun, Y.Y.; Lee, M.H.; Kim, J.E.; Nam, D.H.; Song, H.K.; Kang, Y.S.; Lee, J.E.; Kim, H.W.; Han, J.Y.; et al. Renal protective effects of toll-like receptor 4 signaling blockade in type 2 diabetic mice. Endocrinology 2013, 154, 2144-2155. [CrossRef]

234. Huang, X.; Liu, G.; Guo, J.; Su, Z.Q. The PI3K/AKT pathway in obesity and type 2 diabetes. Int. J. Biol. Sci. 2018, 14, 1483-1496. [CrossRef]

235. Maffei, A.; Lembo, G.; Carnevale, D. PI3Kinases in Diabetes Mellitus and Its Related Complications. Int. J. Mol. Sci. 2018, 19, 4098. [CrossRef]

236. Lieberthal, W.; Levine, J.S. The role of the mammalian target of rapamycin (mTOR) in renal disease. J. Am. Soc. Nephrol. 2009, 20, 2493-2502. [CrossRef]

237. Lee, C.-H.; Inoki, K.; Guan, K.-L. mTOR pathway as a target in tissue hypertrophy. Annu. Rev. Pharmacol. Toxicol. 2007, 47, 443-467. [CrossRef]

238. Inoki, K.; Mori, H.; Wang, J.; Suzuki, T.; Hong, S.; Yoshida, S.; Blattner, S.M.; Ikenoue, T.; Rüegg, M.A.; Hall, M.N.; et al. mTORC1 activation in podocytes is a critical step in the development of diabetic nephropathy in mice. J. Clin. Investig. 2011, 121, 2181-2196. [CrossRef]

239. Yang, Y.; Wang, J.; Qin, L.; Shou, Z.; Zhao, J.; Wang, H.; Chen, Y.; Chen, J. Rapamycin prevents early steps of the development of diabetic nephropathy in rats. Am. J. Nephrol. 2007, 27, 495-502. [CrossRef]

240. Song, Y.; Liu, W.; Tang, K.; Zang, J.; Li, D.; Gao, H. Mangiferin Alleviates Renal Interstitial Fibrosis in Streptozotocin-Induced Diabetic Mice through Regulating the PTEN/PI3K/Akt Signaling Pathway. J. Diabetes Res. 2020, 9481720. [CrossRef]

241. Zhang, Y.; Wang, Y.; Luo, M.; Xu, F.; Lu, Y.; Zhou, X.; Cui, W.; Miao, L. Elabela protects against podocyte injury in mice with streptozocin-induced diabetes by associating with the PI3K/Akt/mTOR pathway. Peptides 2019, 114, 29-37. [CrossRef] [PubMed] 
242. Wang, D.; Jin, M.; Zhao, X.; Zhao, T.; Lin, W.; He, Z.; Fan, M.; Jin, W.; Zhou, J.; Jin, L.; et al. FGF1 $\Delta H B S$ ameliorates chronic kidney disease via PI3K/AKT mediated suppression of oxidative stress and inflammation. Cell Death Dis. 2019, 10, 464. [CrossRef] [PubMed]

243. Sadi, G.; Şahin, G.; Bostanc1, A. Modulation of Renal Insulin Signaling Pathway and Antioxidant Enzymes with Streptozotocin-Induced Diabetes: Effects of Resveratrol. Medicina (Kaunas) 2018, 55, 3. [CrossRef]

244. Zhang, J.; Zhao, X.; Zhu, H.; Wang, J.; Ma, J.; Gu, M. Apigenin Protects Against Renal Tubular Epithelial Cell Injury and Oxidative Stress by High Glucose via Regulation of NF-E2-Related Factor 2 (Nrf2) Pathway. Med. Sci. Monit. 2019, 25, 5280-5288. [CrossRef]

245. Jing, D.; Bai, H.; Yin, S. Renoprotective effects of emodin against diabetic nephropathy in rat models are mediated via PI3K/Akt/GSK-3 $\beta$ and Bax/caspase-3 signaling pathways. Exp. Ther. Med. 2017, 14, 5163-5169. [CrossRef]

246. Song, N.; Thaiss, F.; Guo, L. NFkB and Kidney Injury. Front. Immunol. 2019, 10, 815. [CrossRef]

247. Suryavanshi, S.V.; Kulkarni, Y.A. NF- $\kappa \beta$ : A Potential Target in the Management of Vascular Complications of Diabetes. Front. Pharmacol. 2017, 8, 798. [CrossRef]

248. Kim, J.E.; Lee, M.H.; Nam, D.H.; Song, H.K.; Kang, Y.S.; Lee, J.E.; Kim, H.W.; Cha, J.J.; Hyun, Y.Y.; Han, S.Y.; et al. Celastrol, an NF- $\mathrm{kB}$ inhibitor, improves insulin resistance and attenuates renal injury in $\mathrm{db} / \mathrm{db}$ mice. PLoS ONE 2013, 8, e62068. [CrossRef]

249. Sun, Y.; Peng, R.; Peng, H.; Liu, H.; Wen, L.; Wu, T.; Yi, H.; Li, A.; Zhang, Z. miR-451 suppresses the NF-kappaB-mediated proinflammatory molecules expression through inhibiting LMP7 in diabetic nephropathy. Mol. Cell. Endocrinol. 2016, 433, 75-86. [CrossRef]

250. Liu, W.; Zhang, X.; Liu, P.; Shen, X.; Lan, T.; Li, W.; Jiang, Q.; Xie, X.; Huang, H. Effects of berberine on matrix accumulation and NF-kappa B signal pathway in alloxan-induced diabetic mice with renal injury. Eur. J. Pharmacol. 2010, 638, 150-155. [CrossRef]

251. Ahmed, S.; Mundhe, N.; Borgohain, M.; Chowdhury, L.; Kwatra, M.; Bolshette, N.; Ahmed, A.; Lahkar, M. Diosmin Modulates the NF-kB Signal Transduction Pathways and Downregulation of Various Oxidative Stress Markers in Alloxan-Induced Diabetic Nephropathy. Inflammation 2016, 39, 1783-1797. [CrossRef]

252. Kolati, S.R.; Kasala, E.R.; Bodduluru, L.N.; Mahareddy, J.R.; Uppulapu, S.K.; Gogoi, R.; Barua, C.C.; Lahkar, M. BAY 11-7082 ameliorates diabetic nephropathy by attenuating hyperglycemia-mediated oxidative stress and renal inflammation via NF-кB pathway. Environ. Toxicol. Pharmacol. 2015, 39, 690-699. [CrossRef]

253. López-Franco, O.; Suzuki, Y.; Sanjuán, G.; Blanco, J.; Hernández-Vargas, P.; Yo, Y.; Kopp, J.; Egido, J.; Gómez-Guerrero, C. Nuclear factor- $\mathrm{kB}$ inhibitors as potential novel anti-inflammatory agents for the treatment of immune glomerulonephritis. Am. J. Pathol. 2002, 161, 1497-1505. [CrossRef]

254. Oguiza, A.; Recio, C.; Lazaro, I.; Mallavia, B.; Blanco, J.; Egido, J.; Gomez-Guerrero, C. Peptide-based inhibition of $\mathrm{I} \kappa \mathrm{B}$ kinase/nuclear factor- $\mathrm{\kappa} B$ pathway protects against diabetes-associated nephropathy and atherosclerosis in a mouse model of type 1 diabetes. Diabetologia 2015, 58, 1656-1667. [CrossRef]

255. Elsherbiny, N.M.; El-Sherbiny, M.; Said, E. Amelioration of experimentally induced diabetic nephropathy and renal damage by nilotinib. J. Physiol. Biochem. 2015, 71, 635-648. [CrossRef]

256. Lazaro, I.; Oguiza, A.; Recio, C.; Mallavia, B.; Madrigal-Matute, J.; Blanco, J.; Egido, J.; Martin-Ventura, J.L.; Gomez-Guerrero, C. Targeting HSP90 ameliorates nephropathy and atherosclerosis through suppression of NF- $\mathrm{BB}$ and STAT signaling pathways in diabetic mice. Diabetes 2015, 64, 3600-3613. [CrossRef]

257. Villarino, A.V.; Kanno, Y.; O'Shea, J.J. Mechanisms and consequences of Jak-STAT signaling in the immune system. Nat. Immunol. 2017, 18, 374-384. [CrossRef]

258. Morris, R.; Kershaw, N.J.; Babon, J.J. The molecular details of cytokine signaling via the JAK/STAT pathway. Protein Sci. 2018, 27, 1984-2009. [CrossRef]

259. Stark, G.R.; Darnell, J.E. The JAK-STAT pathway at twenty. Immunity 2012, 36, 503-514. [CrossRef]

260. Cheon, H.J.; Yang, J.; Stark, G.R. The functions of signal transducers and activators of transcriptions 1 and 3 as cytokine-inducible proteins. J. Interf. Cytokine Res. 2011, 31, 33-40. [CrossRef]

261. Lopez-Sanz, L.; Bernal, S.; Recio, C.; Lazaro, I.; Oguiza, A.; Melgar, A.; Jimenez-Castilla, L.; Egido, J.; Gomez-Guerrero, C. SOCS1-targeted therapy ameliorates renal and vascular oxidative stress in diabetes via STAT1 and PI3K inhibition. Lab. Investig. 2018, 98, 1276-1290. [CrossRef] [PubMed]

262. Zhou, Y.; Lv, C.; Wu, C.; Chen, F.; Shao, Y.; Wang, Q. Suppressor of cytokine signaling (SOCS) 2 attenuates renal lesions in rats with diabetic nephropathy. Acta Histochem. 2014, 116, 981-988. [CrossRef] [PubMed] 
263. Thomas, S.J.; Snowden, J.A.; Zeidler, M.P.; Danson, S.J. The role of JAK/STAT signalling in the pathogenesis, prognosis and treatment of solid tumours. Br. J. Cancer 2015, 113, 365-371. [CrossRef] [PubMed]

264. Marrero, M.B.; Banes-berceli, A.K.; Stern, D.M.; Eaton, D.C.; Mario, B.; Douglas, C. Role of the JAK/STAT signaling pathway in diabetic nephropathy. Am. J. Physiol.-Renal Physiol. 2006, 290, 762-768. [CrossRef]

265. Brosius, F.C.; Tuttle, K.R.; Kretzler, M. JAK inhibition in the treatment of diabetic kidney disease. Diabetologia 2016, 59, 1624-1627. [CrossRef]

266. Ortiz-Muñoz, G.; Lopez-Parra, V.; Lopez-Franco, O.; Fernandez-Vizarra, P.; Mallavia, B.; Flores, C.; Sanz, A.; Blanco, J.; Mezzano, S.; Ortiz, A.; et al. Suppressors of cytokine signaling abrogate diabetic nephropathy. J. Am. Soc. Nephrol. 2010, 21, 763-772. [CrossRef]

267. Sun, M.-Y.; Wang, S.-J.; Li, X.-Q.; Shen, Y.-L.; Lu, J.-R.; Tian, X.-H.; Rahman, K.; Zhang, L.-J.; Nian, H.; Zhang, H. CXCL6 Promotes Renal Interstitial Fibrosis in Diabetic Nephropathy by Activating JAK/STAT3 Signaling Pathway. Front. Pharmacol. 2019, 10, 224. [CrossRef]

268. Hashimoto, R.; Kakigi, R.; Miyamoto, Y.; Nakamura, K.; Itoh, S.; Daida, H.; Okada, T.; Katoh, Y. JAK-STAT-dependent regulation of scavenger receptors in LPS-activated murine macrophages. Eur. J. Pharmacol. 2020, 871, 172940. [CrossRef]

269. Banes, A.K.; Shaw, S.; Jenkins, J.; Redd, H.; Amiri, F.; Pollock, D.M.; Marrero, M.B. Angiotensin II blockade prevents hyperglycemia-induced activation of JAK and STAT proteins in diabetic rat kidney glomeruli. Am. J. Physiol. Renal Physiol. 2004, 286, F653-F659. [CrossRef]

270. Zhang, H.; Nair, V.; Saha, J.; Atkins, K.B.; Hodgin, J.B.; Saunders, T.L.; Myers, M.G.; Werner, T.; Kretzler, M.; Brosius, F.C. Podocyte-specific JAK2 overexpression worsens diabetic kidney disease in mice. Kidney Int. 2017, 92, 909-921. [CrossRef]

271. Dieter, B.P.; Meek, R.L.; Anderberg, R.J.; Cooney, S.K.; Bergin, J.L.; Zhang, H.; Nair, V.; Kretzler, M.; Brosius, F.C.; Tuttle, K.R. Serum amyloid A and Janus kinase 2 in a mouse model of diabetic kidney disease. PLoS ONE 2019, 14, e0211555. [CrossRef] [PubMed]

272. Zheng, C.; Huang, L.; Luo, W.; Yu, W.; Hu, X.; Guan, X.; Cai, Y.; Zou, C.; Yin, H.; Xu, Z.; et al. Inhibition of STAT3 in tubular epithelial cells prevents kidney fibrosis and nephropathy in STZ-induced diabetic mice. Cell Death Dis. 2019, 10, 848. [CrossRef] [PubMed]

273. Said, E.; Zaitone, S.A.; Eldosoky, M.; Elsherbiny, N.M. Nifuroxazide, a STAT3 inhibitor, mitigates inflammatory burden and protects against diabetes-induced nephropathy in rats. Chem. Biol. Interact. 2018, 281, 111-120. [CrossRef] [PubMed]

274. Liu, R.; Zhong, Y.; Li, X.; Chen, H.; Jim, B.; Zhou, M.-M.; Chuang, P.Y.; He, J.C. Role of transcription factor acetylation in diabetic kidney disease. Diabetes 2014, 63, 2440-2453. [CrossRef] [PubMed]

275. Banerjee, S.; Biehl, A.; Gadina, M.; Hasni, S.; Schwartz, D.M. JAK-STAT Signaling as a Target for Inflammatory and Autoimmune Diseases: Current and Future Prospects. Drugs 2017, 77, 521-546. [CrossRef]

276. Tuttle, K.R.; Brosius, F.C.; Adler, S.G.; Kretzler, M.; Mehta, R.L.; Tumlin, J.A.; Tanaka, Y.; Haneda, M.; Liu, J.; Silk, M.E.; et al. JAK1/JAK2 inhibition by baricitinib in diabetic kidney disease: Results from a Phase 2 randomized controlled clinical trial. Nephrol. Dial. Transplant. 2018, 33, 1950-1959. [CrossRef]

277. Ortiz-Muñoz, G.; Martin-Ventura, J.L.; Hernandez-Vargas, P.; Mallavia, B.; Lopez-Parra, V.; Lopez-Franco, O.; Muñoz-Garcia, B.; Fernandez-Vizarra, P.; Ortega, L.; Egido, J.; et al. Suppressors of cytokine signaling modulate JAK/STAT-mediated cell responses during atherosclerosis. Arterioscler. Thromb. Vasc. Biol. 2009, 29, 525-531. [CrossRef]

278. Yoshimura, A.; Suzuki, M.; Sakaguchi, R.; Hanada, T.; Yasukawa, H. SOCS, Inflammation, and Autoimmunity. Front. Immunol. 2012, 3, 20. [CrossRef]

279. Fosgerau, K.; Hoffmann, T. Peptide therapeutics: Current status and future directions. Drug Discov. Today 2015, 20, 122-128. [CrossRef]

280. Recio, C.; Oguiza, A.; Lazaro, I.; Mallavia, B.; Egido, J.; Gomez-Guerrero, C. Suppressor of cytokine signaling 1-derived peptide inhibits janus kinase/signal transducers and activators of transcription pathway and improves inflammation and atherosclerosis in diabetic mice. Arterioscler. Thromb. Vasc. Biol. 2014, 34, 1953-1960. [CrossRef]

281. Hernández, C.; Bogdanov, P.; Gómez-Guerrero, C.; Sampedro, J.; Solà-Adell, C.; Espejo, C.; García-Ramírez, M.; Prieto, I.; Egido, J.; Simó, R. SOCS1-derived peptide administered by eye drops prevents retinal neuroinflammation and vascular leakage in experimental diabetes. Int. J. Mol. Sci. 2019, 20, 3615. [CrossRef] [PubMed] 
282. Shi, Y.; Du, C.; Zhang, Y.; Ren, Y.; Hao, J.; Zhao, S.; Yao, F.; Duan, H. Suppressor of cytokine signaling-1 ameliorates expression of MCP-1 in diabetic nephropathy. Am. J. Nephrol. 2010, 31, 380-388. [CrossRef] [PubMed]

283. Recio, C.; Lazaro, I.; Oguiza, A.; Lopez-Sanz, L.; Bernal, S.; Blanco, J.; Egido, J.; Gomez-Guerrero, C. Suppressor of Cytokine Signaling-1 Peptidomimetic Limits Progression of Diabetic Nephropathy. J. Am. Soc. Nephrol. 2017, 28, 575-585. [CrossRef] [PubMed]

284. Pieper, G.M. Riaz-ul-Haq Activation of nuclear factor- $k b$ in cultured endothelial cells by increased glucose concentration: Prevention by calphostin C. J. Cardiovasc. Pharmacol. 1997, 30, 528-532. [CrossRef] [PubMed]

285. Ohshiro, Y.; Ma, R.C.; Yasuda, Y.; Hiraoka-Yamamoto, J.; Clermont, A.C.; Isshiki, K.; Yagi, K.; Arikawa, E.; Kern, T.S.; King, G.L. Reduction of diabetes-induced oxidative stress, fibrotic cytokine expression, and renal dysfunction in protein kinase C $\beta$-null mice. Diabetes 2006, 55, 3112-3120. [CrossRef] [PubMed]

286. Mima, A.; Kitada, M.; Geraldes, P.; Li, Q.; Matsumoto, M.; Mizutani, K.; Qi, W.; Li, C.; Leitges, M.; Rask-Madsen, C.; et al. Glomerular VEGF resistance induced by PKC $\delta / \mathrm{SHP}-1$ activation and contribution to diabetic nephropathy. FASEB J. 2012, 26, 2963-2974. [CrossRef]

287. Al-Onazi, A.S.; Al-Rasheed, N.M.; Attia, H.A.; Al-Rasheed, N.M.; Ahmed, R.M.; Al-Amin, M.A.; Poizat, C. Ruboxistaurin attenuates diabetic nephropathy via modulation of TGF- $\beta 1 / \mathrm{Smad}$ and GRAP pathways. J. Pharm. Pharmacol. 2016, 68, 219-232. [CrossRef]

288. Wang, Z.B.; Zhang, S.; Li, Y.; Wang, R.M.; Tong, L.C.; Wang, Y.; Liu, W.Y.; Su, D.F.; Tu, Y.; Zhang, L.C.; et al. LY333531, a PKC $\beta$ inhibitor, attenuates glomerular endothelial cell apoptosis in the early stage of mouse diabetic nephropathy via down-regulating swiprosin-1. Acta Pharmacol. Sin. 2017, 38, 1009-1023. [CrossRef]

289. Tuttle, K.R.; McGill, J.B.; Bastyr, E.J.; Poi, K.K.; Shahri, N.; Anderson, P.W. Effect of ruboxistaurin on albuminuria and estimated GFR in people with diabetic peripheral neuropathy: Results from a randomized trial. Am. J. Kidney Dis. 2015, 65, 634-636. [CrossRef]

290. Guerrero-Hue, M.; Farre-Alins, V.; Palomino-Antolin, A.; Parada, E.; Rubio-Navarro, A.; Egido, J.; Egea, J.; Moreno, J.A. Targeting Nrf2 in Protection Against Renal Disease. Curr. Med. Chem. 2017, 24, 3583-3605. [CrossRef]

291. Cui, W.; Min, X.; Xu, X.; Du, B.; Luo, P. Role of Nuclear Factor Erythroid 2-Related Factor 2 in Diabetic Nephropathy. J. Diabetes Res. 2017, 2017, 3797802. [CrossRef] [PubMed]

292. Yagishita, Y.; Fukutomi, T.; Sugawara, A.; Kawamura, H.; Takahashi, T.; Pi, J.; Uruno, A.; Yamamoto, M. Nrf2 protects pancreatic $\beta$-cells from oxidative and nitrosative stress in diabetic model mice. Diabetes 2014, 63, 605-618. [CrossRef] [PubMed]

293. Li, H.; Zhang, L.; Wang, F.; Shi, Y.; Ren, Y.; Liu, Q.; Cao, Y.; Duan, H. Attenuation of glomerular injury in diabetic mice with tert- butylhydroquinone through nuclear factor erythroid 2-related factor 2-dependent antioxidant gene activation. Am. J. Nephrol. 2011, 33, 289-297. [CrossRef] [PubMed]

294. Huang, Z.; Mou, Y.; Xu, X.; Zhao, D.; Lai, Y.; Xu, Y.; Chen, C.; Li, P.; Peng, S.; Tian, J.; et al. Novel Derivative of Bardoxolone Methyl Improves Safety for the Treatment of Diabetic Nephropathy. J. Med. Chem. 2017, 60, 8847-8857. [CrossRef] [PubMed]

295. Cui, W.; Bai, Y.; Miao, X.; Luo, P.; Chen, Q.; Tan, Y.; Rane, M.J.; Miao, L.; Cai, L. Prevention of Diabetic Nephropathy by Sulforaphane: Possible Role of Nrf2 Upregulation and Activation. Oxid. Med. Cell. Longev. 2012, 2012. [CrossRef] [PubMed]

296. Chen, Y.-J.; Kong, L.; Tang, Z.-Z.; Zhang, Y.-M.; Liu, Y.; Wang, T.-Y.; Liu, Y.-W. Hesperetin ameliorates diabetic nephropathy in rats by activating Nrf2/ARE/glyoxalase 1 pathway. Biomed. Pharmacother. 2019, 111, 1166-1175. [CrossRef]

297. Yang, Z.-J.; Wang, H.-R.; Wang, Y.-I.; Zhai, Z.-H.; Wang, L.-W.; Li, L.; Zhang, C.; Tang, L. Myricetin Attenuated Diabetes-Associated Kidney Injuries and Dysfunction via Regulating Nuclear Factor (Erythroid Derived 2)-Like 2 and Nuclear Factor-kB Signaling. Front. Pharmacol. 2019, 10, 647. [CrossRef]

298. Song, J.; Zhang, H.; Sun, Y.; Guo, R.; Zhong, D.; Xu, R.; Song, M. Omentin-1 protects renal function of mice with type 2 diabetic nephropathy via regulating miR-27a-Nrf2/Keap1 axis. Biomed. Pharmacother. 2018, 107, 440-446. [CrossRef]

299. Soetikno, V.; Sari, F.R.; Sukumaran, V.; Lakshmanan, A.P.; Harima, M.; Suzuki, K.; Kawachi, H.; Watanabe, K. Curcumin decreases renal triglyceride accumulation through AMPK-SREBP signaling pathway in streptozotocin-induced type 1 diabetic rats. J. Nutr. Biochem. 2013, 24, 796-802. [CrossRef] 
300. Jiménez-Osorio, A.S.; García-Niño, W.R.; González-Reyes, S.; Álvarez-Mejía, A.E.; Guerra-León, S.; Salazar-Segovia, J.; Falcón, I.; Montes de Oca-Solano, H.; Madero, M.; Pedraza-Chaverri, J. The Effect of Dietary Supplementation With Curcumin on Redox Status and Nrf2 Activation in Patients With Nondiabetic or Diabetic Proteinuric Chronic Kidney Disease: A Pilot Study. J. Ren. Nutr. 2016, 26, 237-244. [CrossRef]

301. Yang, H.; Xu, W.; Zhou, Z.; Liu, J.; Li, X.; Chen, L.; Weng, J.; Yu, Z. Curcumin attenuates urinary excretion of albumin in type II diabetic patients with enhancing nuclear factor erythroid-derived 2-like 2 (Nrf2) system and repressing inflammatory signaling efficacies. Exp. Clin. Endocrinol. Diabetes 2015, 123, 360-367. [CrossRef] [PubMed]

302. Pergola, P.E.; Krauth, M.; Huff, J.W.; Ferguson, D.A.; Ruiz, S.; Meyer, C.J.; Warnock, D.G. Effect of bardoxolone methyl on kidney function in patients with T2D and stage 3b-4 CKD. Am. J. Nephrol. 2011, 33, 469-476. [CrossRef]

303. Pergola, P.E.; Raskin, P.; Toto, R.D.; Meyer, C.J.; Huff, J.W.; Grossman, E.B.; Krauth, M.; Ruiz, S.; Audhya, P.; Christ-Schmidt, H.; et al. Bardoxolone methyl and kidney function in CKD with type 2 diabetes. N. Engl. J. Med. 2011, 365, 327-336. [CrossRef] [PubMed]

304. De Zeeuw, D.; Akizawa, T.; Audhya, P.; Bakris, G.L.; Chin, M.; Christ-Schmidt, H.; Goldsberry, A.; Houser, M.; Krauth, M.; Lambers Heerspink, H.J.; et al. Bardoxolone methyl in type 2 diabetes and stage 4 chronic kidney disease. N. Engl. J. Med. 2013, 369, 2492-2503. [CrossRef] [PubMed]

305. Chin, M.P.; Bakris, G.L.; Block, G.A.; Chertow, G.M.; Goldsberry, A.; Inker, L.A.; Heerspink, H.J.L.; O'Grady, M.; Pergola, P.E.; Wanner, C.; et al. Bardoxolone Methyl Improves Kidney Function in Patients with Chronic Kidney Disease Stage 4 and Type 2 Diabetes: Post-Hoc Analyses from Bardoxolone Methyl Evaluation in Patients with Chronic Kidney Disease and Type 2 Diabetes Study. Am. J. Nephrol. 2018, 47, 40-47. [CrossRef]

306. Komers, R.; Lindsley, J.N.; Oyama, T.T.; Cohen, D.M.; Anderson, S. Renal p38 MAP kinase activity in experimental diabetes. Lab. Investig. 2007, 87, 548-558. [CrossRef]

307. Adhikary, L.; Chow, F.; Nikolic-Paterson, D.J.; Stambe, C.; Dowling, J.; Atkins, R.C.; Tesch, G.H. Abnormal p38 mitogen-activated protein kinase signalling in human and experimental diabetic nephropathy. Diabetologia 2004, 47, 1210-1222. [CrossRef]

308. Tesch, G.H.; Ma, F.Y.; Han, Y.; Liles, J.T.; Breckenridge, D.G.; Nikolic-Paterson, D.J. ASK1 inhibitor halts progression of diabetic nephropathy in Nos3-deficient mice. Diabetes 2015, 64, 3903-3913. [CrossRef]

309. Liles, J.T.; Corkey, B.K.; Notte, G.T.; Budas, G.R.; Lansdon, E.B.; Hinojosa-Kirschenbaum, F.; Badal, S.S.; Lee, M.; Schultz, B.E.; Wise, S.; et al. ASK1 contributes to fibrosis and dysfunction in models of kidney disease. J. Clin. Investig. 2018, 128, 4485-4500. [CrossRef]

310. Cha, J.J.; Kang, Y.S.; Hyun, Y.Y.; Han, S.Y.; Jee, Y.H.; Han, K.H.; Han, J.Y.; Cha, D.R. Sulodexide improves renal function through reduction of vascular endothelial growth factor in type 2 diabetic rats. Life Sci. 2013, 92, 1118-1124. [CrossRef]

311. Vallon, V.; Thomson, S.C. Targeting renal glucose reabsorption to treat hyperglycaemia: The pleiotropic effects of SGLT2 inhibition. Diabetologia 2017, 60, 215-225. [CrossRef] [PubMed]

312. Wanner, C.; Inzucchi, S.E.; Lachin, J.M.; Fitchett, D.; Von Eynatten, M.; Mattheus, M.; Johansen, O.E.; Woerle, H.J.; Broedl, U.C.; Zinman, B.; et al. Empagliflozin and progression of kidney disease in type 2 diabetes. N. Engl. J. Med. 2016, 375, 323-334. [CrossRef] [PubMed]

313. Han, J.H.; Oh, T.J.; Lee, G.; Maeng, H.J.; Lee, D.H.; Kim, K.M.; Choi, S.H.; Jang, H.C.; Lee, H.S.; Park, K.S.; et al. The beneficial effects of empagliflozin, an SGLT2 inhibitor, on atherosclerosis in ApoE -/- mice fed a western diet. Diabetologia 2017, 60, 364-376. [CrossRef] [PubMed]

314. Terami, N.; Ogawa, D.; Tachibana, H.; Hatanaka, T.; Wada, J.; Nakatsuka, A.; Eguchi, J.; Horiguchi, C.S.; Nishii, N.; Yamada, H.; et al. Long-term treatment with the sodium glucose cotransporter 2 inhibitor, dapagliflozin, ameliorates glucose homeostasis and diabetic nephropathy in $\mathrm{db} / \mathrm{db}$ mice. PLoS ONE 2014, 9, e100777. [CrossRef] [PubMed]

315. Lin, B.; Koibuchi, N.; Hasegawa, Y.; Sueta, D.; Toyama, K.; Uekawa, K.; Ma, M.; Nakagawa, T.; Kusaka, H.; Kim-Mitsuyama, S. Glycemic control with empagliflozin, a novel selective SGLT2 inhibitor, ameliorates cardiovascular injury and cognitive dysfunction in obese and type 2 diabetic mice. Cardiovasc. Diabetol. 2014, 13, 148. [CrossRef] [PubMed] 
316. Heerspink, H.J.L.; Perco, P.; Mulder, S.; Leierer, J.; Hansen, M.K.; Heinzel, A.; Mayer, G. Canagliflozin reduces inflammation and fibrosis biomarkers: A potential mechanism of action for beneficial effects of SGLT2 inhibitors in diabetic kidney disease. Diabetologia 2019, 62, 1154-1166. [CrossRef]

317. Davis, H.; Jones Briscoe, V.; Dumbadze, S.; Davis, S.N. Using DPP-4 inhibitors to modulate beta cell function in type 1 diabetes and in the treatment of diabetic kidney disease. Expert Opin. Investig. Drugs 2019, 28, 377-388. [CrossRef]

318. Liu, W.; Yu, J.; Yan, Q.; Wang, L.; Li, N.; Xiong, W. Meta-analysis of the benefit of sitagliptin treatment in patients with type 2 diabetes complicated with incipient nephropathy. Exp. Ther. Med. 2018, 16, 2545-2553. [CrossRef]

319. Marques, C.; Gonçalves, A.; Pereira, P.M.R.; Almeida, D.; Martins, B.; Fontes-Ribeiro, C.; Reis, F.; Fernandes, R. The dipeptidyl peptidase 4 inhibitor sitagliptin improves oxidative stress and ameliorates glomerular lesions in a rat model of type 1 diabetes. Life Sci. 2019, 234, 116738. [CrossRef]

320. Wang, J.; Hu, L.; Chen, Y.; Fu, T.; Jiang, T.; Jiang, A.; You, X. Sitagliptin improves renal function in diabetic nephropathy in male Sprague Dawley rats through upregulating heme oxygenase-1 expression. Endocrine 2019, 63, 70-78. [CrossRef]

321. Tanaka, Y.; Kume, S.; Chin-Kanasaki, M.; Araki, H.; Araki, S.-I.; Ugi, S.; Sugaya, T.; Uzu, T.; Maegawa, H. Renoprotective effect of DPP-4 inhibitors against free fatty acid-bound albumin-induced renal proximal tubular cell injury. Biochem. Biophys. Res. Commun. 2016, 470, 539-545. [CrossRef] [PubMed]

322. Cheng, S.; Li, L.; Song, C.; Jin, H.; Ma, S.; Kang, P. Sitagliptin relieves diabetic nephropathy fibrosis via the MAPK/ERK signaling pathway. Minerva Endocrinol. 2020. [CrossRef]

323. Baggio, L.L.; Drucker, D.J. Biology of Incretins: GLP-1 and GIP. Gastroenterology 2007, 132, $2131-2157$. [CrossRef] [PubMed]

324. Ninčević, V.; Kolarić, T.O.; Roguljić, H.; Kizivat, T.; Smolić, M.; Curčić, I.B. Renal benefits of SGLT 2 inhibitors and GLP-1 receptor agonists: Evidence supporting a paradigm shift in the medical management of type 2 diabetes. Int. J. Mol. Sci. 2019, 20, 5831. [CrossRef] [PubMed]

325. Dieter, B.P.; Alicic, R.Z.; Tuttle, K.R. GLP-1 receptor agonists in diabetic kidney disease: From the patient-side to the bench-side. Am. J. Physiol. Ren. Physiol. 2018, 315, F1519-F1525. [CrossRef]

326. Moellmann, J.; Klinkhammer, B.M.; Onstein, J.; Stöhr, R.; Jankowski, V.; Jankowski, J.; Lebherz, C.; Tacke, F.; Marx, N.; Boor, P.; et al. Glucagon-Like Peptide 1 and Its Cleavage Products Are Renoprotective in Murine Diabetic Nephropathy. Diabetes 2018, 67, 2410-2419. [CrossRef]

327. Kang, Z.; Zeng, J.; Zhang, T.; Lin, S.; Gao, J.; Jiang, C.; Fan, R.; Yin, D. Hyperglycemia induces NF-kB activation and MCP-1 expression via downregulating GLP-1R expression in rat mesangial cells: Inhibition by metformin. Cell Biol. Int. 2019, 43, 940-953. [CrossRef]

328. Hendarto, H.; Inoguchi, T.; Maeda, Y.; Ikeda, N.; Zheng, J.; Takei, R.; Yokomizo, H.; Hirata, E.; Sonoda, N.; Takayanagi, R. GLP-1 analog liraglutide protects against oxidative stress and albuminuria in streptozotocin-induced diabetic rats via protein kinase A-mediated inhibition of renal NAD(P)H oxidases. Metabolism 2012, 61, 1422-1434. [CrossRef]

329. Yin, Q.H.; Zhang, R.; Li, L.; Wang, Y.T.; Liu, J.P.; Zhang, J.; Bai, L.; Cheng, J.Q.; Fu, P.; Liu, F. Exendin-4 ameliorates lipotoxicity-induced glomerular endothelial cell injury by improving ABC transporter A1mediated cholesterol efflux in diabetic apoE knockout mice. J. Biol. Chem. 2016, 291, 26487-26501. [CrossRef]

330. Yin, W.; Xu, S.; Wang, Z.; Liu, H.; Peng, L.; Fang, Q.; Deng, T.; Zhang, W.; Lou, J. Recombinant human GLP-1(rhGLP-1) alleviating renal tubulointestitial injury in diabetic STZ-induced rats. Biochem. Biophys. Res. Commun. 2018, 495, 793-800. [CrossRef]

331. Tuttle, K.R.; Lakshmanan, M.C.; Rayner, B.; Busch, R.S.; Zimmermann, A.G.; Woodward, D.B.; Botros, F.T. Dulaglutide versus insulin glargine in patients with type 2 diabetes and moderate-to-severe chronic kidney disease (AWARD-7): A multicentre, open-label, randomised trial. Lancet Diabetes Endocrinol. 2018, 6, 605-617. [CrossRef]

332. De Boer, I.H. Liraglutide and Renal Outcomes in Type 2 Diabetes. N. Engl. J. Med. 2017, 377, 2198. [PubMed]

333. Marso, S.P.; Bain, S.C.; Consoli, A.; Eliaschewitz, F.G.; Jodar, E.; Leiter, L.A.; Lingvay, I.; Rosenstock, J.; Seufert, J.; Warren, M.L.; et al. Semaglutide and cardiovascular outcomes in patients with type 2 diabetes. N. Engl. J. Med. 2016, 375, 1834-1844. [CrossRef] [PubMed] 
334. Pfeffer, M.A.; Claggett, B.; Diaz, R.; Dickstein, K.; Gerstein, H.C.; Køber, L.V.; Lawson, F.C.; Ping, L.; Wei, X.; Lewis, E.F.; et al. Lixisenatide in patients with type 2 diabetes and acute coronary syndrome. N. Engl. J. Med. 2015, 373, 2247-2257. [CrossRef] [PubMed]

335. Campion, C.G.; Sanchez-Ferras, O.; Batchu, S.N. Potential role of serum and urinary biomarkers in diagnosis and prognosis of diabetic nephropathy. Can. J. Kidney Health Dis. 2017, 4, 2054358117705371. [CrossRef] [PubMed]

336. Tvarijonaviciute, A.; Castillo, C.; Ceron, J.J.; Martinez-Subiela, S.; Tecles, F.; López-Jornet, P. Leptin and NGF in saliva of patients with diabetes mellitus type 2: A pilot study. J. Oral Pathol. Med. 2017, 46, 853-855. [CrossRef]

337. Srinivasan, M.; Meadows, M.L.; Maxwell, L. Assessment of Salivary Adipokines Resistin, Visfatin, and Ghrelin as Type 2 Diabetes Mellitus Biomarkers. Biochem. Res. Int. 2018, 7463796. [CrossRef]

(C) 2020 by the authors. Licensee MDPI, Basel, Switzerland. This article is an open access article distributed under the terms and conditions of the Creative Commons Attribution (CC BY) license (http://creativecommons.org/licenses/by/4.0/). 